Andrews University

Digital Commons @ Andrews University

Professional Dissertations DMin

Graduate Research

1999

\title{
The Development of a Worship Education Program
}

Neal Maynard Matson

Andrews University

Follow this and additional works at: https://digitalcommons.andrews.edu/dmin

Part of the Practical Theology Commons

\section{Recommended Citation}

Matson, Neal Maynard, "The Development of a Worship Education Program" (1999). Professional Dissertations DMin. 506.

https://dx.doi.org/10.32597/dmin/506

https://digitalcommons.andrews.edu/dmin/506

This Project Report is brought to you for free and open access by the Graduate Research at Digital Commons @ Andrews University. It has been accepted for inclusion in Professional Dissertations DMin by an authorized administrator of Digital Commons @ Andrews University. For more information, please contact repository@andrews.edu. 


\section{ABSTRACT}

\section{THE DEVELOPMENT OF A WORSHIP EDUCATION PROGRAM}

$$
\text { by }
$$

\section{Neal Maynard Matson}

Adviser: Robert M. Johnston 


\section{ABSTRACT OF GRADUATE STUDENT RESEARCH \\ Dissertation}

Andrews University

Seventh-day Adventist Theological Seminary

\section{Title: THE DEVELOPMENT OF A WORSHIP EDUCATION PROGRAM}

Name of researcher: Neal Maynard Matson

Name and degree of faculty adviser: Robert M. Johnston, Ph.D.

Date completed: August 1999

\section{Problem}

The Seventh-day Adventist Church has never developed a theology of worship. Therefore, the members are unacquainted with the biblical principles of worship. Too often their patterns of worship renewal are often influenced more by sociological factors and methodology than by theology. There is a definite need of a worship education program for the Seventh-day Adventist Church.

\section{Method}

A syllabus was produced for a seminar presentation on the biblical principles of worship. The seminar was presented over a thirteen-week period. Worship patterns of the College Place Village Church were discussed. A survey employed to discover 
members' worship knowledge and preferences was distributed at the beginning and the close of the seminar.

Results

A comparison of attitudes and knowledge at the completion of the seminar revealed that there is widespread ignorance on the principles of worship among the members of the Seventh-day Adventist Church. The seminar also revealed that although there may be an increase of knowledge on the subject of worship, strong attitudes remain on what is proper for worship.

\section{Conclusions}

The members of the Seventh-day Adventist Church can be educated in biblical principles of worship. However, there must be a stronger emphasis by the leadership of the denomination to give the topic of worship the emphasis that it deserves. 
Andrews University

. Seventh-day Adventist Theological Seminary

.,.

THE DEVELOPMENT OF A WORSHIP EDUCATION PROGRAM

\author{
A Dissertation \\ Presented in Partial Fulfillment \\ of the Requirements for the Degree \\ Doctor of Ministry
}

by

Neal Maynard Matson

August 1999 



\section{THE DEVELOPMENT OF A WORSHIP EDUCATION PROGRAM}

A dissertation

presented in partial fulfillment

of the requirements for the degree

Doctor of Ministry

by

Neal Maynard Matson

APPROTOALÄBY THE COMMITTEE:

perting Adviser

Robert M Johnston

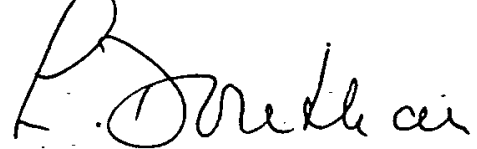

Lilianne Doukhan

Barry Gane -

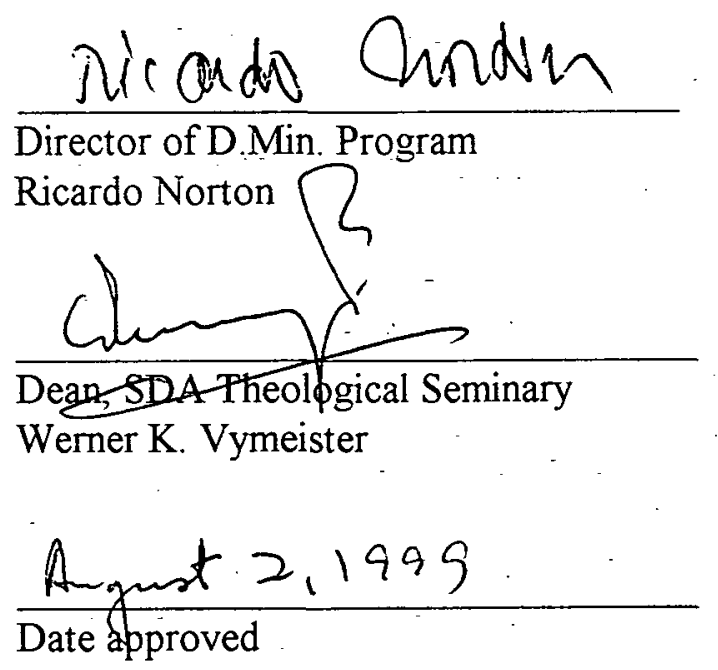




\section{TABLE OF CONTENTS}

\section{Chapter}

1. INTRODUCTION TO THE PROJECT $\ldots \ldots \ldots \ldots \ldots \ldots \ldots \ldots \ldots \ldots$

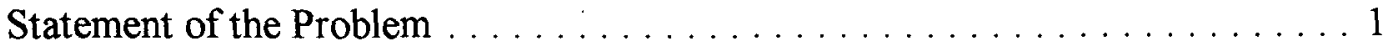

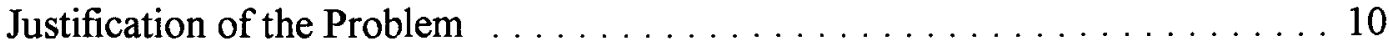

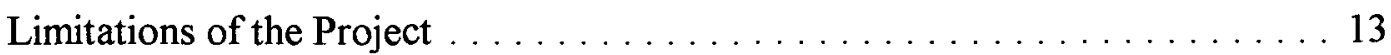

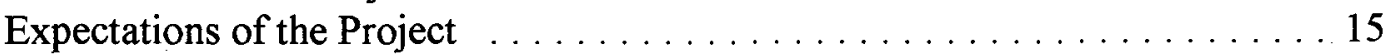

2. BIBLICAL PATTERNS OF WORSHIP $\ldots \ldots \ldots \ldots \ldots \ldots \ldots$

The Creatures Worship Their Creator $\ldots \ldots \ldots \ldots \ldots \ldots \ldots \ldots$

Worship and the Psalms . . . . . . . . . . . . . . . . . . . . 19

Worship Practices of the New Testament . . . . . . . . . . . . . 21

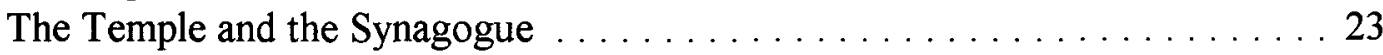

The Temple ............................ 24

The Origin of the Synagogue . . . . . . . . . . . . . . . . . 25

New Testament Scriptural Passages of Worship . . . . . . . . . . . . . . 29

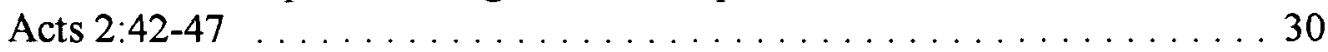

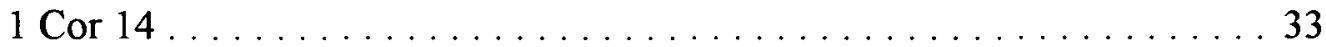

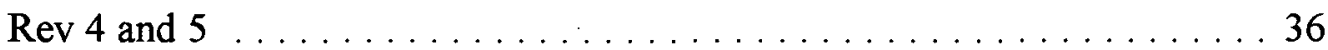

3. A THEOLOGY OF CHRISTIAN WORSHIP . . . . . . . . . . . . . . 39

The Need for Theology, not Methodology . . . . . . . . . . . . . . . 39

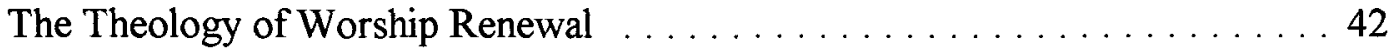

Revelation and Response ....................... 44

The Work of the Holy Spirit . . . . . . . . . . . . . . . . . 54

Summary of the Theology of Worship . . . . . . . . . . . . 56

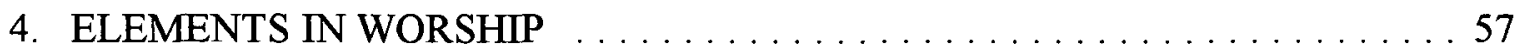

The Place in Worship . . . . . . . . . . . . . . . . . . . 59

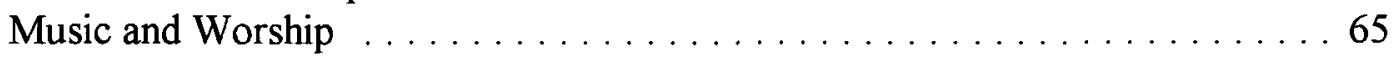

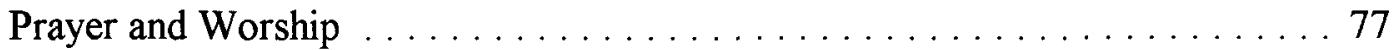


The Bible and Worship . . . . . . . . . . . . . . . . . . 80

The Sermon in Worship . . . . . . . . . . . . . . . . . 83

5. IMPLEMENTATION OF THE PROJECT . . . . . . . . . . . . . . . . . 89

The Development of the Worship Education Seminar . . . . . . . . . . . 90

The Development of the Order of Service . . . . . . . . . . . . 93

6. CONCLUSIONS .............................. 100

SDAs Need to Develop a Theology of Worship . . . . . . . . . . . 100

SDAs Must Develop a Systematic Worship Education Program . . . . . . . 102

The Need for Planning by Worship Leaders . . . . . . . . . . . . . 103

The Need for Preparation by the Congregation . . . . . . . . . . . . . . 104

Appendix

1. WORSHIP SERVICE SURVEY $\ldots \ldots \ldots \ldots \ldots \ldots \ldots \ldots \ldots$

2. WORSHIP EDUCATION SYLLABUS $\ldots \ldots \ldots \ldots \ldots \ldots \ldots \ldots \ldots$

BIBLIOGRAPHY . . . . . . . . . . . . . . . . . . . . . 151

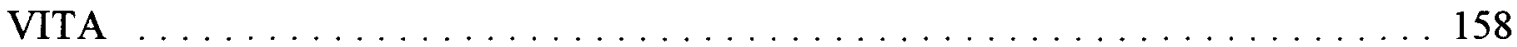




\section{CHAPTER 1}

\section{INTRODUCTION TO THE PROJECT}

\section{Statement of the Problem}

The 1980s presented the members of the Seventh-day Adventist ${ }^{1}$ Church in North America with an unfortunate crisis. During that time many brothers and sisters within the denomination became agitated, argumentative, and openly hostile toward one another on the subject of the proper manner to worship God.

Not only was this controversy within the SDA Church unfortunate, but it was also to a large degree unnecessary. The denomination could have avoided most of the emotional displays of temper and criticism by its members if only it had paid closer attention to the "worship wars"2 which have been common throughout many eras of church history. They could have especially benefitted from lessons other denominations have learned in recent generations as these different churches faced the issue of how God can best be worshiped. But an ignorance of ecclesiastical history worked against the

${ }^{1}$ Hereafter "Seventh-day Adventist" will be replaced by "SDA."

${ }^{2}$ Marva J. Dawn, Reaching Out Without Dumbing Down: A Theology of Worship for the Turn-of-the-Century Culture (Grand Rapids, MI: William B. Eerdmans Pub. Co., 1995), 3. 
denomination as members dialogued over a very important issue for the Christian community.

It was during the decades of the 1950s and 1960s that the Christian Church experienced a period of what was termed "liturgical revival." That was an era of major unrest, dissension, and controversy among mainline Protestant denominations and Roman Catholics over the issue of worship. During this time period major revisions regularly occurred in the patterns of worship. New hymnals and other worship materials were introduced and changes were made in the order of service. These revised worship patterns emerged so repeatedly that it was difficult for most of the congregations which were caught up in this liturgical renewal to adjust to them. The revisions were too frequent and too numerous. ${ }^{2}$

However, as was previously stated, change in the patterns of worship is not a new phenomenon which is exclusive to our modern times. Throughout the history of Christianity each generation has adapted its own method of praising God to its peculiar time and surroundings. Experimentation in worship forms should be expected. As James F. White ${ }^{3}$ states:

New forms of worship have appeared in every century as peoples and cultures changed. All twenty centuries of the Christian era have been centuries of experimentation in worship. Twentieth-century liturgical experimentation must be

\section{${ }^{1}$ C. Raymond Holmes, Sing a New Song (Berrien Springs, MI: Andrews} University Press, 1984), 3.

${ }^{2}$ Ibid.

${ }^{3}$ James F. White is a twentieth-century liturgical scholar and author, and should not be confused with James S. White, who was one of the founders of the SDA Church. 
seen in this context as the continuation of a well-established pattern of change rather than as the beginning of it. ${ }^{1}$

This era of liturgical reform in the 1960s affected two of the largest sectors of Christianity. For Roman Catholics the transformation in the worship service was immediate and dramatic--the major changes affected the entire atmosphere of their liturgical structure: "The Second Vatican Council enacted the Constitution on the Sacred Liturgy in December, 1963... The immediate practical effect of the Constitution was the translation of the existing Roman rite into various vernacular languages."2 With the Mass now in the common language of the local congregation, the services became understandable to all who participated.

Changes in the mainline Protestant world were also dramatic. Many viewed this liturgical renewal as the time for the church to recover the legacy of the reforming fathers of the Protestant movement. Their new goal became to recapture the spirit of the Reformation and, in some cases, even the language. As James F. White says,

It was a time, we may remember, of the recovery of Reformation patterns of worship. Both the legacy of neo-orthodox theology and the contributions of serious historical scholarship had produced a new fascination with the liturgies of the Reformation. There was much talk of recovering our heritage in worship, and this usually meant a new appreciation of Reformation liturgies from Martin Luther's Formula Missae of 1523 to John Knox's The Forme of Prayers of 1556. For Methodists it might be extended as far as John Wesley's Sunday Service of 1784, and some even felt that Philip Schaff's (and others) Order of Worship of 1866 deserved a second look. The process of liturgical revision was moving in the direction of recovering practices promoted by the sixteenth-century Reformers. While the Methodist Book of Worship was being revised prior to 1964, it was

${ }^{1}$ James F. White, New Forms of Worship (Nashville: Abingdon Press, 1971), 57.

${ }^{2}$ Cheslyn Jones, Geoffrey Wainright, and Edward Yarnold, eds., The Study of Liturgy (New York: Oxford University Press, 1978), 140. 
seriously proposed that the communion order be a return to Thomas Cranmer's 1549 service, leapfrogging over the subsequent revisions. . . . The Methodist revisers, like all others of that time, retained the familiar sixteenth-century English prose. $^{1}$

But this attempt to recapture the spirit of Luther, Knox, and Wesley also soon experienced revisions. A major emphasis during the 1960 s became not only to return to the worship practices of the Reformation, but also to travel the time line of history back further to the birth of the Christian Church. Even forsaking the advances of the Reformation, worshipers wanted to use the church of the first century as their model. As James F. White continues, "Within five years such procedures had been forsaken altogether by denominations revising their service books. If they looked to the past it was not so much to the Reformation as to the early church they turned."2

The ultimate result of the "revival" was that the Protestant churches lost much of what had distinguished them from the Roman Catholic Church. To some it seemed that the Reformation had regressed. To quote from Norval Pease, an SDA liturgical scholar:

We saw the pendulum swing from the spontaneity of early church worship to the formalism of medieval worship and back [because of the Reformation] to the spontaneity of reformed worship. We shall watch that pendulum as it swings past way back in the direction of formalism. ... First, the Communion service is replacing the sermon as the central item in the order of worship. Second, the ecclesiastical calendar is being restored. Third, vestments are being worn by a growing percentage of the clergy. Fourth, the pulpit is being moved "from a central position to one side, placing new focus on the communion table." Thus we

${ }^{1}$ James F. White, New Forms of Worship, 15, 16.

${ }^{2}$ Ibid., 16. 
see the accomplishments of the Protestant Reformation being nullified, one after another. $^{1}$

During the liturgical battles of the 1960s SDAs were largely unaffected by the turmoil in the Christian world. "We have not been greatly influenced by the liturgical revival,"2 Pease wrote in 1967 . However, instead of being pro-active and educating the church membership in biblical principles of worship, the subject was virtually ignored until the "Celebration"3 movement arose in the 1980s. When the SDA community was finally confronted with different approaches to worship, the reaction was typical to controversies of this type. Individuals took sides and spoke heated words as the denomination was plunged into a debate over patterns of worship, as others had done previously.

Now, as the dawn of the twenty-first century approaches, the issue of worship hardly stirs much discussion within SDA churches, but not because the issue has been settled. Unfortunately, the denomination has resumed the practice of basically ignoring the topic of worship. The crises have passed and other subjects dominate discussion among members and leaders, such as women's ordination, the doctrine of the inspiration of the Scriptures, and, most recently, a congregationalist approach to church organization. 38.

${ }^{1}$ Norval F. Pease, And Worship Him (Nashville: Southern Pub. Assn., 1967), 37,

${ }^{2}$ Ibid., 44.

${ }^{3}$ To many SDAs the word "Celebration" is synonymous with attempts to "modernize" the worship service through usage of liturgical practices borrowed predominantly from other denominations. Such practices can include praise songs instead of hymns, words projected on and sung from a screen instead of the hymnal, the use of applause to show favor instead of saying "Amen," guitars and drums used for music instead of organs, etc. 
Alden Thompson describes the typical pattern of how a church reacts when confronted with a controversial subject. He says, "Given the crises in the church, the members were ready to listen. But crises pass. The church goes to sleep again. Then we ripen for another crisis."

SDAs are not alone in their denomination's ignorance of worship principles. Unfortunately, this lack of knowledge on the subject of worship is a continuing problem in other Protestant churches as well. Paul Hoon comments upon this illiteracy by saying, "The fact is that ignorance of the meaning of worship is so widespread among the laity of free-church Protestantism as to be virtually disabling."2

But it is especially tragic that SDAs, a denomination claiming to be based upon and knowledgeable about the Bible, should experience such a crisis. SDA theology presents its church as the one divinely ordained to carry the last message of warning to the world as is found in the Three Angels' Messages of Rev 14. Yet, as Holmes comments, the central theme in each of these messages is "a call to worship," a concept which is often overlooked. In fact, as Holmes further states, "Worship is the issue in the great controversy between God and Satan."

'Alden Thompson, Inspiration (Hagerstown, MD: Review and Herald Pub. Assn., 1991), 13.

${ }^{2}$ Paul W. Hoon, The Integrity of Worship (Nashville: Abingdon Press, 1971), 30.

${ }^{3}$ Holmes, Sing a New Song, 7.

${ }^{4} \mathrm{C}$. Raymond Holmes, "Searching for Genuine Adventist Worship," Affirm 5, no. 2 (Fall 1991): 29. 
In Rev 14 the first angel commands the reader to "worship him who made heaven and earth, the sea, and the fountains of waters" (Rev 14:7 KJV). ${ }^{1}$ The second angel warns that "Babylon [the false system of worship] is fallen"(Rev 14:8 KJV). And the message of the third angel shows that allegiance to the apostate beast power means to worship it instead of God. The result of this worship is to receive the dreaded "Mark of the Beast." "If any man worship the beast and his image, and receive his mark in his forehead or in his hand, the same shall drink of the wine of the wrath of God" (Rev 14:9, $10 \mathrm{KJV})$. The emphasis on who is worshiped and why He or "it" is worshiped is central to the foundation of the SDA Church. It is a concept that must be enforced into the minds and practices of SDAs.

There are three basic reasons why the SDA denomination has had difficulty over the issue of worship. First, the study of this topic is charged with emotion, and in most congregations it must be approached with caution.

Very often individual members have definite opinions about which forms are proper in the service of worshiping God. For many, anything beyond the boundaries of their own paradigms is unacceptable. Any modification of the worship experience is viewed as blasphemy, and pastors who try innovative and creative worship concepts are subject to suspicion and criticism. Change is often too traumatic and painful for most Christians to handle.

${ }^{1}$ Quoted Bible references are from the New International Version (NIV) unless otherwise indicated. 
What part do culture and personality play in how church members worship God? How do Christians choose between innovation and tradition, between old forms of worship and new, between the emotional and the intellectual? What is "right" and what is "wrong" for Christian worship services? What part do geographical, ethnic, and cultural backgrounds factor into how church members worship God? These questions must be addressed by the denomination and each congregation. But the answers must come from biblical and theological bases.

A second difficulty in studying the topic of worship arises from human nature. There are those within every denomination who wish for the church to mandate everything to them and make all activities of the world-wide church uniform. There are those within the SDA denomination who point to the "official" order of service in the denomination's Church Manual ${ }^{1}$ as the standard from which there can be no deviation. To them all is written in stone.

Paul Hoon terms this attitude as "liturgical authoritarianism," and describes it by saying, "We like someone to make decisions for us, or more likely, we rather enjoy making decisions for other people." ${ }^{2}$ These types of individuals dictate their ideas to others as if divinely inspired.

The third reason this topic is divisive in the SDA community is a lack of knowledge. Very little emphasis has been placed on worship education in the majority of

${ }^{1}$ Seventh-day Adventist Church Manual, $15^{\text {th }}$ ed. (Hagerstown, MD: Review and Herald Pub. Assn., 1995), 65, 66.

${ }^{2}$ Hoon, 26. 
churches within the SDA denomination, and the study of this topic has not been high on the list of priorities for most members.

This is well illustrated by a visit to an Adventist Book Center, a retail outlet run by local conferences to offer SDA publications to the community. Recent trips to "ABCs"

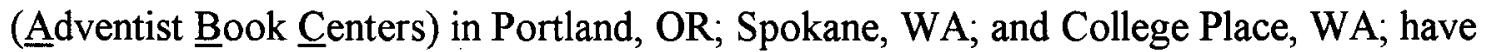
produced an interesting fact. There an observer will find numerous volumes presenting topics such as spiritual growth, devotional aids, the Sabbath, the Second Coming of Christ, books about interpretation of the prophetic writings of Daniel and Revelation, and separate sections for the writings of Ellen $\mathrm{G}$. White, one of the founders of the SDA Church whom the members consider inspired as their prophet from God.

But what of worship? How important is this topic for the contemporary SDA Church? At the time of this project only three books about worship written by SDA authors have been published and circulated. In 1967 And Worship Him by Norval F. Pease became the first study into worship principles by an SDA author. And the time frame in which it appears indicates it was a reaction to the liturgical revolution taking place in the Christian world. This volume is currently not available in print.

In 1984, seventeen years after Pease's work was published, it was expanded upon by C. Raymond Holmes's presentation of Sing a New Song, which is still available through Andrews University Press. Both books are "must" reading for SDA leaders of worship to better understand SDA thought and perspective on the subject.

The most recent offering on this subject is The Challenge of the Empty Pew published in 1992 as a result of Linford Lee Martin's doctoral project at Andrews 
University. ${ }^{1}$ While not widely circulated, it is available through the North American Division of SDAs.

If what David Watson says is true, that "the primary task of the church is to worship God,"2 Christians are missing something very important if they neglect the study of this subject. Worship is the reason humanity exists--to give God His ultimate worth. The core of worship is to respond in loving obedience to the self-revelation of God. This is the basis of Christianity, and everything in the Christian experience springs from worship. As James F. White says,

We are forced, at least, to question the importance of worship for the Christian life. Does worship merit the expenditure of as much time and talent as preparation for it now seems to demand? Our answer is "yes" because of the conviction that worship is at the very center of the church's mission. Evangelism, social action, nurture, education, all grow out of worship like the petals from the center of a flower. $^{3}$

\section{$\underline{\text { Justification of the Project }}$}

The purpose of this project was to design a program of worship education for a local congregation based upon theological and biblical principles. From this a study guide for congregational participation was developed to present these principles. The final result

${ }^{1}$ Linford Lee Martin, The Challenge of the Empty Pew: A Pastor's Guide to Improved Church Attendance (Lincoln, NE: Church Resources Distribution Center, 1992), ix.

${ }^{2}$ David Watson, $\underline{\text { B Believe in the Church (Grand Rapids, MI: William B. Eerdmans }}$ Pub. Co., 1978), 179.

${ }^{3}$ James F. White, New Forms of Worship, 51. 
will be to implement an order of service which will enable the church family to experience the corporate worship of their God.

Personal investigation of literature on this subject, numerous discussions with administrative leaders and fellow pastors, and personal contacts with members have convinced me that the SDA Church needs a renewed emphasis on the subject of worship. For too long members have been guided primarily by tradition and are largely unacquainted with what the Bible teaches about how Christians are to approach their God in worship.

Congregations must emphasize that each worship service is a special opportunity for Christians to offer praise and glory to God for who He is and what He has done. The worship of the congregation must demonstrate that God is given His ultimate worth, for He is the Creator and, through Jesus Christ, the Redeemer.

But SDAs must also demonstrate in their worship the doctrines which members believe designate the distinctive message the church offers the world in contemporary times. As Holmes says, "There are three distinctive doctrines which ought to be illustrated liturgically in every Adventist church's worship service: the Sabbath, the heavenly ministry of Christ, and the second advent of Christ."' If these three teachings are distinctive for SDAs their worship should reflect these teachings whenever members meet together as corporate bodies.

It is necessary to understand that worship services do not just happen on Sabbath morning--intensive planning is necessary before the eleven o'clock hour. If plans for

${ }^{1}$ Holmes, Sing a New Song, 16. 
worship are neglected, the result can be chaos and the congregation is deprived of a full and meaningful worship experience.

As a ministerial student I vividly remember an assignment for a college homiletics course when I spoke for the worship service in the church I attended as a very young child. The lack of planning for the service was appalling. Just before the ministers were to appear on the platform before the waiting congregation, the two elders who were the leaders of worship engaged in an argument. Their pointed discussion centered around who would offer the morning prayer and who would call for the offering. While this incident may be considered by some as extreme, sadly, situations are not much different in many other churches which have been observed.

Personal conversations with conference presidents indicate that this lack of planning for the weekly worship services is one of the greatest deficiencies in the SDA churches today. Several years ago the Upper Columbia Conference indicated a deep concern about this situation, and administrators suggested this topic would be included in seminars available for the training of pastors and members. Unfortunately, this has not yet happened.

The correct concept of worship is central in understanding humanity's relationship with God. As redeemed people it is essential for Christians to express love and devotion to God, responding in worship for His great gift of salvation received through Jesus Christ. To worship God means to dedicate life to Him in joyful service.

My personal experience indicates that church members would benefit in a program of education in the components of worship, such as music, prayer, the purpose of he 
sermon, and Scripture. When used in corporate worship each of these elements reminds worshipers of how God has revealed to humanity an aspect of His love, especially His love revealed through the life of Christ. True worship happens when humanity responds in loving obedience to God's divine revelation.

Furthermore, the order of service must be structured in a way that the congregation will be led each week into a celebration of the presence of God. That is the core of the worship experience.

\section{Limitations of the Project}

This study is limited in its demographics to the congregation of the College Place Village SDA Church in College Place, WA. So the reader can understand the dynamic of the church that this paper is based upon, some comments are necessary to become acquainted with this congregation.

The College Place Village Church, or "Village" as it is more commonly known, was organized in 1892, the same year Walla Walla College was founded. This church served the basic needs of College Place until 1948 when a separate church, the Walla Walla College Church, was founded specifically for the faculty and students of the college. In 1968 the Village Church moved to its current location.

The Village Church is the largest SDA congregation in the Pacific Northwest. On January 1, 1999, its membership was officially listed at 1,921 members. A survey of the records shows that the congregation is almost equally divided into three age categories: those under thirty years of age, those between the ages of thirty and sixty, and those 
beyond sixty. Even though officially almost equal in these areas, a Sabbath morning worship service will indicate a higher number of older people in attendance, and many consider it to be an "older person's church."

Five pastors currently serve the congregation. In addition to the senior pastor, ministers are designated to lead in the youth ministries, family life, and visitation. I currently serve as pastor of evangelism. None of the pastors are women, although the church has employed two women part-time to be Bible instructors and to lead out in ministry to the women in the congregation.

The mood is conservative in matters of church organization. There are no women elders who serve the congregation, and the median age of the church board at the time of this project is over fifty. Many retired pastors are members of this congregation.

The conservative attitudes are also reflected in the church's worship patterns. Although at times praise songs are included for worship, the predominant music is from the hymnal. A choir composed of members of the congregation is an integral part of the worship service, and while a variety of styles for musical specials is presented, the music is normally traditional instead of contemporary. The pew Bible is the New King James Version, and the standard King James Version is the most popular among the congregation. Applause is very rare at the Village Church.

I do not intend to portray the Village Church in a negative way--it is a very warm, loving, and wonderful congregation. However, it is also very tradition-oriented, and that presents difficulties for fulfilling the mission of the church. Christianity's mandate is to spread the gospel to the community in ways that will attract a society that stands on the 
edge of the twenty-first century. The congregation is facing some major issues concerning church organization and mission in the near future. How the members deal with these issues will make a major impact on the church.

\section{Expectations from the Project}

It is expected that the members, through education in the principles of worship, will celebrate a new sense of God's presence during the worship service. Members need to catch a deeper sense of the holiness of God.

It is expected that the order of service will be structured to lead the congregation directly into a celebration of God in the worship service.

I personally expect to increase my personal skill as a leader of worship for my congregation.

I also expect to increase my personal skill and knowledge in the subject, enabling me to be a better teacher of worship for any congregation that I might serve. 


\section{CHAPTER 2}

\section{BIBLICAL PATTERNS OF WORSHIP}

The entire Bible is a book of worship. From its pages we receive a picture of a God whose power to create and re-create makes Him the object of love and adoration from the entire universe. God alone is worthy of worship. His self-revelation as Creator and as Redeemer evokes a response of love from His creatures. That response is called "worship."

This chapter will address the topic of worship in the Bible. It should be obvious to the reader that an exhaustive study of this subject is beyond the space limitations of this paper. However, there are several sections of the Scriptures, both the Old and New Testaments, that bring specific insights into the character of the God who is deserving of worship.

\section{The Creatures Worship Their Creator}

All worship begins with a revelation of the power of God. The first glimpses recorded of that power given in the Scriptures are the creation story in Genesis. There, by the authority, majesty, and grace of God, a world was called into existence. The Creator was pleased with His creation--the Bible records that His work was "very good" (Gen 1:31). God was satisfied with the work of His hands. 
The active process of creation took a period of six days, culminating with the union of the lives of Adam and Eve. ${ }^{1}$. After God finished His work He completed the seven-day cycle by instituting a Sabbath, a day of rest for Himself and all that He had made.

The Bible does not give any detail about what was done that first "seventh day" of rest. But it seems appropriate that this time would be used by God to introduce Himself in a deeper and more detailed manner to His brand-new creatures. Adam and Eve needed to become acquainted with their Creator. Ellen G. White comments about the purpose of the Sabbath:

After resting upon the seventh day, God sanctified it, or set it apart, as a day of rest for man. Following the example of the Creator, man was to rest upon this sacred day, that as he should look upon the heavens and the earth, he might reflect upon God's great work of creation; and that as he should behold the evidences of God's wisdom and goodness, his heart might be filled with love and reverence for His maker. ${ }^{2}$

God knew that a regular time of reverence and devotion to Him by His creatures was essential for them. That time is worship.

This weekly cycle of the Sabbath was given for the good of both the Creator and

His children. Ellen $\mathrm{G}$. White continues:

God saw that a Sabbath was essential for man, even in Paradise. He needed to lay aside his own interests and pursuits for one day of the seven, that he might more fully contemplate the works of God and meditate upon His power and goodness. He needed a Sabbath to remind him more vividly of God and to awaken

${ }^{1}$ Gen 2:21-24.

${ }^{2}$ Ellen G. White, Patriarchs and Prophets (Mountain View, CA: Pacific Press Pub. Assn., 1958), 47. 
gratitude because all that he enjoyed and possessed came from the beneficent hand of the Creator. ${ }^{1}$

God had provided a way that humanity could worship the Creator and weekly experience the joy of intimate communication with Him.

Even after sin entered the world, the Sabbath remained a time to honor the Creator. However, because of the independence that sin brings, centering upon humanity rather than God, the Sabbath lost most of its meaning and was neglected. In His instructions to Israel from Sinai, God commanded His people to "remember" the Sabbath day. ${ }^{2}$ The Sabbath became not only a day to remember creation, but also became a symbol of sanctification for a redeemed people. ${ }^{3}$

The Sabbath is the greatest continual sign that reminds humans of their Creator/creature relationship with God. As to its importance, Ellen G. White says, "Had the Sabbath been universally kept, man's thoughts and affections would have been led to the Creator as the object of reverence and worship, and there never would have been an idolater, an atheist, or an infidel."4

If the Sabbath was originally given as a reminder for the creatures of God to remember their Creator in worship and devotion, it is just as vital for a blessing for humanity today. Christians must discover the beauty and meaning that are given by that

${ }^{1}$ Ibid., 48.

${ }^{2}$ Exod 20:8

${ }^{3}$ Exod 31:12-17

${ }^{4}$ Ellen G. White, The Great Controversy (Mountain View, CA: Pacific Press Pub. Assn., 1911), 438. 
time of rest with the One who is their Creator and Redeemer. They must be consistently reminded of the words of the Psalmist, "Come, let us bow down in worship, let us kneel before the LORD our Maker; for he is our God and we are the people of his pasture, the flock under his care" (Ps 95:6, 7).

\section{Worship and the Psalms}

The act of worship is primarily an expression of an experience with God. For those who take the Bible as their authoritative source of information of how God has demonstrated His creative and redemptive powers throughout the history of this world, it is a record of human encounter with the divine. There is no better account of God's activities and actions for His creatures than is found in the Psalms. And there is also no better description of human response than what is contained in this book.

James F. White gives a good summary of what a Bible student will find in an examination of Psalms. He states: "The psalms articulate our wonder and marvel (and occasionally our despair) at what God has done. Sometimes they are deeply and intimately personal; at other times they are a recapitulation of salvation history."1

The Psalms express the complete spectrum of human emotions in encountering God. The grandeur of His creative power is expressed in the words, "The heavens declare the glory of God; the skies proclaim the work of his hands" (Ps 19:1). There is the declaration of satisfaction and peace, summed up in the exclamation "The LorD is my shepherd, I shall not be in want" (Ps 23:1). The comfort of being in the safety of God's

${ }^{1}$ James F. White, Introduction to Christian Worship, rev. ed. (Nashville: Abingdon Press, 1990), 159. 
care is described as, "God is our refuge and strength, an ever-present help in trouble" (Ps 46:1). And the joy of worship is illustrated by saying, "Come, let us sing for joy to the LoRD; let us shout aloud to the Rock of our salvation" (Ps 95:1).

There are also cries of despair and anguish. For example, "Hear my cry for mercy as I call to you for help" (Ps 28:2). At times a feeling of rejection by God is expressed: "Why, O LoRD, do you reject me and hide your face from me?" (Ps 88:14). And the emotion of Jesus on the cross was plainly felt when He cried, "My God, my God, why have you forsaken me? (Ps 22:1).

For sinners in need of salvation, perhaps no other Psalm carries the impact of David's chronicle of his illicit affair with Bathsheba. Recorded are David's pleas for mercy and cleansing, ${ }^{1}$ acknowledgment of his $\sin ^{2}{ }^{2}$ and a desire to truly experience the joy that comes from a salvation experience with God. ${ }^{3}$ Perhaps the most beautiful prayer of a penitent heart is found in the sentence, "Create in me a pure heart, O God, and renew a steadfast spirit within me" (Ps 51:10).

Since the Psalms so poignantly portray the human experience, it is no wonder that they have played an important part in worship. Franklin Segler illustrates how the Psalms have been used in worship:

The Psalms are rich in personal worship; however, personal does not necessarily mean individual or private, for many of the Psalms were written to be used in public worship. The Psalter has always been the most used and best-loved

${ }^{1}$ Ps $51: 1,2$.

${ }^{2} \mathrm{Ps} 51: 3-6$

${ }^{3} \mathrm{Ps} 51: 12$. 
book of the Old Testament. The Psalms have been the foundation of Christian hymnody. ${ }^{1}$

Whether the words are spoken or sung, the messages of the Psalms have had a great impact in the worship of the church, and they will continue to express the love and devotion that God's creatures express for their creator.

\section{Worship Practices of the New Testament}

Although worship throughout the Bible always gives praise and honor to God, the New Testament focuses upon the worship of the Savior, Jesus Christ. Because of His sacrifice and the devotion of the Christians to Him and His saving ministry, the New Testament Church was established to spread the good news of His salvation and of His soon-coming to take His redeemed to heaven. ${ }^{2}$

As a Christian denomination, SDAs uphold the Bible as the primary authority in their consideration of religious topics. A study of Christian worship in the New Testament era, therefore, would require a survey of the worship practices of the New Testament church as listed in the Bible.

But therein lies a large problem, since the New Testament does not give a major outline of worship practices in the apostolic church. As Robert Webber notes, "There is no single highly developed statement on worship in the New Testament." ${ }^{\text {3 }}$ And Robert

${ }^{1}$ Franklin M. Segler, Christian Worship: Its Theology and Practice, rev. ed. (Nashville: Broadman \& Holman Publishers, 1996), 20.

${ }^{2}$ Acts 2 .

${ }^{3}$ Robert E. Webber, Worship Old and New, rev. ed. (Grand Rapids, MI: Zondervan Pub. House, 1994), 41. 
Rayburn concurs with that statement:

It must be pointed out at the outset that what we know of the worship practices of the earliest Christians is quite limited. The New Testament gives us only the barest glimpses into the services of worship conducted by the apostles. We have no suggestions of the order of services which are mentioned in the Scriptures and we have no real description of the liturgy used. ${ }^{1}$

However, we should not bemoan the fact that the Bible gives us no definite

liturgical pattern which we can discern or copy. Norval Pease agrees:

True, that church [the New Testament church] has left us no liturgy. That in itself is significant. We are not asked to copy a liturgy but to emulate a spiritual pattern. This pattern was one of simplicity, of directness, of Spirit-filled preaching, of lay participation, of free prayer, of spontaneity. It was not mysterious, formal, ritualistic, priestly, or highly structured. It was the worship of simple, dedicated people who believed completely in Christ and who loved to express their adoration to $\mathrm{Him}^{2}$

The purpose of worship renewal is not to copy a specific style of worship, but to recapture the spirit of devotion to God.

Even though there are no liturgical patterns for worship by the early church which can be copied for later years, there are glimpses of elements that these first Christians brought into their worship which can be adapted for modern times. The purpose of this chapter is to examine how these elements were used in the early church and to see how they may be applicable for Christian worship today.

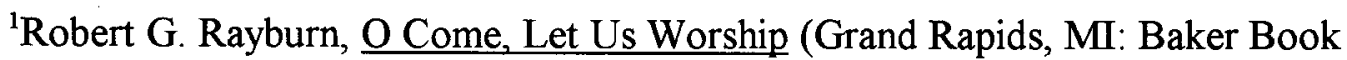
House, 1980), 77.

${ }^{2}$ Pease, 47, 48. 


\section{The Temple and the Synagogue}

The Christian church was first established in Jerusalem after the Day of Pentecost. These believers were greatly influenced by their Jewish heritage and environment and it was natural for their worship patterns to largely copy what they knew. As these first Christians assembled to worship, their services were continuations of the two basic Jewish institutions of worship--the temple and the synagogue. The temple services centered on the sacrificial ceremonies and the synagogue focused on the Word of God. George Ladd explains, "They continued the Jewish worship of God in the Temple."1 And Rayburn adds,

The first Christians, who were Jews, did not inaugurate an entirely new kind of worship. Jesus and His disciples worshiped in both the temple and the synagogue. After the ascension of Jesus, the Christian community continued many of the observances of both. ${ }^{2}$

These early Christians did not intend to establish radically new patterns of worship beyond what the Jews already practiced. Horton Davies comments, "The first company of Christians who met together in Jerusalem were Jews. This is an all-important fact, because it explains why the Christian church did not inaugurate an entirely new type of worship."3 As Webber further points out,

At first there was no hint that a new people of God, one including the Gentiles, was being formed as a result of these events. Therefore, early Christians

${ }^{1}$ George Elden Ladd, A Theology of the New Testament (Grand Rapids, MI:

William B. Eerdmans Pub. Co., 1974), 348.

${ }^{2}$ Rayburn, 78 .

${ }^{3}$ Horton Davies, Christian Worship: Its History and Meaning (New York: Abingdon Press, 1957), 19. 
worshiped in the synagogue until the growing conflict over the messiahship of Jesus forced them to go elsewhere. ${ }^{1}$

The first Christian worshipers simply built their worship services upon patterns which were familiar to them.

\section{The Temple}

The early Christians showed great reverence for the temple and its services and made it an integral part of their lives. The biblical record shows that at the beginning of early Christian history the believers centered much of their activity around the sacred building. The believers met daily in the temple courts. ${ }^{2}$ Peter and John went to the temple at the time of prayer. ${ }^{3}$ After the apostles were miraculously released from prison they went boldly and preached in the temple. ${ }^{4}$ And, years later, Paul went to the temple for an act of ritual purification. ${ }^{5}$

However, the temple did not for long continue to play a major part in the worship practices of the New Testament Christians. There were three major factors that diminished its importance for the believers.

First, even though for a time they attended different services at the sacred building after the ascension of Jesus, these Christians were aware that His death fulfilled the

${ }^{1}$ Webber, 41.

${ }^{2}$ Acts 2:46.

${ }^{3}$ Acts 3:1

${ }^{4}$ Acts 5:21.

${ }^{5}$ Acts 20:26. 
sacrificial system that the temple was founded upon. ${ }^{1}$ Since the true Lamb of God had already been sacrificed, all services that were performed in the temple had met their completion in the ministry, death, and resurrection of the Savior. These rituals had no further meaning to the Christian church.

Second, when Stephen was stoned by the Jews, severe persecution began against the Christians that drove them from Jerusalem. As a result they had no immediate access to the temple. ${ }^{2}$ Christianity became a world-wide movement ${ }^{3}$ that was no longer centralized in Jerusalem. Especially since there were now Christians from non-Jewish backgrounds, they needed to have a pattern of worship to follow that was different from the services of the temple.

The third reason the temple's importance diminished was that it ceased to exist. During the siege by the Romans in A. D. 70 the entire city of Jerusalem, including the temple, was destroyed. Because of these factors early Christian worship practices paralleled more closely the services of the synagogue rather than the temple.

\section{The Origin of the Synagogue}

At best, the beginnings of the synagogues are a mystery that cannot completely be explained. As Sonne says, "The beginnings of the synagogue cannot be certainly

${ }^{1}$ Acts 2:14-36.

${ }^{2}$ Acts 8:1.

${ }^{3} \mathrm{Col} 1: 6$ 
recovered; rabbinic sources offer no clue whatsoever." ${ }^{1}$ The most common explanation about the beginnings of the synagogue system is that it arose from necessity as the result of the Babylonian captivity of the Jews. Webber sums up the origin and purpose of the synagogue by saying,

The synagogue, (literally "gathering place" or "place of assembly") originated as a result of the destruction of Jerusalem and the temple and the subsequent dispersion of the Jewish people during the exile. A motivating concern was the preservation and propagation of the Word of the Lord in the context of the Jewish community. Thus the synagogue became the religious, educational, and social center of Jewish life. Through it the traditions of ancient Israelite religion were preserved and passed down from generation to generation. ${ }^{2}$

And James F. White comments, "The synagogue apparently originated as a survival agency."3

There were significant differences between the services of the temple and of the synagogue. As James Robertson says, "If temple worship emphasized God's sovereignty, the synagogue service stressed devotion to the Law." ${ }^{4}$ In an unpublished paper entitled "Congregational Worship in the New Testament and Early Church," Robert Johnston illustrates these distinctions:

The worship of the Temple consisted mainly of the sacrifices of animals and other consumables, which were offered on behalf of the nation and individuals by the priests. The priests were such by the virtue of heredity. They must be of the

${ }^{1}$ I. Sonne, "Synagogue," Interpreter's Dictionary of the Bible, ed. George Arthur Buttrick, (Nashville: Abingdon Press, 1962), 478.

${ }^{2}$ Webber, 36, 37.

${ }^{3}$ James F. White, Introduction to Christian Worship, 142.

${ }^{4}$ James D. Robertson, Minister's Worship Handbook Grand Rapids, MI: Baker Book House, 1974), 24. 
tribe of Levi and of the lineage of Aaron. There was only one legitimate Temple, according to Deuteronomy 12

By contrast, Synagogues were established wherever there were at least ten adult male Jews, forming a quorum (minyan). Synagogue worship, in obedience to Deuteronomy 12, involved no offering of sacrifices. Instead it centered on the reading and exposition of scripture, along with prayers. The elders and scribes of the law who ruled the Synagogues and were in charge of its worship could be of any of the tribes. Finally, the service of the Synagogue was essentially a meeting, an assembly for corporate worship every Sabbath, as well as on Mondays and Thursdays. ${ }^{1}$

What did the services at the synagogue include? According to Webber there were three major sections of worship: "Synagogue worship consisted of an affirmation of faith [the "Shema" which is found in Deut 6:4-9], prayer, and the reading of the Scriptures." The basis of synagogue worship was to focus upon prayer and upon instruction from the Word of God.

It is obvious that the synagogue's influence has been extended to the practices of worship in the Christian church. Davies explains the effect of the synagogue upon Christian worship:

The importance of the synagogue for our purpose is that its worship exerted a profound influence on the worship of the apostolic Church. The main elements of its worship were carried over into Christian services. The prayers, the praise, the reading of the Scriptures, and the exposition of them, were the fundamentals of Christian worship. Moreover, the worship of the synagogue was nonsacrificial in character, and it provided a place for a simple liturgy with responses, as well as extemporary prayers. Both these features were characteristic of apostolic worship. ${ }^{3}$

${ }^{1}$ Robert M. Johnston, "Congregational Worship in the New Testament and the Early Church," Andrews University, Berrien Springs, MI, n.d., 2.

${ }^{2}$ Webber, 37.

${ }^{3}$ Davies, 20. 
And William Maxwell also comments about the synagogue's influence on the Christians by saying, "From the beginning the reading and exposition of the Holy Scriptures in a setting of praise and prayer has been one of the essential elements in Christian worship. This is a direct inheritance from the Jewish synagogue."1

Although it exerted a profound influence on the Christians, the early believers did not consider their worship a direct copy of the synagogue service. Maxwell distinguishes the major differences between the Jewish synagogue worship and the practices of the Christian church:

But Christian worship was not a precise copy of the Synagogue worship. There was a new emphasis and content to accord with the new revelation and to express the new spirit. The Prophetic Books rather than the Law became the chief centre of interest. Soon, too, although more than a century passed before the canon was fixed, the Christian Scriptures began to take form, comprising letters and memoirs of the Apostles and others, collection of the sayings and acts of our Lord, and finally the Apocalypse. ... The Christians continued to use the Psalms in their worship much as they had been used in the synagogues, but also composed hymns of their own. Their prayers, too, though related in form to those of the Synagogue so that it was possible for all to take part, soon underwent a separate development, until a new body of devotion appeared, fitted to express the worship of those who had come to know God as revealed in Jesus Christ. ${ }^{2}$

Christian worship, therefore, was largely an adaptation of the familiar patterns of the Jewish synagogue worship. Although other modifications in worship patterns have been developed and refined (the earlier church further "Christianized" its worship practices by adding the ordinances of baptism and the Lord's Supper), the basic emphasis upon prayer and the Word of God remains to the modern era.

${ }^{1}$ William D. Maxwell, An Outline of Christian Worship: Its Development and Forms (London: Oxford University Press, 1936), 3.

${ }^{2}$ Ibid., 3, 4. 


\section{New Testament Scriptural Passages of Worship}

As was stated earlier, it is difficult to study early Christian worship from the New Testament because there is no definite liturgical pattern discernable in the Scriptures.

However, there are trends listed in several passages of the New Testament which show different elements of worship which were used.

Jesus, of course, is the supreme example for Christians to follow in all areas of life. In His patterns of worship the Bible records that Jesus prayed ${ }^{1}$ (including the model prayer that He taught His disciples), ${ }^{2}$ sang a hymn together with His disciples the night before His crucifixion, ${ }^{3}$ and read from the Scriptures when He visited in the synagogues. ${ }^{4}$ The Bible records that the early Christians also prayed, ${ }^{5}$ sang songs of praise, ${ }^{6}$ and read the Scriptures. ${ }^{7}$ The believers continued to follow the example set by Jesus, and still continue to follow His example to this day. As time went by the patterns of worship that were established by these believers became the norm that is followed by the Christian community in the modern era.

${ }^{1}$ Luke 6:12.

${ }^{2}$ Matt 6:9-13.

${ }^{3}$ Matt 26:30; Mark 14:26.

${ }^{4}$ Luke 4:16-21.

${ }^{5}$ Acts $4: 31$.

${ }^{6}$ Acts 16:25.

${ }^{7}$ Acts $17: 11$. 
Acts 2:42-47

One of the most enlightening New Testament passages about the spiritual and social activities of the early believers is found in Acts 2:42-47. This section of the biblical record of the early Christians does not illustrate a liturgical pattern of worship. It does, however, demonstrate the spirit in which the New Testament disciples approached their worship. To these Christians worship was not a once-a-week activity--it was an integral principle of life.

Four elements of Christian life which are illustrated in Acts 2:42--the focus on the teaching of the apostles, the fellowship, the breaking of bread, and prayer. Each of these deserves a short study as to how they affected the lives of the early Christian church.

The "apostles' teaching" placed the emphasis upon the Word of God. As Rayburn says, "This passage refers to the doctrine of the apostles, and certainly that expression by itself would mean New Testament truth as well as apostolic instruction from the Old Testament Scriptures." This passage in Acts is also considered to be the fulfillment of the Gospel Commission given by Jesus to His disciples before His ascension where $\mathrm{He}$ commanded His followers to teach new believers to "obey everything I have commanded you" (Matt 28:20). Early Christian activity centered upon the Word of God.

The second item listed in Acts 2:42 is "fellowship." True fellowship is caring for the needs of others, whether those needs are spiritual, physical, or financial. Other verses in this section amplify this concept by saying, "All the believers were together and had everything in common. Selling their possessions and goods, they gave to anyone as he

'Rayburn, 89. 
had need" (Acts 2:44, 45). Another mark of these believers was that they demonstrated their devotion to God by their love for each other.

Third on the Acts 2:42 list of activities is "the breaking of bread." Commentators are divided on the meaning of this phrase. Some consider it to be a reference to the Lord's Supper. F. F. Bruce provides a good example of this interpretation: "The 'breaking of bread' here denoted something more than the ordinary partaking of food together: the regular observance of the Lord's Supper is no doubt indicated." Others claim it to be no more than a common meal: "'breaking of bread" is a common New Testament phrase meaning 'to eat."'2

However it is interpreted, the process of eating together is one of the highest social activities human beings can share. In biblical times the act of eating together showed a close association between individuals. One of the greatest criticisms that the Pharisees leveled against Jesus was that they disapproved of the types of people He associated with. Instead of the elite of Israel's society, tax collectors, prostitutes, and other "undesirables" were attracted to Him. In condemnation the Pharisees sneered, "This man welcomes sinners and eats with them" (Luke 15:2). The fact that Jesus broke bread with these types of people demonstrated how closely involved He was with them.

${ }^{1}$ F. F. Bruce, Commentary of the Book of Acts (Grand Rapids, MI: William B. Eerdmans Pub. Co., 1954), 79.

2"Acts," SDA Bible Commentary, ed. F. D. Nichol (Washington, DC: Review and Herald Pub. Assn., 1953-57), 5:148, 149. 
The early Christians focused on God's Word, on fellowship by caring for each other, and on unity through eating and sharing the Lord's Supper together. To these three activities a fourth is added by Scripture, that of prayer.

Prayer is the essence of the spiritual life. Ellen G. White comments, "Unceasing prayer is the unbroken union of the soul with God, so that life from God flows into our life; and from our life, purity and holiness flow back to God."1 Prayer is the two-way channel of communication between the Creator and His creatures. It is how humanity and God speak together. Even the Savior spent many hours in personal communication with His Father through prayer. ${ }^{2}$

In the book of Acts, Luke shows that prayer was an important and integral part of the New Testament Church. Important decisions were made only after heaven's approval was sought. One was chosen to replace Judas only after prayer for guidance. ${ }^{3}$ The believers prepared to receive the Holy Ghost after praying together. ${ }^{4}$ When Peter and John were imprisoned, prayers of thanksgiving were offered after their release. ${ }^{5}$ And 1956), 98.

${ }^{1}$ Ellen G. White, Steps to Christ (Mountain View, CA: Pacific Press Pub. Assn.,

${ }^{2}$ Luke 6:12.

${ }^{3}$ Acts 1:24.

${ }^{4}$ Acts $1,2$.

${ }^{5}$ Acts 4:23-31. 
when Herod arrested and jailed Peter, again God answered the believers' prayers by miraculously setting the apostle free. ${ }^{1}$

With the aforementioned focus upon God's Word and prayer, the synagogue's influence was very pronounced upon the early Christians. They continued to worship and act in patterns which were familiar to them. And as a result of their activity a remarkable change took place in the church--it grew. Acts 2 closes with the observation that the Lord "added to their number daily those who were being saved" (Acts 2:47).

True worship is evangelistic. A worshiping congregation that centers upon God's Word, demonstrates its care for others, takes time to feed the spiritual and physical bodies, and lifts others up in prayer will have many who are wanting to join the Christian community because they have seen Christ's love demonstrated in a mighty way.

\section{Cor 14}

When looking at Paul's first letter to the Corinthian Church it becomes quickly obvious that the theme of the letter is to deal with problems that had arisen within the congregation. Unity, harmony, and love were not expressed between members of the congregation. Well-known topics that Paul addressed within the church body included divisions in the church, ${ }^{2}$ lawsuits between church members, ${ }^{3}$ immorality, ${ }^{4}$ the propriety of

${ }^{1}$ Acts $12: 12$

${ }^{2} 1$ Cor 3 .

${ }^{3} 1$ Cor 4 .

${ }^{4} 1$ Cor 5 . 
eating meat that has been sacrificed to pagan gods, ${ }^{1}$ the role of women in worship, ${ }^{2}$ and the usage of spiritual gifts, especially the gift of tongues. ${ }^{3}$ Almost lost in the discussion about problems are issues concerning worship. Yet, worship topics are one of the most important thrusts of this epistle.

The two major issues about worship in this letter center upon the misuse of the Lord's Supper service ${ }^{4}$ and the major bedlam, confusion, and chaos that characterized their divine worship services. ${ }^{5}$ The prevailing attitude seemed to be one of selfishness. If Christians are to be characterized by their love and generosity towards each other, these people still had much to learn in their spiritual journeys.

For example, the purpose of the communion service was to reflect upon the instructions given by Christ that all was to be done in remembrance of Him. ${ }^{6}$ The ceremony was specifically to remember the sacrifice of Christ and to point towards the time when all believers will unite in heaven and share in the supper together. ${ }^{7}$ Yet, certain members had taken this service and its accompanying meal as a personal opportunity to overindulge their appetites and leave as little as possible for others. Some, it seems,

\footnotetext{
${ }^{1} 1$ Cor 8.

${ }^{2} 1$ Cor 11 .

${ }^{3} 1$ Cor $12-14$.

${ }^{4} 1$ Cor 11 .

${ }^{5} 1$ Cor $12-14$

${ }^{6} 1$ Cor $11: 24,25$.

${ }^{7}$ Matt 26:29.
} 
started eating as quickly as possible and literally ate themselves into a stupor bordering upon drunkenness. ${ }^{1}$ Through selfishness the meaning of the ceremony had been almost completely lost.

The same self-centeredness was also demonstrated in the area of spiritual gifts. For some reason members had sided along lines as to which of the gifts had the most importance and prestige. Those who had the gift of tongues seemed to flaunt it while others thought the gift of prophecy should take precedence. ${ }^{2}$ The result to the congregation was chaos.

The key to Paul's thought about worship is found in his statement, "What then shall we say, brothers? When you come together, everyone has a hymn, or a word of instruction, a revelation, a tongue, or an interpretation" (1 Cor 14:26). In these words Paul gives us insights into two principles concerning worship.

First, he lists some of the common elements included in worship at that time, including instruction and music. While it cannot be stated that this list is a comprehensive liturgical order for worship, it does illustrate some elements that were integral to the early believers at Corinth. In giving this list Paul uses the same tactic as did Jesus when He was - asked by the disciples how to pray. The prayer we now call the "Lord's Prayer"3 was not meant to be the definitive prayer for the disciples, but a guideline as to the way each believer can approach God in a personal way.

${ }^{1} 1$ Cor 11:22.

${ }^{2} 1$ Cor $14: 39$.

${ }^{3}$ Matt 6:11-13. 
The second principle Paul gives us about worship is that all things must be done in an orderly fashion. Worship is to be characterized by dignity and balance, not chaos and confusion. As he says concluding his remarks on this subject of worship, "But everything must be done in a fitting and orderly way" (1 Cor 14:40). As Segler says,

Neither Jesus nor Paul proposed a particular order for public worship. However, both of them implied that there is a logical order for public worship. The model prayer includes a logical sequence of attitudes in worship, and Paul insists upon orderliness and thoughtful discipline in the worship service (1 Cor. $14: 40)^{1}$

The New Testament does not give us an example of liturgy that we can follow. Perhaps Pease states best our task in studying worship in the early Christian era when he says, "We are not asked to copy a liturgy but to emulate a spiritual pattern." That pattern is demonstrated in Christian worship as believers display order and discipline in all that they do. And that pattern is best illustrated as Christians demonstrate their love for God in ways that show love for their fellow believers. This pattern is one that the modern church can copy, demonstrating that Christians can indeed still make a difference to the world that surrounds them.

\section{$\operatorname{Rev} 4$ and 5}

Although Christians live presently in this world, it must never be forgotten that the true home of the redeemed is in heaven--"We are looking forward to a new heaven and a

\footnotetext{
${ }^{1}$ Segler, 27.

${ }^{2}$ Pease, 47.
} 
new earth, the home of righteousness" (2 Pet 3:13). Therefore, it would seem that patterns of worship upon earth should be typical of the worship patterns in heaven.

In his apocalyptic visions received on the Isle of Patmos, the Apostle John views an event encircling the throne of God in heaven. In this scene recorded in Rev 4 the central throne is surrounded by twenty-four other thrones upon which are seated twentyfour elders. Whenever God's glory is demonstrated, these elders prostrate themselves and lay their crowns before the throne. They worship God and sing praises to Him as the Creator of all. ${ }^{1}$

In the next few verses a new dimension is added--that of a lamb. This lamb is alive in spite of what seems to be a mortal wound. ${ }^{2}$ In an obvious reference to the sacrifice of Jesus Christ, the "Lamb of God, who takes away the sin of the world" (John 1:29), praise is now directed to God through the Lamb as Redeemer. This song of praise is started by the twenty-four elders who are closest to the throne and to the Lamb. They are joined by an innumerable company of angels who also encircle the throne. And finally they are joined by the entire creation who gives equal praise to the One on the throne and to the Lamb. $^{3}$

This heavenly scene truly illustrates the dynamics of worship. All worship begins with an awareness of the glory of God, a picture of His true holiness. His created beings

\footnotetext{
${ }^{1} \operatorname{Rev} 4: 10,11$.

${ }^{2} \operatorname{Rev} 5: 6$.

${ }^{3} \operatorname{Rev}$ 5:9-14.
} 
are reminded of His mighty power, the omnipotent God who is the Creator of the universe. That God is truly worthy of worship.

However, to view and worship Him only as Creator gives an incomplete picture of God. Through Jesus Christ humanity has a Savior God. Because of His power and His sacrifice, sinful humans become redeemed individuals whose sins are cleansed through the saving blood of the Lamb. ${ }^{1}$

The beauty of Christian worship is that Christians have as complete a picture of God as He has currently revealed to them. They worship Him as their Creator and Redeemer. And, as the Book of Revelation pictures, that worship which has begun upon this earth will continue as the redeemed worship together in heaven. A God who is Creator and Redeemer is a God doubly worthy of worship. This is the picture and focus of New Testament worship.

${ }^{1} \operatorname{Rev} 7: 14$. 


\section{CHAPTER 3}

\section{A THEOLOGY OF CHRISTIAN WORSHIP}

\section{The Need for Theology, Not Methodology}

During periods of liturgical revival much emphasis is usually placed upon reevaluating and modifying the methodology of worship. The reason for this is that most people within the Christian community equate worship reform as being synonymous with changes in the forms of worship. These changes can include modern music played upon modern musical instruments, updated language, drama, and, in some denominations, liturgical art and dance.

Worship must speak in the language of the people--in words, symbols, and music that people can comprehend. The goal of Bible translators (even the King James when it was translated as a "modern" version) has always been to communicate the Word of God in words and phrases the readers could understand. All that is done in worship must be geared to communicate the great truths of Christianity to a current audience. However, in their attempt to make worship services more attractive to contemporary humanity, churches too often have taken their patterns from modern society instead of biblical principles. 
This type of thinking is all too common as we approach the twenty-first century. The prevailing concept is that today's individuals from the non-Christian community must be comfortable when they visit a church. Therefore, the language and music must sound familiar to them and put them at ease. What is done in church becomes a parallel to modern society.

David Randolph gives us a good example of this pattern of modernizing worship services. In his book God's Party he says we not only need to learn to communicate in contemporary language, but we must also base our patterns of communication on the nonchurched people who are considered to be heroes among those in today's society. Randolph states: "We clearly need to be radically more experimental in our use of language. We need to learn from those who have the ears of the land: the sports writers, the comedians, the pop song writers--especially poets like Bob Dylan."

Randolph's philosophy (written in the mid-1970s) is clear--to make worship attractive it must make use of modern forms. And to him it is especially helpful to draw on celebrity influence to reach our society. Therefore, the form of worship under this theory becomes more important than the content of the worship service.

The same concept is prevalent in the 1990s. Rick Warren describes what is termed "seeker-sensitive services" as the best way to reach out to the unchurched:

What is the most natural way to increase the number of visitors to your church? .. The answer is quite simple: Create a service that is intentionally designed for your members to bring their friends to. And make the service so

${ }^{1}$ David James Randolph, God's Party (Nashville: Abingdon Press, 1975), 90. 
attractive, appealing, and relevant to the unchurched that your members are eager to share it with the lost people they care about. ${ }^{1}$

Warren's philosophy is to give people in worship services that which they are accustomed to and comfortable with in everyday life: guitars and drums instead of organs, praise songs styled after the adult contemporary popular music instead of hymns, etc. ${ }^{2}$ Again, methodology becomes the emphasis for worship renewal.

Marva Dawn disputes this trend in her recent work on the theology of worship. She comments why this philosophy is common by saying, "Debates about worship style usually arise because, in their desire to reach out to the culture surrounding us, parishes are striving to make worship meaningful to that society."3 Then Dawn shows why she opposes this type of worship philosophy. She continues,

It is my claim that we ought not to, and do not need to, conform to our culture's patterns, but that the Christian community must intentionally sustain its unique character and just as intentionally care about the culture around it in order to be able to introduce people genuinely to Christ and to nurture individuals to live faithfully. ${ }^{4}$

Granted, there must be different approaches in worship because of differences in cultures and audiences. A service geared toward evangelism might possibly be more "seeker-sensitive" in its approach in attracting non-Christians. But all worship must be governed primarily by theology instead of methodology.

${ }^{1}$ Rick Warren, The Purpose Driven Church (Grand Rapids, MI: Zondervan Pub. House, 1995), 253.

${ }^{2}$ Ibid., 279-292.

${ }^{3}$ Dawn, 93, 94.

${ }^{4}$ Ibid., 11 . 


\section{The Theology of Worship Renewal}

Genuine worship renewal is much more than merely changes in the worship format. True worshipers emphasize a change in the pattern of living. Worship reform must go deeper than a change in art or musical styles--true worship emphasizes a change in the heart. And this change does not begin with an increased knowledge of music or language--the focus must be upon God Himself.

Franklin Segler makes a pointed statement: "As we believe, so we worship." Whatever we believe about God will be demonstrated in the manner we worship Him--our "theology of worship."

As Marianne Micks says, "The word 'theology' comes from two Greek words-theos ('God') and logos ('word' or 'thought'). Theology is simply words about God or thinking about God."2

In essence, theology is the "science of God" ${ }^{3}$ and how He relates to His created universe. Humanity's theology of God states how, as created beings, individuals conceptualize the Creator and Redeemer God. Theology is these concepts put into word and action.

Theology must be more than mere cognitive knowledge; thoughts and beliefs about God will be actively demonstrated in how He is worshiped. Segler continues:

${ }^{1}$ Segler, 47.

${ }^{2}$ Marianne Micks, The Joy of Worship (Philadelphia: Westminster Press, 1982), 7.

${ }^{3}$ Augustus Hopkins Strong, Systematic Theology, 3 vols. (Old Tappen, NJ: Fleming H. Revell Co., 1907), 1:1. 
As we believe, so we worship. The doctrines we hold determine the nature of our worship. . . Worship without theology is sentimental and weak; theology without worship is cold and dead. Worship and theology together combine to motivate a strong Christian faith and to empower a fruitful Christian life. Worship should be regulated and determined by doctrine. ${ }^{1}$

The SDA Bible Dictionary gives biblical meanings of the word "worship," indicating that worship is "the attitude of humility, reverence, honor, devotion, and adoration that properly mark the relationship of created beings to their Creator, especially in His presence. The Bible teaches that such worship is due to the one true God alone."

Both Hebrew and Greek words for worship reflect this attitude of humility and reverence. The Hebrew word is generally a form of shachah, and the Greek is predominantly proskuneo, and both are defined as "to bow down" or "to prostrate oneself." An example of this comes from the book of Revelation where the twenty-four elders "fell down and worshiped" 4 the One on the throne and the Lamb. The true attitude of worship is one of awe, adoration, and humility before the Creator. This attitude is best expressed when created ones bow in homage before their Maker. This attitude of praise, honor, thanksgiving, and humility we call "worship."

The English word translated as "worship" has an interesting history. Ralph Martin states:

${ }^{1}$ Segler, 47

${ }^{2}$ SDA Bible Dictionary (1960), s.v. "Worship."

${ }^{3}$ Ibid.

${ }^{4} \operatorname{Rev} 5: 14$. 
Worship is a noble word. The term comes into our modern speech from the Anglo-Saxon weorthscipe. This later developed into worthship, and then into worship. It means "to attribute worth" to an object. . . In the Marriage Service of the Book of Common Prayer, the prospective husband's promise is "With my body I thee worship"--a pledge of utter loyalty and devotion to his bride, who is worthy of this, in his eyes. If we may elevate this thought to the realm of divine-human relationships, we have a working definition of the term worship ready-made for us. To worship God is to ascribe to Him supreme worth, for He alone is worthy. ${ }^{1}$

A theology of worship never begins with humanity, but with God. All true worship is based upon how God has demonstrated His love for His created beings throughout the history of this world. As Segler points out,

Christian worship is first an experience, not an art. It is based upon a historical fact, the fact that God revealed himself in history. Evangelical worship is grounded in the great historical facts of God's creation, the Incarnation, the works of Jesus Christ, his atoning death, his Resurrection, and his abiding presence in the life of believers. The way we think about these historic facts is called theology. Worship that is not grounded in the knowledge and love of God is not true worship. Theology that does not lead to the worship of God in Christ is both false and harmful. A sound theology serves as corrective to worship, and true worship serves as the dynamic of theology. ${ }^{2}$

\section{$\underline{\text { Revelation and Response }}$}

A Christian theology of worship must center around God, who alone is worthy of worship. In liturgical language worship is often illustrated as a combination of "revelation" and "response." God first reveals to humanity a portion of His character, His greatness, or His love. As Millard Erickson says, "Because man is limited and God . . . is

\footnotetext{
${ }^{1}$ Ralph P. Martin, Worship in the Early Church (Grand Rapids, MI: William B. Eerdmans Pub. Co., 1964), 10.

${ }^{2}$ Segler, 47,48 .
} 
superior to him in many ways, God must take the initiative in establishing the relationship."1 God is an active God, constantly reaching out to His created ones.

There are two major modes in which God has revealed His character and personality to humanity throughout history: as our Creator and as our Redeemer.

Through these activities God has revealed Himself openly and completely to all of the universe.

The first Scriptural record of His revelation comes during the Creation week. The most powerful word in the Scriptures is the word "create." The opening sentence in the Bible declares, "In the beginning God created the heavens and the earth" (Gen 1:1 KJV). Here we see God revealed as the mighty Creator. Only the God of heaven has the ability to create something from nothing.

As the Seventh-day Adventist Bible Commentary states, "The verb 'to create' is derived from the [Hebrew] 'bara', which in the form here used describes an activity of God, never of men."2 Only the Creator God has the ability to bring worlds into existence through the power of His spoken word. ${ }^{3}$

God's crowning act of creation was Adam and Eve. He revealed Himself as a god who craved the companionship of His created beings, and He gave them the Sabbath as a sign of that relationship. Humanity's response to God's creative power was to spend the

${ }^{1}$ Millard J. Erickson, ed., The Living God: Readings in Christian Theology (Grand Rapids, MI: Baker Book House, 1973), 115, 116.

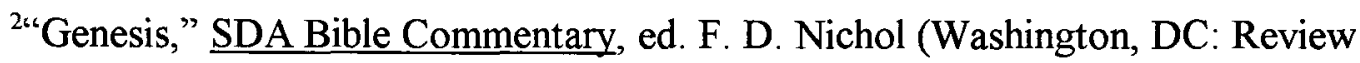
and Herald Pub. Assn., 1953-57), 1:208.

${ }^{3}$ Ps 33:6, 9. 
first full day of life, the Sabbath, in communion with the Creator. Adam and Eve walked and talked openly with their Maker. Their loving response to Him as Creator was worship.

But Adam and Eve's Creator/creature relationship would be spoiled, and their worship of God would take on an added dimension. They would experience God's selfrevelation as Redeemer.

When sin invaded this universe, prior to the creation of this world, a great cosmic battle began. The basis of this struggle (which SDAs refer to as the "Great Controversy") is worship. Satan has claimed the homage which God declares is His alone. The issue in this battle is the question, Is God worthy of worship or is Satan a better choice?

Satan demonstrated his desire for worship during his third temptation of Christ. He claimed Jesus did not have to die in order to reclaim this lost world, but that it would be His if only He would "bow down and worship me [Satan]" (Matt 4:9). Satan craved the worship due God alone and rejoiced that he had the inhabitants of this world under his domain.

The very day Adam and Eve sinned was when God revealed Himself in His second way. The Creator God became the Savior God, the re-Creator. Sin had corrupted the sinless heart and nature of humanity, and human attention was now self-centered instead of God-centered. It was necessary to bring humanity back into harmony with divinity through a revelation of God's redemptive power.

David testified to this power after his sin with Bathsheba when he prayed, "Create in me a pure heart, O God" (Ps 51:10). In this verse the Hebrew word for "create" is 
again bara and, as only God has the power to create, He alone has the power to re-create and renew the sinful heart. "God does not merely cleanse the heart; He creates in His forgiven child a new heart." Paul states: "Therefore, if anyone is in Christ, he is a new creation; the old has gone, the new has come!" (2 Cor 5:17). Redeemed people are not merely modified sinners--they are completely new creatures.

At the gate of Eden God revealed Himself as Savior as He related to Adam and Eve the Plan of Salvation and promised them a Redeemer. Addressing the serpent $\mathrm{He}$ said, "I will put enmity between you and the woman, and between your offspring and hers; he will crush your head, and you will strike his heel" Gen 3:15). A synonym for "enmity" is "hatred," or, as the dictionary states, "Positive, active, and typically mutual hatred or ill will."2 We, as sinners, cannot hate sin. James tells us that our sins come from our own evil desires. ${ }^{3}$ However, God, with His re-creative power, steps in and enables us to love righteousness and hate iniquity.

Sin's first effect on humanity interrupted intimacy with God. Previously, it had been Adam and Eve's delight to walk and talk face to face with their Creator. But now, before the Holiest of heaven, the pair felt inadequate and naked. They ran and hid from the One who was not only their Creator, but also their best friend.

1"Psalms," SDA Bible Commentary, ed. F. D. Nichol (Washington, DC: Review and Herald Pub. Assn., 1953-57), 3:756.

${ }^{2}$ Webster's Ninth New Collegiate Dictionary (1984), s.v. "enmity."

${ }^{3}$ Jas 1:13. 
However, God would now reveal Himself to fallen humanity in a new and special way. As He covered their nakedness with the skins of animals, Adam and Eve were directed to the covering of their sins by the robe of Christ's righteousness. The ultimate revelation from heaven was that the Creator would become Redeemer for sinful humanity.

When God reveals Himself, humanity's response is to worship. As Segler says, "Worship is the loving response of the creature to his Creator." James Christensen agrees as he says, "God is worshiped for His own glory. Worship is man's loving response to God's personal revelation in Jesus Christ. Genuine worship takes place only when God is worshiped for His own sake." Segler further expands his comments by saying,

Worship depends upon revelation, and Christian worship depends upon the revelation of God in Christ Jesus. Worship is therefore a revelation and a response which springs from the divine initiative in redemption. By faith we respond to grace as we find it in a face-to-face encounter with God. ${ }^{3}$

And John Stott summarizes this concept of "revelation and response" by saying, "All Christian worship, public and private, should be an intelligent response to God's selfrevelation."

One of the best descriptions of this type of encounter is in the story of Enoch, the man who "walked with God" (Gen 5:22). As Segler describes the scene,

${ }^{1}$ Segler, 58.

${ }^{2}$ James L. Christensen, Don't Waste Your Time In Worship (Old Tappen, NJ: Fleming H. Revell Co., 1978), 30.

${ }^{3}$ Segler, 48 .

${ }^{4} \mathrm{John}$ R. W. Stott, Your Mind Matters (Downer's Grove, $\mathrm{IL}$ : InterVarsity Press, 1972), 32. 
Enoch lived in constant fellowship with God. "Enoch walked with God; and he was not, for God took him" (Gen. 5:24. The Hebrew word walked suggests an intimate fellowship between Enoch and God. The literal translation is they "walked back and forth together." Enoch not only worshiped God at stated times, but he lived in continuous relationship with his Creator. ${ }^{1}$

Enoch's relationship with his God became the example to all who had observed his testimony of worship.

The New Testament continues the emphasis on complete and total dedication to God. Jesus summarizes Moses's command on how to love God ${ }^{2}$ by saying we should love Him with all our heart, soul, strength, and mind. ${ }^{3}$ This means we are to glorify God in all that we do emotionally, spiritually, physically, and mentally. We are to love the Creator with every facet of our being, and respond in worship to Him in all that we do.

However, not everyone responds in love to the revelation God gives due to the influence of sin upon the entire nature of humanity. Because sin places self at the center of life instead of God, the sinful human heart wants to be independent from His wishes. In the example of Cain and Abel, ${ }^{4}$ we discover that humanity is given a choice to either follow God or to reject His appeals. By refusing to follow God's directions for a sacrifice to Him, Cain ultimately chose to follow his own sinful path. He became the father of all who willfully reject God.

${ }^{1}$ Segler, 15.

${ }^{2}$ Deut 6:4.

${ }^{3}$ Luke 10:27.

${ }^{4}$ Gen 4:1-16. 
As time passed the division between those who followed the example of Abel and remained true to God and those who followed the rebellion of Cain became more distinct.

Ellen G. White comments on this separation by saying,

The faithful had worshiped God before; but as men increased the distinction between the two classes became more marked. There was an open profession of loyalty to God on the part of one, as there was of contempt and disobedience on the part of the other. ${ }^{1}$

Gen 4:26 is a crucial text in the study of worship because it indicates the beginnings of a more formalized type of public assembly. There developed a marked distinction between the descendants of Cain, who went their own sinful way, and the descendants of Seth, who remained true to God. One who became a leader in the worship of God was Seth's son Enosh. The verse simply states, "Seth also had a son, and he named him Enosh. At that time men began to call upon the name of the Lord" (Gen $4: 26)$.

The SDA Bible Commentary describes this new development in the public worship of God:

In his time a more formal worship was begun. Man had of course called upon the Lord before Enos' [Enosh NIV)] birth, but as time went on a more pronounced distinction arose between those who worshipped the Lord and those who defied Him. The expression "to call upon the name of the Lord" is frequently used in the OT to indicate, as it does here, public worship (Psalms 79:6; 116:17; Jeremiah 10:25; Zephaniah 3:9). ${ }^{2}$

Another comment on this passage is from the Keil and Delitzsch Old Testament commentary:

${ }^{1}$ Ellen G. White, Patriarchs and Prophets, 80.

2"Genesis," SDA Bible Commentary, 1:244. 
We have here an account of the commencement of that worship of God which consists in prayer, praise, and thanksgiving, or in the acknowledgment and celebration of the mercy and help of Jehovah. When the family of the Cainites, by the erection of a city [Gen 4:17], and the invention and development of worldly arts and business, were laying the foundation for the kingdom of this world; the Sethites began, by united invocation of the name of the God of grace, to found and erect the kingdom of God. ${ }^{1}$

God continued this revelation through object lessons of His love during the course of human existence. By far the greatest self-revelation of God to sinful humanity in the Old Testament was the Exodus from Egypt. During an awesome display of His mighty power, God took a people who had been captives in slavery and delivered them. Not only did He rescue them from their oppressors, but He also drowned the army that was pursuing them. When they were thirsty He provided water, and when they were hungry He began the miracle of the manna, which would last until they entered into the Promised Land.

The people's response in worship is best shown as they were encamped before Mt. Sinai. As God thundered His presence and declared His law to them, the congregation prostrated itself before Him. 'Moses alone had gone up the mountain to receive God's commands, and as he relayed them to the Children of Israel, they responded with one voice, "Everything the LORD has said we will do" (Exod 24:3).

But it was not only to experience the redemption from Egypt that God designated the Children of Israel to be His chosen people. They were also entrusted with the mandate to prepare the world for the coming of the Messiah. The tabernacle services were to point

${ }^{1}$ K. F. Keil and F. Delitzsch, Biblical Commentary on the Old Testament, 10 vols. (Grand Rapids, MI: William B. Eerdmans Pub. Co., 1952), 1:120. 
to the lesson of greater deliverance from sin that would be accomplished not from the sacrifice of any earthly lamb, but through the death of the Lamb of God.

The Exodus from Egyptian bondage revealed God as a loving, compassionate, and powerful God. However, the epitome of His self-revelation was poured out at the Cross where the ultimate payment for sinful humanity, the life of God's Son, was given as a ransom to redeem the fallen ones from sin. Humanity was to respond in loving obedience and worship to the God who had provided a means of salvation from sin. Their lives must be a testament to the saving power of God.

This brings us to a second Greek word for worship, latreuo, and is "often translated 'service' or 'worship."' Paul commands the Roman Christians to "present your bodies as a living sacrifice ... which is your reasonable service" (Rom 12:1). The word "service" as translated in the King James comes from latreuo, and is rendered "worship" in the NIV. As Klaus Hess states:

The man who has been reconciled and renewed carries out his worship of God through the Spirit by presenting his whole being. Since the Spirit of God takes control of a man's spirit for service in the gospel (Rom. 1:9), it leads to the surrender of the whole life, which is spiritual worship (Rom.12:1; NEB "the worship offered by mind and heart). ${ }^{2}$

The ultimate worship of God is a life of devoted loving service for Him.

The record of the prophet Isaiah's encounter with God gives an insight into the nature of this service. When confronted with the grandeur, majesty, and holiness of God,

${ }^{1}$ James F. White, Introduction to Christian Worship, 33.

${ }^{2}$ Klaus Hess, "Latreuo," Dictionary of New Testament Theology, ed. Colin Brown (Grand Rapids, MI: Zondervan Pub. House, 1971), 3:549-551. 
the reaction of Isaiah was to bemoan his lost condition. Then, in his vision, his sin was taken away by the mercy and grace of God, and he heard the question asked, "Who will be my messenger?"' Isaiah's response, because he had experienced salvation, was to volunteer in loving service to whatever God wished for him to do. ${ }^{1}$

As Isaiah demonstrates, true worship is a recognition of God's revelation of holiness and the service that comes through the cleansing of our sins through the sacrifice of Christ and the grace of God. Possibly the reason that this type of worship is not prominently demonstrated in today's Christian society is that too many equate worship only with the intellectual assent of the existence of God. They want to recognize Him in the form of their liturgical patterns once each week, instead of the liturgy of their lives on a daily and continual basis. They have not truly had an experience of the cleansing power of God.

Jesus gives us an explanation of the results of the human encounter with the divine. In His discourse with the Samaritan woman, He states the basis of true worship by saying, "Yet a time is coming and has now come when the true worshipers will worship the Father in spirit and in truth, for they are the kind of worshipers the Father seeks. God is spirit, and his worshipers must worship in spirit and in truth" (John 4: 23, 24).

Ellen G. White has some very direct comments about Jesus' words of worshiping God in spirit and in truth when she says,

Not by seeking a holy mountain or a sacred temple are men brought into communion with heaven. Religion is not to be confined to external forms and ceremonies. The religion that comes from God is the only religion that will lead to

${ }^{1}$ Isa 6:1-8. 
God. In order to serve Him aright, we must be born of the divine Spirit. This will purify the heart and renew the mind giving us a new capacity for knowing and loving God. It will give us a willing obedience to all His requirements. This is true worship. It is the fruit of the working of the Holy Spirit. By the Spirit every sincere prayer is indited, and such prayer is acceptable to God. Wherever a soul reaches out after God, there the Spirit's working is manifest, and God will reveal Himself to that soul. For such worshipers He is seeking. He waits to receive them, and to make them His sons and daughters. ${ }^{1}$

\section{The Work of the Holy Spirit}

In the divine wisdom written in God's Word believers are counseled to "Trust in the LoRD with all your heart and lean not on your own understanding; in all your ways acknowledge him, and he will make your paths straight" (Prov 3:5, 6). As has been already stated, during the periods of "worship wars" which the church has fought over the centuries much of the debate has ignored a theology of worship and has centered upon methods as a means of liturgical renewal. That emphasis has often placed a premium on human understanding and wisdom, at times to the neglect of divine guidance.

However, there is one factor which must not be ignored in considering human response in worship, and that is the work of the Holy Spirit. He is the agency through which heaven impacts not only the lives of individual Christians, but also in the working of the united corporate body of Christ. Without the impulses of God's Spirit all human activity is ultimately futile.

The Holy Spirit is how God prompts us in our spiritual walk. We are reborn, not through human origin, but born from above through the Holy Spirit and given grace to

${ }^{1}$ Ellen G. White, The Desire of Ages (Mountain View, CA: Pacific Press Pub. Assn., 1898), 189. 
receive salvation. ${ }^{1}$ His mission is to lead fallen humanity to the Redeemer. ${ }^{2}$ He guides into all the truth heaven reveals about Jesus Christ. ${ }^{3}$ Jesus assured His disciples that even though He was leaving them and returning to heaven, when the Holy Spirit came to them it was as if He Himself were still in their midst. ${ }^{4}$

The Holy Spirit is also active in humanity's worship. If worship is defined as a human response to God's self-revelation, it is through Him that the great truths of the God who is worthy of worship can be understood. Through Him heaven brings to the church the reality of divine love. He prompts human response to God's demonstrations of grace. And Paul even tells that the Spirit intercedes in our prayers so that those offerings of worship become acceptable to God. ${ }^{5}$

In the process of redemption there is, however, one caution that must be made about the Holy Spirit--He is not our Savior. It is His mission to point to the Redeemer. ${ }^{6}$ Heaven's goal is that through His ministry the reality of the cross and the beauty of the sacrifice of Jesus Christ become so real that humans will choose to respond in loving obedience to the Savior. That response is best described as worship.

${ }^{1}$ John 3:5, 6 .

${ }^{2} 1$ Cor $12: 3$.

${ }^{3}$ John 16:13.

${ }^{4}$ John $14: 17,18$

${ }^{5}$ Romans 8:26.

${ }^{6}$ John 16:14. 
Summary of the Theology of Worship

In summation, a theology of worship has four major components. First, the worshiper must recognize God's revelation of Himself as the Creator. The Psalmist states, "The heavens declare the glory of God; the skies proclaim the work of his hands." (Ps 19:1) Those who worship God must realize that they are part of His creation, and give Him the glory due as their Creator.

Second, worshipers must recognize and acknowledge God's revelation of Himself as the Redeemer. Only through Jesus, God's Son, can salvation be received, "for there is no other name under heaven given to men by which we must be saved" (Acts 4:12).

However, there must be more than head-knowledge about Jesus as Savior, for "the devils also believe, and tremble" (Jas 2:29). True worship means that thoughts known become actions completed. Christians worship by every thought, impulse, and deed. The third point of worship is to demonstrate publicly the acceptance of Jesus as Savior and Lord of the life. This response to God comes as a divine prompting under the guidance of the Holy Spirit.

And, finally, those who worship the God who has revealed Himself as Creator and Redeemer will respond in obedient loving service for what He has done for them. They will follow the example of the Samaritan woman and not wait to share with others the Savior they have found and experienced. These are the ones who truly worship "in spirit and in truth," and they are the true worshipers for whom heaven is seeking. 


\section{CHAPTER 4}

\section{ELEMENTS IN WORSHIP}

Upon entrance into a typical Protestant church (SDA churches included), worshipers are normally greeted with handshakes and are given a bulletin. The primary purpose of this weekly publication is to list the order of service for the worship hour, dividing the service into different activities. This order of service becomes the guide for Christians to follow during the worship time.

As Christians assemble for worship, they are expected to participate. Corporate worship contains a number of elements where believers demonstrate their personal and united praise to their God.

To begin worship Christians gather together in a place. When assembled, believers participate in personal and united prayer. A receptacle of some type is passed in which to collect the offering. Music of combined voices express the praise of those assembled through the congregational singing of religious songs. Music that is heard by the believers, such as vocal and instrumental specials, also expresses praise. Congregations listen as the Word of God is read to them (or by them) in Scripture lessons. The Word of God is presented in the spoken word of the sermon. Depending upon the denomination, the sacrament of the Lord's Supper may be celebrated (some denominations celebrate this 
ordinance every week; SDAs normally observe the Lord's Supper four times each year). These elements combined together in an orderly way make up the majority of most Protestant worship services.

During the decades of the 1980s and 1990s the SDA Church has been faced with the challenge and controversy of worship reform, similar to what other denominations experienced earlier in the 1960s. During these periods of "worship wars"1 much of the discussion of reform centers upon the methodology of worship. It is typical that during these situations many opinions are expressed on every side of the issue. Robert Webber gives a good summation of the attitudes and opinions proclaimed in these types of controversies over worship styles:

First, there are the traditionalists who want worship to be as it was. These are the people who resist change or are so deeply committed to a particular historical model of worship that talk of incorporating new styles of worship is intolerable. Second, there are those who wish to jettison traditional worship as irrelevant and go in search of a worship that is contemporary. ${ }^{2}$

Webber continues by saying that neither one of these approaches the real issue of worship renewal. He supports a position which would combine the best of the old and the new: "A third approach ... blends both the old and the new, a worship that respects the tradition yet seeks to incorporate worship styles formed by the contemporary church."3 I personally support Webber's position. As SDAs and other denominations are faced with renewal of worship, there is a great tendency to abandon all that is considered

${ }^{1}$ Dawn, 3 .

${ }^{2}$ Webber, 12,13

${ }^{3}$ Ibid., 13. 
"old" as outdated and irrelevant. However, this attitude eliminates much of the beauty of the tremendous Christian heritage which is handed down from preceding generations. True worship renewal will attempt to capture the best from the past and blend with it the best from new traditions of worship.

The purpose of this chapter is not to give an in-depth discussion of all the various elements of the worship service--that task is far beyond the boundaries of this study. Rather, this chapter summarizes a historical study of five of these worship elements, the place of worship, music, prayer, the reading of the Scriptures, and the sermon, and examines how they have been used in the Christian Church. Finally, each of these elements is evaluated as used in a typical SDA worship service.

The goal of this chapter is to inform the reader of the history and purpose of these basic elements of worship. It is hoped that this study will stimulate thought and discussion on how congregations can best understand and express their devotion and praise to God in a corporate worship setting.

\section{The Place in Worship}

Worship is the act of a personal human response to a loving and self-revealing God. As such, worship is an integral part of the Christian's daily life which cannot be confined to specific times and places. As Robert Webber says, "Throughout the history of the Christian church, believers have worshiped in a variety of places. Fields, catacombs, riverbanks, homes, prisons, ships, and planes have provided the setting for worship."1

${ }^{1}$ Ibid., 137. 
But down through the centuries the Christian believers have localized most of their corporate worship practices to specific places which are dedicated to God for that distinct purpose. Webber continues by saying, "Yet, it has become normal for Christians to have a place of worship. Consequently, churches, cathedrals, and auditoriums have become particular houses of worship."1

Scripture records that God Himself gave instructions for the Children of Israel to establish a specific place for worship. After the exodus of the Children of Israel from Egypt, God established the tabernacle, where His people could as a united congregation express their worship. As Harold Hannum comments, "While God may be worshiped sincerely in the most primitive surroundings, He gave His approval to David and Solomon in their erection of the most beautiful temple they were able to build for the worship of God."2 Centuries later, when the Israelites were permanently settled in the Promised Land, the temple during the reign of Solomon became the permanent structure as their house of worship.

When the Christian Church was in its infancy, the early believers were at first clustered around Jerusalem. Since these members were of Jewish descent, their houses of worship continued to parallel those of the Jews. The first Christians continued to use the temple and the synagogue as their places of worship.

${ }^{1}$ Ibid. 26.

${ }^{2}$ Harold B. Hannum, Music and Worship (Nashville: Southern Pub. Assn., 1969), 
The beginnings of the shift from established Jewish customs by the Christian community began early in the history of the church. The stoning of Stephen at the hands of the Jews inaugurated a major time of persecution against the followers of Jesus. Jerusalem was no longer Christianity's center because believers were forced to scatter to other regions. ${ }^{1}$ And when the Gentile world was touched by the message of Jesus, the Jews became a minority in the Christian world. For the Christian church the temple had lost its significance.

Where did the earliest Christians congregate to worship their God? James F. White gives us an indication of their practices:

As to the architectural setting of worship in the New Testament, it seems largely confined to private homes such as the third floor apartment in Troas (Acts 20:9). In several instances, such as that of Philemon, it was a private home (1:2). This indicates relatively small assemblies, often meeting behind locked gates (Acts 12:12-16), breaking of bread at home (Acts 2:46). In Ephesus, Paul used a lecture hall for two years (Acts 19:9-10) although this does not necessarily indicate worship. The various references to baptisms suggest that some occurred in homes (Acts 10:47; 16:33), but on such occasions as Pentecost the three thousand must have been baptized in some outdoor pool. ${ }^{2}$

As years progressed and Christianity became more socially and politically correct, meeting places began to evolve into more specialized centers of worship. As was stated in chapter 2, the pattern of the Jewish synagogue exerted much influence on Christian worship. Many of the visible symbols used in the synagogue services found their way into Christian practices. According to Webber,

\section{${ }^{1}$ Acts $8: 1$.}

${ }^{2}$ James F. White, A Brief History of Christian Worship (Nashville: Abingdon Press), 38. 
The theological character of space [as used in the synagogue] can be noted in the location of the congregation and the furniture. The congregation gathered around those material symbols that signify the means through which God had made Himself known in history. ...

From this vantage point both the scribes and the congregation were able to see the symbols that communicated the meaning of their gathering. The central symbol was the ark, which was the holiest object of ancient Israel and the only object allowed in the Holy of Holies. The people viewed the ark as a throne where God (an invisible spirit) was present. Inside the ark, which was similar to a wooden casket, were the scrolls, the testimony to God's communication to Israel. The ark and the scrolls were protected by the veil, and in front of that burned the seven-branch candlestick. All these material objects pointed beyond themselves to the presence of God in the history of Israel and his continued presence with his people.

Another feature of the synagogue was the bema, the raised platform on which the lectern stood. It was from here that the Scriptures were proclaimed and prayers were offered. The bema symbolized the place of the Word of God in the midst of the people, and the people gathered around the Word to hear God speak and to speak to God. ${ }^{1}$

Christians eventually adapted these practices to their unique patterns of worship,

and the basics of these patterns are still evident to this day. Many churches still have raised areas in the sanctuary as the focal point of worship. The platform is the specific area which draws the attention of those who are assembled. The one who is to proclaim the Word of God is central and lifted up, as was the place of the bema in the synagogue. For many Protestants the proclaiming of God's Word continues to be the primary focus of the worship service.

As for buildings which were used for worship among the early Christians, James F.

White says,

${ }^{1}$ Webber, 140 . 
There were churches built, to be sure, before Constantine. His predecessor, Diocletian, had had one destroyed in Nicomedia because it overshadowed imperial buildings. And court cases and records of floods reveal the existence of others built when persecution was relaxed. But in general, it was safer for Christians to worship in private homes during much of the first three centuries. ${ }^{1}$

It was during the reign of Constantine that church architecture took a drastic and long-lasting turn. As Janson comments, "With the triumph of Christianity as the State religion under Constantine, an almost overnight blossoming of church architecture began." 2 This was when civil basilicas were made available to different congregations for worship. Janson continues by saying that because Christianity had become acceptable, "impressive new buildings were wanted, for all to see." The era of large and grand centers of worship had begun.

In the pagan world basilicas had been locations to deal with civil government and had also been courts of Roman law. James F. White likens them to county courthouses. ${ }^{4}$ But during the Constantine Era numerous basilicas were donated to the Christian church to be used as places of worship. ${ }^{5}$ Newly constructed churches were also designed on this basilica style. ${ }^{6}$

${ }^{1}$ James F. White, A Brief History of Christian Worship, 72.

${ }^{2} \mathrm{H}$. W. Janson and Joseph Kerman, A History of Art and Music (New York: Harry N. Abrams, Inc., n.d.), 41.

${ }^{3}$ Ibid.

${ }^{4} J a m e s$ F. White, Introduction to Christian Worship, 99.

${ }^{5}$ Webber, 141.

${ }^{6} \mathrm{Ibid}$ 
What was most significant in this development was how the architectural style transformed worship. In the synagogue model the worship leaders were directly in the midst of the worshipers. The congregation encircled the area where activity took place and worshiper observance and participation were relatively easy. The basilica style changed that. The focal point of worship was pushed to the end of the building. Where there had been many doors into the basilica, especially on the sides for easy access, now the entrances were concentrated on one end, normally the western entrance. ${ }^{1}$ The place where the judge had previously sat became the place where the clergy led worship. This was seen as a move of authority, and the bishop symbolically and factually gained a new measure of power. As Webber says,

The bishop gradually assumed more power as the people raised him to a status far beyond that of a servant of the church. Gradually the bishop became an authority outside of the collective body of the people, lost his link with the people, and became a lord over them. This movement took some time to be completed, but it slowly reshaped Christian worship. What was once the collective work of the people gradually became the privilege of the clergy, and the use of space symbolized that shift. ${ }^{2}$

These architectural changes also contributed to a major shift in the dynamic of Christian worship. The members of the congregations lost much participation in their worship services. By the era of the Middle Ages worship had became a spectator activity for the members of the congregation--the act of worship itself was largely done by the clergy.

\footnotetext{
${ }^{1}$ Janson and Kerman, 41.

${ }^{2}$ Webber, 141 .
} 
Even though the Protestant Reformation attempted to change the patterns of worship and return more participation to the people in the congregation, the basic church architecture remains largely unchanged to our modern era. There are still specific places for clergy and members to occupy during the church services. A "spectator sport" mentality still rules too many congregations in their corporate worship because the congregation watches the worship that is presided over and done by the clergy.

A major challenge facing SDAs and any other denomination interested in worship renewal is to increase participation in the worship services by the people of the congregation. One subtle way is through architecture. Many congregations now worship in facilities where the worshipers are not seated in rows from the base of the platform to the rear of the sanctuary. Their arrangement is more in a semicircular fashion, placing the pulpit centrally among the people. This helps to increase the sense of intimacy and closeness as people hear the word of God.

\section{Music and Worship}

Our definition of worship focuses upon humanity's response to God's selfrevelation. This response often takes artistic forms, especially that of music. A study of the Bible shows that music has always been a factor in worship. The Old Testament contains several songs of worship and praise. After the Israelites were delivered from the Egyptian army, Moses led the men in a song of praise for their deliverance. ${ }^{1}$ When their

${ }^{1}$ Exod 15:1-18. 
song was completed, Miriam, the sister of Moses and Aaron, led the women in praise, accompanied by tambourines and dancing. ${ }^{1}$

King David was a composer as well as a singer and instrumentalist. The Book of Psalms is rich with his compositions, and one of his songs even chronicles his unfortunate affair with Bathsheba. ${ }^{2}$

When the temple in Jerusalem was being prepared for worship, much care was given to the usage of music in its services. Four thousand of the Levites were designated to praise the Lord with musical instruments that were provided them. ${ }^{3}$ Some of these instruments mentioned in the Bible listed for the temple services include cymbals, lyres, and harps. ${ }^{4}$ Trumpets and "other instruments" are mentioned at the dedication of the temple. $^{5}$ Years later, when confronted by an enemy, King Jehoshaphat utilized music in a most unique manner when he placed a choir in front of his army to inspire his people in a time of war. ${ }^{6}$

Examples of musical praise are also recorded in the New Testament. James F. White says,

${ }^{1}$ Exod 15:19, 21.

${ }^{2}$ Ps 51.

${ }^{3} 1 \mathrm{Chr}$ 23:5.

${ }^{4} 1 \mathrm{Chr}$ 25:6.

${ }^{5} 2 \mathrm{Chr} 5: 12,13$.

${ }^{6} 2 \mathrm{Chr} 20: 21$. 
The first two chapters of Luke contain the hymns of Elizabeth (1:42-45), Mary (1:46-55), Zechariah (1:68-79) and Simeon (2:29-32). The angel chorus sang for the shepherds over the fields of Bethlehem the night Jesus was born. Paul told the believers to share "songs, hymns, and spiritual songs."

And the Book of Revelation gives instances where created beings break into songs of praise for God and Christ. ${ }^{2}$

James F. White claims that several familiar passages of the New Testament could have existed as hymns for the early Christians, citing as examples Phil 2:6-11, Rom 11:3335, Col 1:15-20, and Eph 5:14. He even claims the love chapter, 1 Cor 13, may have been a hymn of the first-century Christians. ${ }^{3}$ Music was a strong part of Biblical life.

A survey of the history of the Christian Church from the New Testament period until the modern era illustrates that music has continued to be a major part of worship. Ambrose (339-397), bishop of Milan, "wrote hymn texts and taught his congregation to sing them."4 Gregorian Chants (named after Pope Gregory the Great, 540-604) were sung by monks in the monasteries in the Middle Ages. The Reformation re-instated congregational hymn singing supported by Martin Luther and, later, the Wesley brothers.

${ }^{1}$ James F. White, A Brief History of Christian Worship, 37.

${ }^{2} \operatorname{Rev} 5: 9-14 ; 14: 2,3 ; 15: 2-5$.

${ }^{3}$ James F. White, A Brief History of Christian Worship, 37.

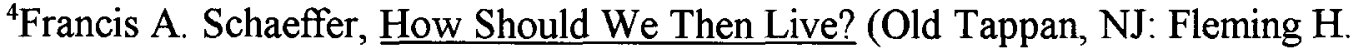
Revell Co., 1976), 90.

${ }^{5}$ Norman Lloyd, The Golden Encyclopedia of Music (New York: Golden Press, 1968), 215. 
Perhaps the "golden age" of religious music occurred during the Baroque era, specifically following the Protestant Reformation. Music of this period included the choral and instrumental music of the man whom some consider to be the most prolific and the greatest composer of all time, Johann Sebastian Bach. Many of his scores carried inscriptions indicating that the music was written for the express glory of God. ${ }^{1}$ This period also saw the composition of George Frideric Handel's oratorios, the most Famous being "Messiah." Even though Handel's works were written more for musical performance than for worship, the medium of music was prominently used to bring religious themes before the people. Throughout history Christians have praised their God in song and music.

Although using songs in worship is deeply rooted in history, no area of worship is more controversial than that of music. A discussion of the types of music appropriate for worship can bring more heat in an argument than can any other subject.

Rick Warren illustrates this fact when he relates a story of a popular current Christian radio personality:

James Dobson once admitted on his "Focus on the Family" program that "Of all the subjects we've ever covered in this radio program, from abortion to pornography to whatever, the most controversial subject we've ever dealt with is music. You can make people mad about music more quickly than anything else."”

${ }^{1}$ Schaeffer, 92.

${ }^{2}$ Warren, 284. 
Warren further says, "The debate over music styles has divided and polarized many churches. I guess that is why Spurgeon called his music ministry 'the War Department."'1 Current debates over music include topics such as music from the classical composers versus contemporary songwriters, vocal or instrumental (there are some critics who claim that since words cannot be understood when instruments are played, purely instrumental music should not be used in worship), and acoustical versus amplified instrumentation. And for the more conservative of taste, drums are a definite abomination which have no place within a church.

Arguments about musical styles are largely based upon personal likes and dislikes. There will never be a complete consensus of opinion--it will be impossible to please all worshipers on the topic of music for worship. As Hannum states:

No one kind of music meets the needs of all kinds of people. According to his background, culture, and training, an individual comes to associate particular religious feelings with particular kinds of music. Some will feel that the Gregorian chant, or plainsong, is the best religious music and that it expresses their religious feelings móst adequately. Others will get no good from this music. To still others there is nothing to surpass the gospel songs or spirituals for their religious expression. ... It is not wise to say dogmatically that only a particular style of music has the approval of God and should be used exclusively by the church. God has not seen to give us instructions to this end. ${ }^{2}$

Hannum further states:

The selection of music for religious services is not a matter of right or wrong. It is a matter of culture and taste. Tastes change and cultures differ. The goal is to use, as far as possible, the songs considered best in the culture in which one lives. Songs considered good and acceptable in the nineteenth century may have fallen into disuse today. Some songs in every era last for only a limited time. On

${ }^{1}$ Ibid.

${ }^{2}$ Hannum, Music and Worship 11. 
the other hand, some songs endure for centuries because they possess the timeless qualities which appeal to all men. Our objectives should be to use material which is in the best taste today. ${ }^{1}$

Each individual is a product of what I have termed the "Unique Person Syndrome," the combination of personalized factors including race, culture, heredity, education, and personality. As a result no two individuals have exactly the same tastes. People need to be reminded that styles and customs in music change with each generation. Even the great Johann Sebastian Bach was considered "as something of an out-of-date old man" by his composer sons. ${ }^{2}$ A plea for balance, tolerance, and respect for others must be made.

This plea for tolerance would extend even into the delicate area of contemporary religious music. Today's Christians are not the first generation that has argued over musical styles that are appropriate for worship. "Worship wars" over music have occurred for centuries. It is time that these hostile differences of opinions end.

As was previously stated, our goal for worship is to blend the best of the traditional worship practices with the best of the modern. But in the area of music this practice becomes difficult because the verdict is still out on much of contemporary Christian compositions. Normally it takes about ten years to incorporate a generation's musical contributions into the established Christian community. This leads to criticism upon the part of traditionalists and frustration by contemporary musicians and composers

${ }^{1}$ Ibid., 90, 91.

${ }^{2}$ Charles. R Hoffer, The Understanding of Music (Belmont, CA: Wadsworth Publishing Co., 1967), 161. 
who want to express their religious convictions in their own artistic patterns. Neither side is well-served by the attitudes which are displayed.

There is no easy solution for this dilemma. Yet it must be understood that each generation reevaluates worship practices and customizes them for use in its own setting and time. Especially is it vital for adult generations to encourage the youth to learn to express themselves in their own meaningful ways. If more time were spent in encouragement, there would be less time spent in arguing. Again, a plea for tolerance and understanding must be made.

Even though different individuals will have specific preferences in the area of music, songs that are used for worship must be chosen based upon certain principles as well as musical taste. An investigation of the previously cited biblical examples of music gives Christians a basic guideline in choosing music for worship--music was human praise given to God in response to an encounter with the divine power. Examples include the songs of Moses and Miriam which praise God for His power of deliverance from the Egyptians. ${ }^{1}$ And the songs featured in Revelation utter praise to the One whose power gives salvation through the sacrifice of the Lamb. ${ }^{2}$ Musical praise demonstrates humanity's loving response to a loving and giving God:

Franklin Segler comments on the significance that music has upon a congregation in worship:

${ }^{1}$ Exod 15.

${ }^{2} \operatorname{Rev} 5$. 
The purposes of music in worship are to create an awareness of God and a mood for worship, to enhance the inner life of worshipers, to unite the congregation for a worship experience, and to express the convictions of the congregation. Music may bridge our convictions with our feelings and attitudes. ${ }^{1}$

A major issue in the area of worship reform is the comparison between the "objective" and the "subjective" in worship. Perhaps no area in the overall topic of worship better illustrates the tension and relationship between these two than does music.

The "objective" aspect of worship places God as the center of worship, the "object" of all that is done. Objective worship magnifies God and emphasizes His divine aspects, such as His omnipotence, His omniscience, and His omnipresence. All of humanity's worship is directed upward toward God. Segler comments about the objective by saying,

In its objectivity, worship is directed away from us and toward God. The acts of God in history are primary in our worship. We are concerned about the historical facts, the revealed truths, and the person of God as manifested in Jesus Christ. These facts are objective to us. ${ }^{2}$

The "subjective" in worship places the focus on the human element. Worship becomes a personal experience in which emotions and feelings play an integral part. God is still adored for who He is but the focus of worship becomes the experience of divine power by those who worship. The basis of worship is to appreciate what God has done in and for humanity.

To focus exclusively upon either the objective or subjective to the neglect of the other is a dangerous trend for worship. An overemphasis upon the objective can de-

$$
\begin{aligned}
& { }^{1} \text { Segler, } 92 . \\
& { }^{2} \text { Ibid., } 65 .
\end{aligned}
$$


personalize God and make Him insensitive to human needs. However, to place emphasis completely in the realm of the subjective is to make feelings the basis of salvation. A balance between these two should be the ideal, emphasizing both the objective and subjective aspects of Christian worship. As Rayburn says, "If the primary emphasis of our worship is the magnification of God, and the movement of the service is Godward, we can expect that there will be notable subjective results in the lives of the worshipers."1

Music well delineates these two areas in the usage of hymns and gospel songs. The objective thought of worship flows through hymns, which illustrate the might, majesty, and power of God, whereas gospel songs relate a more subjective experience of how God's power has affected the worshiper's life.

Two of the most notable composers of hymns are Isaac Watts (1674-1748) and Charles Wesley (1707-1788). Some of Watts's compositions include "I Sing the Mighty Power of God," "Before Jehovah's Awful Throne," "O God, Our Help," and "Joy to the World." Some of Wesley's best-loved works include "Hark! The Herald Angels Sing," "Christ the Lord Is Risen Today," "Rejoice, the Lord Is King," and "O for a Thousand Tongues to Sing."

Even though these are classic examples of compositions which emphasize the objective element in worship, it must be emphasized that those who are considered hymn writers did not focus exclusively upon the objective. Wesley's "Jesus, Lover of My Soul" also deals strongly with the subjective aspect of worship.

${ }^{1}$ Rayburn, 132. 
The gospel song is an American phenomenon, rooted in the worship of the frontier. As James F. White says, "Much of the music of the frontier focused on how one felt about God, not on what God has done for us. The first person pronoun loomed large in this hymnody of feeling."1

Rayburn gives a more detailed account of the origins of gospel music in the new world:

The outstanding contribution of the United States to sacred song is perhaps the gospel song, which largely grew out of camp meetings and similar gatherings and then was widely used throughout the English-speaking world in the great evangelistic campaigns of D. L. Moody and Ira Sankey and today in the huge crusades of Billy Graham. ${ }^{2}$

These works emphasize the personal reaction of the believer to the salvation given by God.

One of the best-loved and prolific composers of gospel songs was Fanny Crosby (1820-1915). Some of her works include, "Blessed Assurance, Jesus Is Mine!," “Jesus Keep Me Near the Cross," "Redeemed!," "Draw Me Nearer," and "Tell Me the Story of Jesus."

If a poll was taken among believers as to which are the best-loved songs in the Christian world, many of the gospel songs would rank very high. These songs are intensely personal and reflective about the Christian's relationship with God.

${ }^{1}$ James F. White, A Brief History of Christian Worship, 172.

${ }^{2}$ Rayburn, 237. 
Not all liturgical scholars would agree with this sentiment, believing that these songs overemphasize the subjective area of worship. Rayburn is a good example of one who believes this type of music is ill-suited for Christian worship:

While these songs have been a blessing to multitudes, they are much more appropriate for evangelistic mission and for informal occasions than they are for the worship services of the church. [It is] my deep conviction that the evangelicals of this country need to be instructed in worship. Their common worship needs to be enriched, and a significant part of this enrichment could come from a better understanding and use of the great hymns of the church. ${ }^{1}$

This is a controversy which is unnecessary, and the Christian community is not well-served by any polarization between the objective and the subjective elements in worship. Biblical evidence indicates that both of these elements were present in worship experience in the Scriptures, e.g., the songs of Moses and Miriam. Again, a plea for balance must be made, and Segler states this balance well by saying, "Worship is an objective-subjective experience--objective because we think about God, subjective because we think about ourselves. A balance of the two is realized in genuine communion with God."2

In the area of the objective-subjective, the SDA church has reached a good balance in an official way. A survey of the Seventh-day Adventist Hymnal indicates that both hymns and gospel songs are well represented. The selection of hymns includes twenty-five

${ }^{1}$ Ibid.

${ }^{2}$ Segler, 64. 
from Isaac Watts and nineteen from Charles Wesley. ${ }^{3}$ The leading composer of gospel songs is Fanny Crosby, who has nineteen of her songs included in this collection. ${ }^{1}$

What are guidelines for choosing music? How is a balance between new and old achieved? It must be stated once more that there are many opinions expressed on the topic of music, and that a firm consensus is difficult to achieve. But guidelines for music must be based upon theology, not methodology. What are some principles for choosing music which will bring ultimate honor to God?

Harold Hannum asks a series of questions to help in the choice of music. These questions include,

How does my choice of music affect my spiritual life? Does the music exalt and glorify God? .. . Is the music primarily entertaining and pleasing to me, or does it lead me to contemplate spiritual themes? Does the music seem appropriate to the atmosphere of the church and does it promote the worship mood? ${ }^{3}$

Questions like these deserve serious thought when choices must be made for music to be used in Christian worship.

If guidelines such as these were more carefully considered, there would not be as many wars over music that is used in our churches. Christians must avoid the temptation of an aesthetic snobbery that comes in demanding that their choices in music must be adhered to. There is much to commend about the great music that has endured the

\footnotetext{
${ }^{1}$ Seventh-day Adventist Hymnal (Washington, DC: Review and Herald Pub. Assn., 1985), 813.

${ }^{2}$ Ibid., 811.

${ }^{3}$ Harold B. Hannum, Let the People Sing (Washington, DC: Review and Herald Pub. Assn., 1981), 18.
} 
passage of time, and the church must never desert the heritage that it has been given.

However, it must also be realized that there are minds which are just as creative today as were those of Bach and Handel. The best usage of music is to strive for a balance by using the greatest that each era, including the modern, has produced.

Again I must emphasize that I heartily support Robert Webber's position about worship where he says that the ideal philosophy of worship is to incorporate the best of the old traditions with the best of the new. ${ }^{1}$ The issue of religious music gives the church an outstanding opportunity to practice this philosophy.

In summary, music chosen for worship must be chosen to glorify God, not to be a concert for the ones presenting it. All music should be theologically correct and reflect the true biblical teachings about God and His character. The music should be aesthetic to the ear and easy for the voice to sing. Musical selections should be appropriate for the cultural setting in which they are presented. And, above all, music should enhance and deepen each worshiper's relationship with God.

\section{Prayer and Worship}

Although human beings communicate with each other through many ways, the most common is through the spoken word. People talk with each other, and by speaking together relationships are formed and strengthened. The act of speaking is so important that the Scriptures use the example that the Savior, Jesus Christ, was the Word of God. ${ }^{2}$

\footnotetext{
${ }^{1}$ Webber, 110, 111.

${ }^{2}$ John 1.
} 
Ellen G. White says that "He [Jesus] was the Word of God--God's thought made audible." The art of using words is a high form of communication.

Prayer is one of the most frequently used and most important elements in worship. Humanity speaks to God in words of prayer. Segler rightly terms prayer "The soul of worship."2

When sin entered this world the human race lost the ability to speak to God on a face-to-face basis. But it is still possible for humanity to communicate to divinity through prayer. Prayer is speaking words to the Creator and the Redeemer. It is a personal interaction with God.

The act of praying is demonstrated throughout the Bible. One of the many examples is that of Daniel, who, even though praying to a god other than the king of Babylon was forbidden on the penalty of death, went to his normal place of individual worship and addressed his prayers three times each day to the God of heaven. ${ }^{3}$ As Ellen G. White says, "Prayer is the opening of the heart to God as to a friend." Prayer is personally speaking to the best friend humanity could ever have.

In worship, however, the emphasis on prayer transcends personal communication with God--the interaction with heaven is by the corporate body of believers. At designated points in the service an individual will address God on behalf of those who are

${ }^{1}$ Ellen G. White, The Desire of Ages, 19.

${ }^{2}$ Segler, 99.

${ }^{3}$ Dan 6.

${ }^{4}$ Ellen G. White, Steps to Christ, 93. 
assembled. In an SDA worship service these prayers will normally include an invocation at the beginning of the service, a prayer to bless the collected offering, the main prayer of intercession (or "pastoral" prayer), and the benediction (which may be either a prayer or a blessing). As need arises there may be other prayers to bless a baptismal candidate, a dedicated child, or a special need for God's intervention in the life of the church body.

As there are many types of prayer in worship there are also many forms specific to the denominational liturgical practice. Protestants who use prayer books as worship aids, such as Episcopalians, Presbyterians, and Lutherans, will find prayers listed in their worship books to be read at specific times during the service. Other Protestant churches, SDAs included, have more of a "free church" practice which makes prayer more extemporaneous. Yet even in those churches that practice a more spontaneous attitude toward prayer, it is not uncommon for some prayers to be prepared ahead and then read to the congregation.

The biggest apprehension I have in the area of prayer is not as much the manner of praying (spoken or read) as the concern for the attitude on the part of the one who presents the prayer. There is always a possibility that prayer can become mechanical and trite. Prayers can become formal, ritualistic, and meaningless unless major care and concern are given to the place of prayer within the service.

Robert Williamson gives guidelines of common faults to avoid in public prayer. These include: lack of preparation, excessive length, poor delivery, monotonous references to the deity, personal references, preaching disguised as prayer, and private rather than public prayer. Items desirable for public prayer include: corporateness, fervor, 
reasonable length, freshness in thought and language, concreteness, progression, expectancy, and dedication of life as the goal. ${ }^{1}$

This lack of preparation for prayer is the major reason prayer becomes an empty ritual for too many worship services. Too often services focus upon the number and quantity of prayers as opposed to the quality of prayer. If prayer is direct speaking to God in the same manner as one would to a friend, should not prayers indicate that the one praying has a connection with heaven? Our prayers should indicate a deep and dynamic relationship with God.

If any denomination or individual church congregation is yearning for worship renewal, let the renewal begin in prayer. Acts 2:42 tells of four areas concentrated upon by the New Testament Christians, one of them being prayer. For prayer to be effective in a public worship setting it must be practiced individually by the members of the congregation during their own personal worship. A revival of prayer, the direct communication with God, will be the greatest step in the process of worship renewal.

\section{The Bible and Worship}

SDAs follow the Protestant tradition that the Bible is the basis of all the teachings of the church. Their official position about their reverence for the Bible's authority is strongly worded in their doctrinal beliefs:

The Holy Scriptures, Old and New Testaments, are the written Word of God, given by divine inspiration through holy men of God who spoke and wrote as they were moved by the Holy Spirit. In this Word, God has committed to man the knowledge necessary for salvation. The Holy Scriptures are the infallible

\footnotetext{
${ }^{1}$ Robert Williamson, Effective Public Prayer, quoted in Pease, 68.
} 
revelation of His will. They are the standard of character, the test of experience, the authoritative revealer of doctrines, and the trustworthy record of God's acts in history. ${ }^{1}$

The Word of God is the standard that SDAs use as their rule of life.

It would seem that SDA worship services would reflect this appreciation for the Scriptures, and that the Bible would be often featured as congregations meet before God. However, Pease poses an interesting question when he asks, "Revering the Bible as we do, isn't it strange that we sometimes neglect the Scripture reading in our worship services?"2 To imply that the Bible does not have a major portion of the worship service sounds heretical for SDAs. After all, do not most services include a Scripture reading? And some even include a Scriptural call to worship. But my personal observation is that the reading of the Scriptures is too often merely an afterthought for worship. Very little emphasis is placed upon a reverential reading of God's Word.

Again, SDAs are not alone in their worship practices--this lack of emphasis upon the reading of Scriptures is a phenomenon that is common in other churches as well. As Segler says,

The Free Churches boast, "We are a people of the Book," and yet there is great neglect of the Bible. People fail to read it regularly in private; in many homes the Scriptures are rarely read. Even in public worship services the reading of the Bible is often neglected. When it is read, it is often read carelessly and hurriedly. ${ }^{3}$

${ }^{1}$ Seventh-day Adventists Believe .... (Hagerstown, MD: Review and Herald Pub. Assn., 1988), 4.

${ }^{2}$ Pease, 66.

${ }^{3}$ Segler, 110. 
If the Bible points to Jesus Christ as the basis for human existence, it must be of primary importance for the worship experience--for individuals in their personal devotional study and for congregations as they worship together as corporate bodies.

The Word of God was of utmost importance to His people in the biblical record. A reform began in the time of King Josiah when he read the book of God's Law to his people. ${ }^{1}$ After the Babylonian captivity, as the Israelites were being restored to their land, Ezra stood before the people and read the Word of God. ${ }^{2}$

During His life Jesus used the reading of Scriptures as an act of worship. Upon returning to His home town of Nazareth He went into the synagogue where He stood to read the Scriptures. When He applied the meaning of Isaiah's words to Himself the townspeople tried to push Him over the edge of a cliff. ${ }^{3}$ Even their actions of rejecting Jesus demonstrated the great power in God's Word.

I believe that SDA worship services need graphic demonstration of the power that would come to them as a people if they would incorporate a more active reading of the Word in their worship. There are several methods which could be used. One which is common to many Protestants would be to choose two Scripture lessons, one from each the Old Testament and the New Testament, that would be read during the service. Another method (basically foreign to the SDA Church) would be to incorporate the use of a lectionary that would give specific readings that would follow the cycle of the religious

\section{${ }^{1} 2 \mathrm{Chr} 34$.}

${ }^{2}$ Neh 8:5-8.

${ }^{3}$ Luke 4:14-30. 
year. The hymnal published and used by the SDAs has an extensive section of Scriptures that can be read in a responsive manner by the congregation. However it is accomplished by each congregation, there must be a stronger emphasis upon the Word of God.

The reading of the Scriptures is not to be just another element in the worship--it must be done with the dignity that the Book deserves. It is not easy to find those who are proficient in the reading of the Bible for public worship. As Segler says, "To read the Bible well is a rare accomplishment. Good preachers are more numerous than good readers of the Scriptures." They should be read with good enunciation, with feeling, and with clarity. The stories of the Bible must come alive to the congregation in worship. To read the Bible well is an art, and it is an art that must be cultivated if the power of the Word is to be experienced.

\section{The Sermon in Worship}

If spoken words are the primary method through which humans transfer information to one another, the medium of communication most often associated with Christian worship is that of the preaching of the sermon. In a corporate setting the most anticipated words should be when the minister addresses the congregation with a message given to him from heaven. For many Protestants, SDAs included, the portion of the service devoted to the sermon is the central part of the worship time.

The act of preaching has a strong biblical precedent. Throughout the course of history God has used human beings to instruct His rebellious children the principles of

${ }^{1}$ Segler, 111. 
heaven. The medium of preaching has always been instrumental by God to bring a message to His people. Only a few examples of biblical preachers include Noah, ${ }^{1}$ Elijah, ${ }^{2}$ Jonah, ${ }^{3}$ John the Baptist, ${ }^{4}$ and, the ultimate preacher, Jesus Christ. ${ }^{5}$

The Apostle Paul emphasizes the importance of the orally communicated Word by asking a series of questions: "How, then, can they call on the one they have not believed in? And how can they believe in the one of whom they have not heard? And how can they hear without someone preaching to them?" (Rom 10:14). Preaching is the most commonly used medium through which the message of God is presented.

Preaching is different from any other form of oral communication. The primary purpose of preaching is not to lecture. As Pease says, "Really good preaching is the exposition of the Word of God for the purpose of revealing the Gospel of Christ andbringing men to accept the claims of Christ." And as James F. White states:

"Preaching is a form of communication based on the conviction that God is central in the process. The preacher speaks for God, from the scriptures, by the authority of the church, to the people."7

${ }^{1}$ Gen 6, 7.

${ }^{2} 1 \mathrm{Kgs} 18$.

${ }^{3}$ Jonah 3:4.

${ }^{4}$ Matt 3:1.

${ }^{5}$ Matt 4:17.

${ }^{6}$ Pease, 88.

${ }^{7}$ James F. White, Introduction to Christian Worship, 157. 
There are different words used for preaching in the New Testament. In his classic book on homiletics, John Broadus gives a good comparison between three of them:

The general term for preaching in the New Testament is $\kappa \eta \rho v i \sigma \sigma \epsilon l v$, to proclaim or herald. Another word, $\epsilon \dot{v} \alpha \gamma \gamma \epsilon \lambda \dot{i} \zeta \epsilon \sigma \theta \alpha l$, emphasizes the nature of the proclaimed message as good news. A third word, $\delta \imath \delta \alpha \sigma \kappa \epsilon \iota v$, is used to indicate the purpose of imparting to men divine truth and instructing them in righteousness. ${ }^{1}$

Some scholars want to make a major differentiation between the concept of "preaching," referred to most often by the word kerygma, and "teaching," which is the didache. ${ }^{2}$ As C. H. Dodd comments, "While the church was to hand on the teaching of the Lord, it was not by this that it made converts. It was by kerygma, says Paul, not by didache, that it pleased God to save men."3 However, Henry Grady Davis disputes this distinction and says that this separation is not understood in our modern era. He states: "It is used to cover all forms of speech in the public ministry of the church, and in that ministry proper teaching and exhortation are of course included." ${ }^{\prime 4}$

In the Christian church the power of the pulpit has often indicated the strength of the church. Ministers have been measured by their ability to preach. This has also been true in the SDA church. James S. White, one of the founding fathers of the SDA church, makes an interesting statement about the quality of preachers:

${ }^{1}$ John A. Broadus, On the Preparation and Delivery of Sermons (San Francisco: Harper and Row, 1870), 4. 106.

${ }^{2}$ Henry Grady Davis, Design for Preaching (Philadelphia: Fortress Press, 1958),

${ }^{3}$ C. H. Dodd, The Apostolic Preaching (Chicago: Willet, 1937), 8.

${ }^{4}$ Davis, 106. 
God pity the world that it has so many putty-faced, dilly-dally, second and thirdrate preachers. They may excel in those "good long" afternoon visits, and be eloquent with the knife and fork at the tea table, but in the speaker's stand, as the Californians say, they "pan out" small. ${ }^{1}$

Yet, not everyone agrees that preaching is of prime importance to the church. There are some who feel it is archaic and unneeded in today's modern society. Haddon Robinson reports on this attitude by saying, "The word is out in some circles that preaching should be abandoned. The moving finger has passed it by and now points to other methods and ministries that are more 'effective' and in tune with the times."2 Robinson does not believe in this trend of society. He emphasizes the importance of preaching and the effect it has upon Christians by saying, "Something awesome happens when God confronts an individual through preaching and seizes him by the soul."3

Preaching is different from any other form of public address--it brings a message from the Creator to the created, demanding decisive action upon the part of the listeners. Preaching compels decision, the same response that Peter's Pentecost sermon brought when the people cried out, "What shall we do?" (Acts 2:37).

Since preaching is so important, there must be some guidelines as to what makes a good sermon. Because there are numerous books which discuss this topic in detail, I will only summarize several principles for preaching which I have learned from years of reading and practical experience in sermon preparation and delivery.

${ }^{1}$ James S. White, "Reflections by the Way," Review and Herald, Oct. 7, 1875, 4. 1980), 15.

${ }^{2}$ Haddon W. Robinson, Biblical Preaching (Grand Rapids, MI: Baker Book House,

${ }^{3}$ Ibid., 19. 
A sermon must take its authority from the Word of God. The Bible must be primary in preaching. The example of the temptation of Jesus is the best model when $\mathrm{He}$ met Satan one-on-one with the words, "It is written" (Matt 4:4, 7, 10). The Word of God gives the preacher authority.

Preachers are to bear testimony to what they know through personal experience. As the Apostle John explained to his audience, "We proclaim to you what we have seen and heard" (1 John 1:3). For a message to be effective the Word of God must be allowed to impact the life of the preacher.

A sermon must be in language which the congregation understands. Again, the example of Jesus is a good one to follow, where He took eternal truths and taught in parables which illustrated His heavenly principles in words that His audience could comprehend. The sermon time in the worship hour must never be a time to flaunt the knowledge and vocabulary of the preacher.

Preaching must uplift Christ. The power in the message comes only as the words point to the cross of Christ. Jesus spoke of this power when He said, "But I, when I am lifted up from the earth, will draw all men to myself" (John 12:32). After hearing the Word of God the hearts of the congregation should burn as did the hearts of the two disciples as they accompanied Jesus on the Emmaus road. ${ }^{1}$

And, finally, preaching demands decision. The example of Pentecost has already been cited where, as a demonstration of the Spirit's power on Peter's words, three

${ }^{1}$ Luke 24:32. 
thousand people joined the church that day. ${ }^{1}$ Preaching is to impact people's lives in a way that they are drawn into a closer and deeper relationship with God. Every sermon should inspire Christians to respond more deeply in loving obedience to the revelation of God that they have witnessed through the delivered Word.

${ }^{1}$ Acts 2:41. 


\section{CHAPTER 5}

\section{IMPLEMENTATION OF THE PROJECT}

In considering this project on worship, three basic goals and objectives stimulated its inception. The first was to have an opportunity to study in a more intense way a topic that has always held a deep fascination for me. I wanted to increase my personal knowledge about this subject.

The second goal was to create a seminar on worship education to be used for my local congregation. It has been a desire of mine to develop a seminar to educate a local church congregation on basic biblical principles of worship. The culmination of the development of this program is the syllabus on the principles of worship, which is included in Appendix 2. The description of the evolutionary process of this syllabus is the focus of the first part of this chapter.

The third goal of this study was to create an order of service which will lead the congregation in its worship. It is my belief that the progression of the worship elements in an orderly way can contribute to the weekly spiritual experience of the worshiping community. A comparison of several examples of different orders of service is listed in Appendix 3. This portion of the study also examines the subject of how to make a 
worship service distinctive for SDA congregations. A report on this process is the second portion of this chapter.

\section{The Development of the Worship Education Seminar}

For many years it has been my desire to share with the members of my church the biblical principles of worship which I have learned from my personal study. After searching in vain for a manual on worship that could be adapted for my local congregation I decided it best to develop one myself.

SDAs usually break their year into three-month segments called "quarters." These are thirteen-week periods around which their Sabbath School curriculum is divided. In developing a worship seminar, one of my ambitions was to organize the material into thirteen lessons for easy adaptation to this quarterly concept. This would make this seminar flexible for use in a Sabbath School educational setting.

The seminar syllabus, a copy of which is contained in Appendix 2, closely parallels the material contained in chapters 2,3 , and 4 of this paper. The syllabus covers a brief biblical and historical study of worship principles through the ages. It also includes information about some of the main elements of worship, including music, prayer, the reading of Scripture, and the sermon. The seminar was presented in an evening series of meetings from April 7, 1998, to June 30, 1998, in the College Place Village Church in College Place, WA. 
Overall the seminar went very well. The material seemed easy to understand and the majority of those who attended regularly said they received a deeper knowledge and understanding of the true meaning of worship.

To try and measure the knowledge and attitudes about worship a survey was taken at the opening and closing sessions of the seminar. Twenty-five people agreed to participate in answering the questions in the surveys. These members represented a cross-section of ages within the congregation of the Village Church. A copy of the survey and its results are listed in Appendix 1.

The variety of answers which the survey produced reinforced a major premise I had discovered in my years of pastoral ministry--there is an unfortunate widespread ignorance among the majority of SDA church members about this topic. This lack of knowledge is most evident in general areas of worship principles. For example, what is the purpose of worship, and must SDAs follow the "official" order of service as listed in the Church Manual?

Not surprisingly, the survey showed that there were distinct opinions expressed among the different elements of worship. For example, the majority thought that prayer language should be modern instead of the King James vocabulary. Music is definitely "religious" or "secular"--there is not much middle ground on that topic. And prayers should be carefully planned, and it is appropriate to read these petitions to God.

A comparison of attitudes and knowledge at the close of the seminar revealed that the strong opinions about the worship elements remained basically the same. For example, attitudes about music are quite firmly set that there is definitely a type of music which is 
appropriate for worship. And the majority of members appreciate the prayers in a language which reflects their current vocabulary instead of the time of King James.

The biggest attitude change occurred in the area of SDA distinctives in worship. As a result of their study more members believed that the doctrines of the Sabbath, the second coming of Christ, and the sanctuary should be featured on a more frequent basis. There was a stronger desire to make SDA worship services more focused on that which makes the denomination's message unique.

Although the survey did indicate trends about worship preferences, a few words of evaluation of the survey are appropriate at this time. If I had the opportunity to use the survey again there are several major changes which I would make. Since the survey was aimed to measure knowledge and attitudes, I would now revise it to be more specific in what knowledge and attitudes were to be measured. Most of the questions dealt with the mechanical aspects of worship rather than the biblical principles of worship. If I were to compose a new survey I would include sections on both principles and concepts of worship and also the mechanical aspects of how a worship service is organized.

I would also choose the target group more carefully. Although the group surveyed was a good cross-section of those who attended, they were not really a good cross-section of the church family. To get a more representative group from the church I should have included more young adults and some teens to receive their input. And I also could have used a larger portion of the congregation instead of only twenty-five individuals from a congregation that has almost two thousand members. The next opportunity that I have to 
present this seminar these principles will be incorporated as I try to evaluate the success of my worship program.

\section{The Development of the Order of Service}

The name "Seventh-day Adventist" illustrates two major and distinctive doctrines of the denomination. The SDA church was birthed from a movement in the nineteenth century that emphasized the nearness of the second coming of Christ. Under the leadership of William Miller, a Baptist, the "adventists" preached that the return of Christ would be "soon." From their understanding of the biblical prophecies of Daniel and Revelation, these believers eventually decided that the second "advent" of Chrịst would occur on October $22,1844 .{ }^{1}$ During this time a number of their believers also became convinced that the day of worship had never been biblically changed from the seventh day of the week to the first. The number of believers who accepted both teachings continued to grow. In 1860 the denomination was organized and "Seventh-day Adventist" was officially adopted as its formal name. ${ }^{2}$

Since the membership of the SDA church was originally comprised of Christians from many different denominations there has never been one set pattern of worship that was distinctly SDA. Modern SDA worship practices are very similar to many other Protestant denominations. Their services include music, prayer, and the reading of the

${ }^{1}$ C. Mervyn Maxwell, Tell It to the World, rev. ed. (Boise, ID: Pacific Press Pub. Assn., 1977), 31.

${ }^{2}$ Ibid., 145. 
Scriptures. The pulpit is centrally located on the platform of an SDA sanctuary, indicating the centrality of the exposition of God's Word in worship.

Should SDA worship be different from other churches, or is traditional Protestant worship acceptable for them? Is there anything that is distinctive in SDA teachings and doctrines that should be highlighted in their worship practices? It would seem logical that SDA liturgical scholars would examine this issue.

Norval F Pease, who wrote the pioneer volume on worship titled And Worship Him, addresses this topic only in a general way. His comment is that SDA worship services should be "Biblical, evangelistic, and reverent."1 The focus of his concern, penned in the wake of the liturgical revival that occurred in the 1960s, is for SDAs not to forsake their Protestant roots and turn to more highly liturgical and formalized patterns of worship. ${ }^{2}$ Although Pease did a commendable job in this volume, it only scratches the surface of the topic of worship.

A second SDA liturgical scholar, C. Raymond Holmes, addresses the issue much more thoroughly and theologically than does Pease in his book entitled Sing a New Song. In 1991, during the "Celebration" crisis, Holmes summarized the status of worship in the SDA church by saying, "Failure to develop a philosophy (theology) of worship has led to liturgical borrowing from other denominations, either of the highly formal variety or now the charismatic variety." 3

${ }^{1}$ Pease, 51 .

${ }^{2}$ Ibid., 38.

${ }^{3}$ Holmes, "Searching for Genuine Adventist Worship," 30. 
The SDA denomination, to its detriment, has never directly dealt with a theology of worship.

Holmes comments that most SDA worship services are not easily distinguished from other denominations. He states: "In most cases, unless the sermon deals with doctrines unique among Adventists, the service could easily be that of a Baptist, Methodist, or Presbyterian church. But a proper Adventist liturgy is one that reflects Adventist beliefs." And Holmes further clarifies his thoughts by saying, "There are three distinctive doctrines which ought to be illustrated liturgically in every Adventist church's worship service: the Sabbath, the heavenly ministry of Christ, and the second Advent of Christ."

Although Holmes does leave the implementation of this to the creativity of pastors and worship leaders, ${ }^{3}$ he suggests the possibility of highlighting these three doctrines where "the introit will focus on the Sabbath, the prayer response on the sanctuary ministry of Christ, and the benedictory response of His second Advent." Holmes's goal is that this usage will constantly remind SDAs in worship of their distinctive message to the world.

I applaud Holmes for his efforts to make SDA worship distinctive, yet I have two personal concerns about his suggestions. The first concern addresses the use of the

${ }^{1}$ Holmes, Sing a New Song, 16.

${ }^{2}$ Ibid.

${ }^{3}$ Ibid.

${ }^{4}$ Ibid., 95. 
congregational responses, and the second concern is that he overstates the necessity of making certain that SDA worship is distinctly "Adventist."

My own experience with congregational responses is that they too quickly become mechanical, ritualistic, and so familiar that the meaning is lost for too many worshipers. To quote Howard Stevenson, who served as Charles Swindoll's minister of music, "The higher the predictability, the lower the impact." ${ }^{\text {To }}$ Toly upon congregational responses to signify distinctive Adventist worship reverts to relying on methodology for worship renewal instead of a theology of worship that responds in loving obedience to the revelation of God.

My second concern is that since SDAs are Bible-believing Christians, SDA worship should be services which Christians of other denominations should feel comfortable to attend. My personal preference to make SDA worship distinctive would be to highlight the entire life of Christ. Any service should somehow be a re-enactment of the life of Christ and should celebrate His life, death, resurrection, heavenly ministry, ascension, and second coming.

In this context the Sabbath signifies not only a memorial of God's creation, but also the Christian's rest in the assurance of salvation because of the sacrifice of Jesus. His current ministry in heaven emphasizes His intercession for humanity for the forgiveness of their sins. And believing Christians live in the blessed hope of His anticipated return. All of these can be illustrated through varied hymns, readings, and Scriptures as the worship

${ }^{1}$ Jack Hayford, John Killinger, and Howard Stevenson, Mastering Worship (Portland, OR: Multnomah Press, 1990), 28. 
service progresses. At the close of worship those who have attended should not only be more aware of the beauty of Christ's sacrifice for humanity, but also each worshiper's personal devotion to the Savior should be intensified and strengthened. The result of worship should be a deeper desire for service for the Master.

How these different elements are organized for worship is determined by the order of service. A typical plan for Protestants includes a progression from hymns, Scriptures, and prayers to the sermon, which is usually the climax for the worship service.

The SDA Church Manual gives two suggested orders of service. ${ }^{1}$ The basic order is one which is most commonly used not only in SDA churches, but in most Protestant evangelical churches as well. Because it is so well-known and often used I have been informed by members that it should be considered sacred and not deviated from.

An order of worship sets the flow for the worship hour by using certain elements which will create a progression of different moods within the service. John Broadus states it well: "There is no one way to arrange or to plan worship, but there are certain moods of worship and certain principles which will give guidance in planning."2

Naturally, different liturgical scholars suggest different numbers of these elements. Broadus gives a good example of the different moods as he suggests five parts of the order which will progress towards a deeper devotion to God. His suggestions include recognition, praise, confession, illumination, and dedication. ${ }^{3} \mathrm{~A}$ list of what comprises

\section{${ }^{1}$ SDA Church Manual, 66.}

${ }^{2}$ Broadus, 310 .

${ }^{3}$ Ibid., 310, 311. 
each of these elements for the Village Church order of service is found in Appendix 3. This order has served the church well and is easily adaptable to include any additional elements that may not be found each week in the worship hour, such as baby dedications or baptisms.

A word of caution must be stated at this point. Personal worship reflects the personality and customs of each individual because every human being is unique. It is the epitome of presumption for one individual to try and dictate to another how that person must worship God.

Congregations reflect this same individuality. In all the churches I have been privileged to serve in my almost twenty-five years of pastoral ministry, no two have been identical. Every congregation will have unique tastes in such elements as music and church architecture and will respond differently as the revelation of God is experienced.

No one style of worship will fit each individual and each congregation. Worship leaders must be challenged to evaluate the resources, needs, and abilities of the people whom they serve, and worship should be patterned and structured in ways which use these resources to instill a deeper appreciation for God.

SDAs are no different from any other denomination in the fact that there needs to be a measure of freedom and flexibility given to each member and congregation to express praise to God in individual ways. Yet, all Christians must remember that attempts to be innovative in worship practices, to change elements such as musical and liturgical patterns, is not the basis of worship reform. True worship renewal comes only as Christians individually and collectively experience God. Humanity worships God only as they 
respond to the revealed love of the Creator and Redeemer and give to Him the ultimate service and allegiance of their lives. 


\section{CHAPTER 6}

\section{CONCLUSIONS}

To enter into a study of the topic of worship is to experience a contrast of thoughts and emotions. It is a rewarding subject for exploration because it underscores the whole basis of the Christian experience--responding in loving obedience to the selfrevelation of a devoted and giving God. Yet, it is also a somewhat frustrating undertaking because the more one becomes immersed in this topic the more one comes to the realization how big and comprehensive it is.

As a result of exploring the subject there are several conclusions which I have made about SDAs and their worship practices. These conclusions are the basis of this chapter.

\section{SDAs Need to Develop a Theology of Worship}

In chapter 3 a theology of worship based upon the words "revelation" and "response" was discussed and developed. Christian worship centers upon the God who has revealed Himself as humanity's Creator and sinful humanity's Redeemer. Worship becomes the human response of loving obedience and service to God. As Christians grow in their religious experience they continually learn more of God's love as He constantly reveals Himself. And their response is to give lives of continuous service to Him. Thus, 
worship is synonymous with continual Christian growth. When viewed in this sense the study of worship becomes in reality the study of practical Christianity.

In chapter 5 SDA liturgical scholar C. Raymond Holmes was quoted as saying that the SDA church needs to develop a theology of worship. His conclusion is that the lack of this theology has resulted in SDA worship practices being blown by the winds of change, affected by society and also other churches. This underscores what I feel to be one of the greatest needs for SDAs--to present biblical principles of worship to SDA Christians and give this topic the priority it deserves. The leaders of the SDA denomination, from those on the highest administrative level to the pastors in the local churches, must be encouraged to become proactive on this topic of worship. Unfortunately, too often the members (and leaders?) of the denomination have only reacted to what they have viewed as crises situations.

For example, in 1991 a special issue of Ministry, the monthly journal for SDA clergy, focused upon the topic of worship. At first glance it would seem that this was a good attempt upon the part of the leadership of the denomination to discuss in an official way worship principles and practices. However, in reading this special edition of the journal it was obvious that the driving motivation behind its production was the controversy over different worship practices which were threatening to divide the denomination, not from a basic motivation of a need to educate the people. I say this because the years since this issue was published have produced only occasional articles in Ministry about worship--there has been no further major attempt to educate SDA pastors or members on this subject. 
It is time that SDAs realize and implement the truth in David Watson's claim that "the primary task of the church is to worship God." This can happen only as church members are educated in the principles of worship, which is the focus for the next section.

\section{SDAs Must Develop a Systematic Worship Education Program}

One of the biggest conclusions that has been reinforced to me during the duration of this study is the ignorance among SDA church members on the topic of worship--the principles of worship are not generally known to the members. It is time that the SDA denomination placed the topic of worship higher on its list of priorities. Should not the study of worship receive equal treatment as the study of the Sabbath, the prophecies of Daniel and Revelation, and any other subject deemed important to the well-being of the church and the advancement of the Gospel?

I have a dream which I am afraid will never be fulfilled by the SDA denomination in an official capacity. I would envision that each local conference would develop a resource seminar about worship which would be made available for local congregations. This would be implemented by an individual from the conference office who would have a burden for this important subject.

The reason I am not optimistic about this dream being fulfilled is that it has not yet happened. In April of 1998 all the SDA pastors in the Pacific Northwest and Alaska met in Seattle for a pastors' conference. From Wednesday until Saturday many different seminars were offered on a variety of subjects, most of which were related to evangelism

\footnotetext{
${ }^{1}$ Watson, 179 .
} 
and church planting. The closest one seminar came to the topic of worship was how to include computerized presentations in the worship hour. It was definitely not focused on the biblical principles of worship.

I would hope that individual pastors would see the need for a renewal on this topic. Yet worship has not been highly emphasized in the training that most pastors receive. In my undergraduate work in theology there was no class offered on how to be a leader of worship. In the seminary I attended two classes on worship, one each on the master's and the doctoral level.

For this reason I have personally developed my own seminar on worship principles to be shared in the local congregation. I have presented it in a Wednesday evening prayer meeting session and plan to continue to do this every two years. I hope that at least those congregations will catch the value of the principles of worship.

\section{The Need for Planning by Worship Leaders}

As this paper is being prepared an interesting development about worship is taking place at the Village Church in College Place, WA. Even though the pastors have talked extensively on this subject, we have recently spent two sessions at our weekly staff meetings discussing the worship order and making plans to further revise the Sabbath morning services. Although the basic order will remain similar to what is currently shown in Appendix 3, some fine-tuning is being considered in order that the different elements, especially prayer, can have a greater impact in the worship practices of the congregation. 
During the discussion I commented that the implementation of these concepts would place an added challenge in that the committee would be mandated to spend much more time in planning the service. And this illustrates what I feel is a great need in too many SDA services--the need for planning.

I have personally spent almost twenty-five years in the SDA pastoral ministry. During this time I have learned by experience that successful services are not a product of chance, that much time and thought must go into the preparation of worship by the leaders. No matter what size the church may be, there is a need for a worship committee to plan the worship services. The chosen individuals should coordinate every weekly service in ways which will make worship a joy for members to participate in united praise to their God.

\section{The Need for Preparation by the Congregation}

But, what of the congregation? Do they share any burden about the necessity to plan and prepare for worship? Or do the majority of members feel that worship is an event that just happens, and that all they need to do for involvement is to appear on Sabbath morning?

I propose that the challenge to improve SDA worship practices rests not only on the shoulders of those who prepare the order of service for the weekly worship hour, but it also rests in the hands and hearts of those who come to worship every Sabbath morning. The united corporate worship services should be a culmination of all the personal worship that is done by members each day of the week. Let me illustrate this by citing an example 
from the Sabbath School, the study time which precedes the worship experience in most SDA churches.

For this study time SDAs distribute booklets called "Sabbath School Quarterlies." These are given to members to study daily the chosen topic for the week. The teachers in the Sabbath School expect that their class members will acquaint themselves with the lesson before the designated discussion time on Sabbath morning. The goal is for the class to engage in an interchange of ideas and that all will participate together as they learn and grow through the study of God's Word.

That same dynamic should be present during the worship experience. Christian worship is not a spectator sport, it is the united Body of Christ interacting together with one another and with the head of the Body, Jesus Christ. A successful worship service is one where the members have experienced the grace and salvation of Christ individually and come together to mutually share their love for their Redeemer.

For members to pray together, they should first learn to pray individually. To sing praise to God as a corporate body members must first raise individual voices daily in heavenly praise. To hear God's Word together Christians should individually know the God of the Word.

Robert Webber is the author of a book entitled Worship Is a Verb. As the title would imply, his concern is to move worship away from the spectator mentality that too many Christians are mired in and shift to the active participant mode. In this book he 
gives eight principles for "participatory worship." The last of his principles is that worship is a way of life. ${ }^{1}$ He states:

Worship is central to all that we do. And for that reason our whole life is both a procession toward worship and a procession out of worship. Life is a cycle of constant return to the source of our new life and to the empowerment for life that we receive from the Christ that we meet and celebrate in worship. ${ }^{2}$

Worship thus becomes a full-time activity for the Christian and not just a hobby to occupy our leisure or discretionary time.

The Bible records many individuals whose dedication to God was complete and whose lives were devoted to constant worship of their Heavenly Father. A wonderful illustration of this principle is Daniel. When faced with his greatest crisis, King Darius commented to Daniel that the God whom the aged man served "continually"3 could save him from destruction by the lions. Daniel's life was a constant response of loving obedience to the self-revelation of the God of heaven. And in the New Testament Paul also speaks of this "worship of the life" by stating: "Therefore, I urge you, brothers, in view of God's mercy, to offer your bodies as living sacrifices, holy and pleasing to God-this is your spiritual act of worship" (Rom 12:1).

The challenge and mandate is very clear for all Christians. It is time for the church to make every act of living a continuous response of love and obedience to the God who unceasingly reveals His love for His creatures. When we as individuals and as a united 203.

${ }^{1}$ Robert E. Webber, Worship Is a Verb, rev. ed. (Nashville: Abbott Martyn, 1992),

${ }^{2}$ Ibid., 213.

${ }^{3}$ Dan 6:16, 20. 
Christian community make this the top priority in our lives, then we will have learned the true meaning of worship. 


\section{APPENDIX 1 \\ WORSHIP. SERVICE SURVEY}

Please indicate your response to the following questions by circling the appropriate number:

1-Strongly Agree

2-Agree

3-Neutral/Uncertain

4-Disagree

5-Strongly Disagree

1. The primary task of the church is to worship God.

2. God is very explicit about how we worship Him.

3. The Seventh-day Adventist Church has an official order of service which each church is encouraged to adopt.

4. Two activities each worshiper is encouraged to do in every worship 12345 service are to pray and to praise.

5. The doctrines we hold will determine the nature of the worship service.

6. The order of service should be suited for the specific congregation. 12345

7. Worship is not a performance we observe, but a service that we do. 12345

8. Music is neither religious nor irreligious.

9. Music played an important part in Biblical worship.

10. To pray in public one must first pray in private.

11. It is inappropriate for a prayer to be written out or read. 
12. The only correct posture for prayer is to kneel.

13. Elders should give the pastoral prayer, not the minister.

14. In prayer use "thee" and "thou" instead of "you" and "your."

15. A benediction should always be a prayer.

16. Classical music is always appropriate for worship.

17. Hymns should be easy to sing.

18. A Hymn of Meditation before the sermon helps set an atmosphere which makes concentrating on the sermon easier.

19. The giving of offerings is a form of worship.

20. Deacons should refrain from passing the offering plate to those on the platform to avoid embarrassing someone who has nothing to place in the plate.

21. The children's story is important to the worship service and should be a weekly feature.

22. The doctrines of the Sabbath, Sanctuary, and the Second Coming should be featured in every Seventh-day Adventist worship service.

23. Which is not a guiding principle for prayer?

1. Good style.

2. Delivered clearly.

3. Totally Spontaneous.

4. Addressed to God.

24. The benediction is:

1. The closing prayer.

2. A declaration of God's grace and care to the worshiping congregation.

3. A time to underscore the sermon's point.

25. Which is the most important factor in determining an order of service?

1. The size of the congregation.

2. The history of the church.

3. The facilities and resources of the church. 


\section{SURVEY RESULTS}

\section{START OF SEMINAR}

\begin{tabular}{|c|c|c|c|c|c|}
\hline & Strongly Agree & Agree & Neutral/Uncertain & Disagree & Strongly Disagree \\
\hline 1 & 11 & 7 & 5 & 2 & \\
\hline 2 & 12 & 9 & 2 & 1 & 1 \\
\hline 3 & 5 & 8 & 6 & 6 & \\
\hline 4 & 16 & 9 & & & \\
\hline 5 & 7 & 10 & 6 & 1 & 1 \\
\hline 6 & 5 & 9 & 8 & 2 & 1 \\
\hline 7 & 11 & 10 & 3 & 1 & \\
\hline 8 & 1 & 1 & 2 & 10 & 11 \\
\hline 9 & 10 & 13 & 1 & 1 & \\
\hline 10 & 12 & 6 & 4 & 3 & \\
\hline 11 & 2 & 1 & 7 & 10 & 5 \\
\hline 12 & & 1 & 4 & 13 & 7 \\
\hline 3 & & 4 & 9 & 8 & 4 \\
\hline 4 & 2 & & 7 & 10 & 6 \\
\hline 15 & 1 & 5 & 8 & 10 & 1 \\
\hline 16 & & & 4 & 16 & 5 \\
\hline 17 & 6 & 17 & 1 & 1 & \\
\hline 18 & 6 & 13 & 5 & & 1 \\
\hline 19 & 11 & 10 & 3 & 1 & \\
\hline 20 & 1 & 1 & 6 & 11 & 6 \\
\hline 21 & 7 & 10 & 5 & 2 & 1 \\
\hline 22 & 3 & 2 & 9 & 10 & 1 \\
\hline
\end{tabular}

\begin{tabular}{|c|c|c|c|c|}
\hline \multicolumn{1}{|c|}{$A$} & $B$ & C & D \\
\hline 23 & 17 & & 5 & 3 \\
\hline 24 & 17 & 6 & 2 & \\
\hline & 5 & & 20 & \\
\cline { 2 - 5 } & & &
\end{tabular}




\section{SURVEY RESULTS}

COMPLETION OF SEMINAR

\begin{tabular}{|c|c|c|c|c|c|}
\hline & Strongly Agree & Agree & Neutral/Uncertain & Disagree & Strongly Disagree \\
\hline 1 & 12 & 8 & 3 & 2 & \\
\hline 2 & 16 & 7 & 2 & & \\
\hline 3 & & & 6 & 9 & 10 \\
\hline 4 & 20 & 5 & & & \\
\hline 5 & 17 & 5 & 3 & & \\
\hline 6 & 10 & 11 & 4 & & \\
\hline 7 & 13 & 10 & 2 & & \\
\hline 8 & 2 & & 2 & 8 & 13 \\
\hline 9 & 10 & 13 & 2 & & \\
\hline 10 & 13 & 8 & 4 & & \\
\hline 11 & & 1 & 7 & 9 & 8 \\
\hline 12 & & 1 & 3 & 13 & 8 \\
\hline 13 & & 5 & 5 & 8 & 7 \\
\hline 14 & 2 & & 3 & 10 & 10 \\
\hline 15 & 1 & 3 & 5 & 9 & 7 \\
\hline 16 & & & 2 & 16 & 7 \\
\hline 17 & 16 & 8 & 1 & & \\
\hline 18 & 9 & 10 & 5 & & 1 \\
\hline 19 & 12 & 10 & 3 & & \\
\hline 20 & & 1 & 3 & 10 & 11 \\
\hline 21 & 8 & 10 & 5 & 2 & \\
\hline 22 & 13 & 8 & 4 & & \\
\hline
\end{tabular}

\begin{tabular}{|c|c|c|c|c|}
\hline A & B & C & D \\
\hline 23 & 8 & & 12 & 5 \\
\hline 24 & 9 & 16 & & \\
\hline & 2 & 1 & 22 & \\
\hline
\end{tabular}




\author{
APPENDIX 2 \\ WORSHIP EDUCATION SYLLABUS
}

CHAPTER 1

AN OVERVIEW OF WORSHIP

I. Worship is the most important activity of the church.
A. "The primary task of the church is to worship God." David Watson
B. "The first business, then, of a church is not evangelism, nor missions, nor benevolence; it is worship. The worship of God in Christ should be at the center of all else that the church does. It is the mainspring of all the activity of the church."
W. T. Conner

II. Worship comes from the Old English word Weorthscipe, and means, "To give ultimate worth to."

III. Worship is the central issue in the Great Controversy.

IV. "Again, the devil took him to a very high mountain and showed him all the kingdoms of the world and their splendor; and he said to him, "All these I will give you, if you will fall down and worship me." Matthew 4:8, 9 NRSV
A. "Fall down"-_"pipto"--To fall down from a higher point; to throw oneself to the ground as an act of devotion.
B. "Worship"--"proskuneo"--to fall down and worship, to do obeisance to, to prostrate oneself before, do reverence to, welcome respectfully.


C. The issue is clear--Satan wants the worship which is due only to God.

V. Worship will be the major issue in the last days. Revelation 14:6-12--The core of the Three Angels' Messages is worship.

VI. Worship is best defined as:

"Humanity's loving response to God's revelation."

A. "Because man is limited and God is superior to him in many ways, God must take the initiative in establishing the relationship."

Millard J. Erickson, ed., The Living God, 115, 116.

B. "Worship depends upon revelation, and Christian worship depends upon the revelation of God in Christ Jesus. Worship is therefore a revelation and a response which springs from the divine initiative in redemption. By faith we respond to grace as we find it in a face-to-face encounter with God."

Franklin Segler, Christian Worship, 48.

C. "God is worshiped for His own glory. Worship is man's loving response for God's personal revelation in Jesus Christ. Genuine worship takes place only when God is worshiped for His own sake."

James L. Christiansen, Don't Waste Your Time in Worship, 30.

VII. How God reveals Himself:

A. God reveals Himself as Creator--Only God can create something from nothing.

1. Genesis 1:1--The most powerful text in the Scriptures.

2. Psalm 19:1--Declares the general revelation of God.

B. God reveals Himself as the Redeemer.

1. $\quad$ Exodus 20:1, 2 .

2. Psalm 51:10.

3. Isaiah 6:1-8. 
4. Luke 19:10.

5. Revelation 5:14.

VIII. Each person responds differently to God's revelation. How we worship will be determined by:

A. Theology--The individual's view of God.

B. Sociology--The "Unique Person Syndrome."

1. Race.

2. Nationality.

3. Environment.

4. Personality.

5. Education.

IX. Summary: What is worship?
A. Recognition of the Creator.
B. Recognition of the Redeemer.
C. Acceptance of God's gift of salvation.
D. Responding in obedient love for what God has done. 


\section{CHAPTER 2}

\section{WORSHIP FROM EDEN TO THE EXODUS}

I. Worship before the Fall was enjoying God's gift of:
A. Sabbath--God gave a special time.
B. Himself--God gave His special presence.

II. After the Fall, worship also involved redemption through the promised Messiah.

A. Genesis 3:15--The promise of a Savior.

B. "Adam, in his innocence, had enjoyed open communion with his maker; but sin brought separation between God and man, and the atonement of Christ alone could span the abyss, and make possible the communication of blessing or salvation from heaven to earth. Man was still cut off from direct approach to his Creator, but God would communicate with him through Christ and angels." Patriarchs and Prophets, 67

III. Cain and Abel--Distinction was made between obedience and rebellion.

IV. Seth--The Father of Obedience.

A. "Seth also had a son, and he named him Enosh. At that time men began to call on [or to proclaim] the name of the Lord." Genesis 4:26 NIV.

B. "The faithful had worshiped God before; but as men increased, the distinction between the two classes became more marked. There was an open profession of loyalty to God on the part of one, as there was of contempt and disobedience on the part of the other."

Patriarchs and Prophets, 80. 
C. "In his time a more formal worship was begun. Men had of course called upon the name of the Lord before Enos' birth, but as time went on a more pronounced distinction arose between those who worshiped the Lord and those who defied him. The expression 'to call upon the name of the Lord' is used frequently in the OT to indicate, as it does here, public worship (Psalms 79:6; 116:17; Jeremiah 10:25; Zephaniah 3:9)."

SDA Bible Commentary, vol. 1, 244.

V. Enoch--Walked with God.

A. "Enoch lived in constant fellowship with God. "Enoch walked with God; and he was not, for God took him" (Genesis 5:24). The Hebrew word 'walked' suggests an intimate fellowship between Enoch and God. The literal translation says they 'walked back and forth together.' Enoch not only worshiped God at stated times, but he lived in continuous relationship with his Creator."

Franklin Segler, Christian Worship, 15.

B. "Enoch's walk with God was not in a trance or a vision, but in all the duties of his daily life. He did not become a hermit, shutting himself entirely from the world; for he had a work to do for God in the world. In the family and in his intercourse with men, as a husband and father, a friend, a citizen, he was the steadfast, unwavering servant of God."

Patriarchs and Prophets, 85.

C. "In the midst of a life of active labor, Enoch steadfastly maintained his communion with God. The greater and more pressing his labors, the more constant and earnest were his prayers. He continued to exclude himself, at certain periods, from all society. After remaining for a time among the people, laboring to benefit them by instruction and example, he would withdraw, to spend a season in solitude, hungering and thirsting for that divine knowledge which God alone cam impart. Communing thus with God, Enoch came more and more to reflect the divine image. His face was radiant with a holy light, even the light that shineth in the face of Jesus. As he came forth from these divine communings, even the ungodly beheld with awe the impress of heaven upon his countenance."

Patriarchs and Prophets, 86, 87 
VI. Noah.
A. Genesis 8:20-22--Worshiped God through sacrifices.
B. Genesis 9:8-17--The Divine-human covenant of the rainbow.

VII. Patriarchal Age.
A. Abraham worshiped by:
1. Genesis $12: 7 ; 13: 14-18$--Building altars.
2. Genesis 14:18-20--Paying tithes to God's priest.
3. Genesis 21:33--Planted a tree.
B. Genesis 24:48--Abraham's servant.
C. Genesis 28:18-22; 35:1, 14, 15--Jacob; "Bethel."

VIII. Summary:

"These incidents teach us something about worship in pre-Mosaic times. It was characteristically a response of a man to a personal encounter with God. Man worshiped, not to appease a God whom he feared but to express his gratitude and love to a God who had revealed Himself to him. The symbols were simple--an altar, a lamb, a rock, a tree, a pillar, a bowed head, a place called "the house of God." Worship was very personal and very real. God came close to man, and man's response was worship." Norval F. Pease, And Worship Him, 13 


\section{CHAPTER 3}

\section{FROM THE EXODUS TO THE BABYLONIAN EXILE}

I. The Exodus--The object lesson of God's redeeming power.

A. The decisive event in the Old Testament, which determined not only Israel's faith and practice, but also her worship, was the Exodus from Egypt. God's people experienced divine redemption from slavery in a foreign land. But, in a larger sense, this typified the deliverance of humanity from the larger slavery of sin. How humanity responds to that deliverance is called worship.

B. Christian worship can only be done by those who have personally experienced salvation.

C. "That which has always distinguished both Hebrew and Christian worship from the worship of any other religions in the world is the fact that the worship of God's people has always been the worship of those who have been redeemed. This means that true biblical religion always begins with what God has done and not what He requires of men or what men decide to bring to Him." Robert G. Rayburn, O Come, Let Us Worship, 52

II. The Sinai Encounter--God establishes His people as a worshiping community.

A. Exodus 20:1-7--The giving of God's Law:

1. God reminds the people how He revealed Himself as Redeemer.

2. The first four commandments deal with worship.

3. The worship of Israel was based upon theology:

a. The transcendence of God. 

b. The sinfulness of man.
c. The grace of God.
d. The necessity of forgiveness.

4. The Children of Israel were instructed in worship and ethics.

B. Exodus 24:1-8--Israel accepts God's terms.

1. The meeting was initiated by God.

2. The people participated.

3. The meeting was characterized by a proclamation of God's Word.

4. The Children of Israel accepted the conditions of the covenant; they made a personal commitment.

5. The agreement was sealed by blood; pointed to the blood of Christ.

III. The Tabernacle/Temple:

A. The building of the tabernacle established the institution of congregational worship.

B. Israelite worship reached its climax in the services of the temple.

C. The yearly feasts portrayed the Great Controversy.

1. The Passover--God's redemption from sin.

a. The Feast of the Unleavened Bread--Day after the Passover.

b. The Offering of the Firstfruits--Second day after the Passover.

2. The Feast of Trumpets--The proclamation of the Day of Atonement.

3. The Day of Atonement--The final judgement. 
4. The Feast of Tabernacles--The final feast which indicated the culmination of the Plan of Salvation.

IV. The Synagogue:

A. Was established after the Exile to Babylon.

B. Became the center of Jewish activity.

C. The main emphasis was not sacrifice, but to focus upon the Word of God and prayer.

D. In the Jewish worship of the New Testament the synagogue complemented the services of the temple. 
CHAPTER 4

\section{THE NEW TESTAMENT AND WORSHIP}

I. The study of worship in the New Testament era can be somewhat frustrating and difficult because the Bible does not give a major outline of the worship practices in the Apostolic Church.

A. "There is no single highly developed statement on worship in the New Testament." Robert Webber, Worship Old and New, 41.

B. "True, that church has left us no liturgy. That in itself is significant. We are not asked to copy a liturgy but to emulate a spiritual pattern. This pattern was one of simplicity, of directness, of Spirit-filled preaching, of lay participation, of free prayer, of spontaneity. It was not mysterious, formal, ritualistic, priestly, or highly structured. It was the worship of simple, dedicated people who believed completely in Christ and who loved to express their adoration to Him."

Norval F. Pease, And Worship Him, 47, 48.

II. New Testament worship continued the two basic Jewish services:

A. The temple. However, the temple lost its significance as the Christians moved away from Jerusalem.

B. The synagogue, where the focus was the Word of God.

C. Worship in the Apostolic age focused upon Jesus Christ as the visible word of God.

III. Acts 2:42--The early church members devoted themselves to:
A. The apostles' teaching.
B. The fellowship. 
C. The breaking of bread.

D. Prayer.

E. Acts 2:47--The Lord added to their number daily, those who were being saved.

IV. 1 Corinthians 12--14-Paul calls for everything in worship to be done in an orderly way.

V. Revelation 4 and 5:

A. Worship is given to the One on the throne--God is worshiped as the Creator.

B. Worship is also given to the Lamb that appeared as if it had been slain-God, through Jesus Christ, is worshiped as the Redeemer.

C. All of God's creation bows in homage to the One on the throne and to the Lamb.

VI. It is not the form of the New Testament worship we must recapture, but the spirit. 


\section{A MESSAGE FROM ELLEN WHITE . . .}

"Not by seeking a holy mountain or a sacred temple are men brought into communion with heaven. Religion is not to be confined to external forms and ceremonies. The religion that comes from God is the only religion that will lead to God. In order to serve Him aright, we must be born of the divine Spirit. This will purify the heart and renew the mind giving us a new capacity for knowing and loving God. It will give us a willing obedience to all His requirements. This is true worship. It is the fruit of the working of the Holy Spirit. By the Spirit every sincere prayer is indited, and such prayer is acceptable to God. Wherever a soul reaches out after God, there the Spirit's working is manifest, and God will reveal Himself to that soul. For such worshipers He is seeking. He waits to receive them, and to make them His sons and daughters."

The Desire of Ages, 189. 
CHAPTER 5

BAPTISM AND THE LORD'S SUPPER

THIS PAGE IS PROVIDED FOR NOTES ON THE PRESENTATION.

NOTES ON BAPTISM:

NOTES ON THE LORD'S SUPPER: 


\section{CHAPTER 6}

\section{WORSHIP IN THE EARLY CHURCH}

I. The Second Century A. D.:

A. There are very few literary sources of information concerning the development of Christian worship in the early centuries. There are strictly no liturgical manuals or texts.

B. Letter of Pliny, Roman governor of Bithynia in Asia Minor, to the Emperor Trajan, written about $112 \mathrm{~A}$. D.

1. "They affirmed, however, the whole of their guilt, or their error, was, that they were in the habit of meeting on a certain fixed day before it was light, when they sang in alternate verses a hymn to Christ, as to a god, and bound themselves by a solemn oath, not to any wicked deeds, but never to commit any fraud, theft, or adultery, never to falsify their word, nor deny a trust when they should be called upon to deliver it up; after which it was their custom to separate, and then to reassemble to partake of food--but food of an ordinary and innocent kind."

C. The Didache--An early church manual:

1. Baptism-"Concerning baptism, baptise thus: Having first rehearsed all these things, baptise in the Name of the Father and of the Son and of the Holy Spirit, in running water; but if thou hast no running water, baptise in other water, and if thou canst not in cold, than in warm. But if thou hast neither, pour water three times on the head in the Name of the Father, Son, and Holy Spirit."

2. Fasting--Christians were told to fast on Wednesdays and Fridays, and to repeat the Lord's Prayer three times a day.

3. The Lord's Supper-"And concerning the Eucharist, hold the Eucharist this: First concerning the Cup, 'We give thanks to thee, 
our Father, for the Holy Vine of David thy child, which thou didst make known to us through Jesus thy child; to thee be glory forever.' And concerning the broken bread: 'We give thanks to thee, our Father, for the life and the knowledge which thou didst make known to us through Jesus thy child. To thee be glory forever. As this broken bread was scattered upon the mountains, but was brought together and became one, so let thy Church be gathered together from the ends of the earth into thy kingdom, for thine is the glory and the power through Jesus Christ forever.' But let none eat or drink of the Eucharist except those who have been baptised in the Lord's Name."

4. NOTE: "Such prayers and formulas, used within a half century of the apostles, have a different ring from that of the New Testament. Christian leaders were now being told what they should say and what they should pray."

Norval F. Pease, And Worship Him, 28

D. Justin Martyr's First Apology, written around 140 A. D.:

1. The Reading of the Scripture-" On the day which is called Sunday we have a common assembly of all who live in the cities or in the outlying districts, and the memoirs of the Apostles or the writings of the Prophets are read, as long as there is time."

2. The Address of the President-"Then, when the reader has finished, the president of the assembly verbally admonishes and invites all to imitate such examples of virtue."

3. The Prayer-"Then we all stand up together and offer up our prayers, and as we have said before, after we finish our prayers, bread and wine and water are presented."

4. Thanksgiving and Amen of the people-"He who presides likewise offers up prayers and thanksgivings, to the best of his ability, and the people express their approval by saying 'Amen.'"

5. Distribution of the bread and the wine-"The Eucharistic elements are distributed and consumed by those present, and to those who are absent they are sent through the deacons."

6. Collection for the Poor-"The wealthy, if they wish, contribute whatever they desire, and the collection is placed in the custody of 
the president. [With it] he helps the orphans and widows, those who are needy because of sickness or any other reason, and the captives and strangers in our midst; in short, he takes care of all those in need."

7. "We assemble in common on Sunday, because this is the first day, on which God created the world and light, and because Jesus Christ our Savior on the same day rose from the dead and appeared to his disciples."

II. Summary: It was during this period of history that the church began to lose the simplicity of worship that it had been characterized by. Ritual and form started to creep into the practices of worship. These practices set the foundation for the major worship excesses and corruption that reached the pinnacle during the Middle Ages. 


\section{CHAPTER 7}

\section{WORSHIP IN THE MIDDLE AGES}

I. Worship took on an aura of Mystery:

A. The idea of worship as mystery has its origin in the mistaken usage of ceremonial forms and symbols, which took the place of the substance. These in themselves are not wrong--they are the means through which worship is conducted. However, when ceremonial forms become an end rather than a means they assume a cultic character and tend to replace the message they bear.

B. During the Constantinian era the church converted many pagan festivals and customs and invested them with Christian meaning.

C. Language--Even though the Church was established into many other countries with different languages, in the Western world the service was still in Latin, which most did not understand. In the Eastern Christian world Greek and other languages (such as Old Church Slavonic) were used.

D. The church distanced itself from the people by viewing itself as a hierarchical institution, instead of a body. The church became the means of bringing salvation to the people. The Lord's Supper (Eucharist) became the medium of salvation.

E. In the ninth century Paschasius Radbertus proposed a view of the presence of Jesus in the Mass by virtue of the miraculous change that occurred in the bread and the wine. This laid the groundwork for the doctrine of transubstantiation that became dogma at the Fourth Lateran Council in 1215.

F. A major result of the mystical view of worship is that the Mass became an epiphany of God. An overemphasis on the action of God in the Mass tended to overshadow the corporate action of the people in worship. The 
Mass assumed the character of a sacred drama that was played out by the clergy while the people watched.

G. Mystery--In many instances the mystery was turned into a superstition and the real meaning of worship was lost to both clergy and the people alike.

Robert Webber, Worship Old and New, 66-71.

II. Worship characteristics in the Middle Ages:

A. Men and women were denied the right of individual approach to God.

B. The Mass came to be regarded as an objective sacrifice repeating or continuing the work of Calvary. It was believed that at the consecration of the elements the bread and wine were miraculously transformed into the actual body and blood of Christ (transubstantiation), to be offered anew in the Mass. No longer was the occasion that of a simple supper, symbolic of the fellowship of the believers with their risen Lord and with one another. The supper had developed into a dramatic spectacle in which the worshipers were spectators rather than participators. Instead of weekly Communion the laity eventually partook only once a year.

C. The Scriptures were practically inaccessible to the people.

D. The sermon fell into serious decline, and moral instruction all but disappeared in a majority of congregations.

E. Congregational singing was discontinued.

F. Worship was no longer conducted by the leader facing the people from behind the table, as was the custom in the beginning. The table had become an altar set against the wall of the apse, the priest performing his liturgical acts facing the altar and with his back to the people.

G. The service was everywhere said in Latin, an alien tongue.

H. The people were exploited by paid masses and indulgences. Prayers for the dead became important, and a price was exacted for their repetition.

I. "Since only a priest could offer sacrifice, the prestige of the priesthood was inordinately enhanced. It also happened, moreover, that priests, victims of their own system, became mercenary and tyrannical, using their power to enrich the church at the expense of the spiritual welfare of the people."

James D. Robertson, Minister's Worship Handbook, 31-32. 
III. Other factors involving worship:
A. The monastic system--Pietism activity, led to an attitude of exclusiveness, and a holiness based upon individual righteous acts.
B. Church architecture was closely patterned after the basilica style.
C. Liturgy had definitely changed from a fluid state to one of fixed forms.
D. Universities were established to educate those for the priesthood, but most of the population remained illiterate.
E. Tradition took precedence over the Scriptures. 


\section{CHAPTER EIGHT}

\section{HOW THE REFORMERS CHANGED WORSHIP}

I. Although the Reformation was principally a reform of theology, it was inevitable that a reform of worship should result from it.

II. How the Reformers agreed:

A. The Protestants rejected the Mass because of the view that it repeated the sacrifice of Jesus on the cross.

1. Luther charged that the Mass had lost its original focus as a thanksgiving and had become a propitiation to please God.

2. People expected all types of benefits from the Mass--healings, releasing souls from purgatory, etc.

3. The Mass had lost its sense of communion because people did not even need to be present at the Mass--it could be said on their behalf.

4. The priest saying the Mass took the place of personal worship, and it became a legalistic way of buying salvation.

B. The Reformers rejected the doctrine of transubstantiation.

C. The Reformers insisted on the restoration of the Word [the Bible] to its proper place.

D. The Reformers agreed that worship should be in the vernacular, or the common language of the people.

E. The Reformers agreed upon the twofold structure of the Word and the sacrament. 
F. SUMMARY: Zwingli was the only Reformer who disagreed with the desire to return to the ancient structure of Word and sacrament. His emphasis was on the Word only. This position remained the most influential in the circles of Calvinism, and to the distress of John Calvin, quarterly communion, rather than weekly communion, became the standard in the churches most influenced by Calvinism. This influence extended through the English Puritans to the Baptists, Presbyterians, Congregationalists, and independents and spread through them to most of American Protestant Christianity.

III. Differences among the major Reformers:

A. Martin Luther:

1. Luther was the most conservative of the major Reformers.

2. He proposed that whatever is not forbidden by the Bible is allowed if in the judgement of the church it is deemed helpful.

3. Basic teachings:

a. There was the fellowship of Christians in and with the loving Word.

b. The Lord's Supper was the central service. Luther believed it should be celebrated daily throughout Christendom.

c. Luther believed in the real presence of Christ in the elements. This doctrine has been called the theory of consubstantiation.

d. The Mass was not a repetition of the death of Christ, as the Catholics claim, but Christians entered into His sacrifice, offering themselves up together with Christ.

e. Luther urged a Mass conducted in the vernacular. The first was celebrated without the vestment at Wittenberg in 1521.

f. Lutherans soon reverted to the old practice of the Roman Church, retaining the Latin where people could understand the language, most of the ceremonial lights, incense, and vestments. 
4. Luther did not go far enough in his reforms. However, it should be said in his behalf that he gave the people a more intelligible part in worship. There was greater emphasis upon the use of hymns. Liturgical uniformity was never a Lutheran ideal, for there were many variations and much creativity.

B. Ulrich Zwingli:

1. His approach to religion was more rational, and he sought for more simplicity and more moral reality in his worship.

2. Unlike Luther, Zwingli did not consider the Mass the norm of worship. It was stripped to its barest simplicity, and he believed four times per year was sufficient to receive the ordinances. To him it was simply a memorial.

3. He rejected symbols in worship and forbade all music except antiphonal recitation and canticles.

C. John Calvin:

1. Calvin was more moderate than Zwingli, more radical than Luther.

2. His philosophy was that anything which was not endorsed by Scripture should be abolished.

3. Calvin believed the Lord's Supper should be distributed monthly.

4. Calvin believed congregational singing of Psalms should be included in worship.

IV. A summary of Reformation worship:

A. The priesthood was abolished.

B. "Minister" was substituted for "priest."

C. Confession, absolution, penances, indulgences, and officiating at a sacrifice were eliminated.

D. Services were in the vernacular. 
E. Congregational participation increased, especially in hymn singing.

F. They generally discontinued usage of vestments.

G. They forbade prayers for the saints

H. They revived free prayer.

I. They shortened the service.

J. They introduced the central pulpit, with the Communion table in front of the pulpit.

K. Altars were turned into tables, and thus changed the interpretation of the Lord's Supper. 
CHAPTER 9

WORSHIP IN THE MODERN ERA

Protestant Traditions of Worship ${ }^{1}$

\begin{tabular}{|c|c|c|c|}
\hline Century & Left-wing & Central & Right-wing \\
\hline $16^{\text {th }}$ & Anabaptist & Reformed & Anglican, Lutheran \\
\hline $17^{\text {th }}$ & Quaker & Puritan & \\
\hline $18^{\text {th }}$ & & Methodist & \\
\hline $19^{\text {th }}$ & Frontier & & \\
\hline $20^{\text {th }}$ & Pentecostal & & \\
\hline
\end{tabular}

$20^{\text {th }}$-Century Worship Traditions ${ }^{2}$

\begin{tabular}{|c|c|c|}
\hline $\begin{array}{l}\text { Charismatic } \\
\text { [Left-wing] }\end{array}$ & $\begin{array}{c}\text { Evangelical/Reformed } \\
\text { [Central] }\end{array}$ & $\begin{array}{c}\text { Liturgical/Sacramental } \\
\text { [Right-wing] }\end{array}$ \\
\hline Five-fold ministry and government & Biblical foundation & Theology \\
\hline Power of the Spirit & Personal conversion & Orthodoxy \\
\hline Spiritual gifts & Evangelism and mission & Historic connection \\
\hline Charismatic worship & Pulpit-centered worship & Liturgical worship \\
\hline Kingdom & Personal holiness & Social action \\
\hline $\begin{array}{l}\text { Spiritual, organic, and functional } \\
\text { understanding of the church } \\
\text { (dynamic and informal) }\end{array}$ & $\begin{array}{l}\text { Biblical and reformational } \\
\text { understanding of the church } \\
\text { (pragmatic and rational) }\end{array}$ & $\begin{array}{l}\text { Incarnational understanding of the } \\
\text { church (based on theology, history, } \\
\text { and sacrament) }\end{array}$ \\
\hline
\end{tabular}

${ }^{1}$ James F. White, Introduction to Christian Worship, 43.

${ }^{2}$ Robert Webber, Worship Old and New, 133. 


\section{CHAPTER 10}

\section{MUSIC IN WORSHIP}

I. Music in the Bible--Old Testament:

A. Music was largely based upon experience:

1. Exodus 15:1-18--The Song of Moses.

2. Exodus 15:20, 21--The Song of Miriam.

B. Many of the Psalms were based upon personal experience.

C. 1 Samuel 18--David played for King Saul.

D. At its inauguration and dedication, instrumental music was used in the services of the temple.

E. 2 Chronicles 20--A hymn was used to encourage an army.

II. A history of music in the Christian church:

A. Early Church:

1. There are numerous hymns in the New Testament.

2. Some arise from a personal encounter with God:

a. Luke 1:42-45--John's mother, Elizabeth.

b. Luke 1:46-55--Mary.

c. Luke 1:68-79--John's father, Zechariah.

d. . Luke 2:29-32--Simeon. 
3. Possible New Testament examples of Christian hymns include:
a. Philippians 2:6-11.
b. Romans 11:33-35.
c. Colossians 1:15-20.
d. Ephesians 5:14.
e. 1 Corinthians 13 .

4. Hymns from the Book of Revelation are also songs of experience:
a. $\quad 4: 11 ; 5: 9-10 ; 11: 17-18--$ Songs of the 24 Elders.
b. 15:3-4--Song of Moses and the Lamb.

B. Middle Ages:

1. Clement of Alexandria

2. Ambrose of Milan--Wrote hymn texts for his congregation to sing.

3. Choirs of monks in the monasteries.

4. Plainsong--Gregorian Chant based upon the Psalter.

5. Later in this period polyphonic singing became prevalent.

6. Liturgical hymns for the Mass were composed; most in Latin, but some were in the vernacular.

C. The Reformation--The three major reformers had differing views about church music:

1. Luther re-instated the singing of congregational hymns.

2. Zwingli banned all music and destroyed organs.

3. Calvin restricted singing to the Psalms. 
D. Post-Reformation Era--Continued growth and revision:

1. J. S. Bach--Great choral, organ, and instrumental music.

2. G. F. Handel--Choral music in the oratorio style.

3. Hymn writers--Isaac Watts and Charles Wesley.

4. Gospel Song--Fanny Crosby.

5. Ralph Vaughan Williams--A British composer, he helped revive interest in English folk music and contributed to the improvement of music in the Church of England.

E. Modern Era--Many and varied trends:

1. $20^{\text {th }}$-Century "secular" forms of music such as jazz, rock, country, etc., have influenced contemporary Christian music.

2. In some congregations traditional instruments such as the piano and organ are being replaced by guitars and synthesizers.

3. The usage of hymnals is being replaced by displaying words to songs on screens.

4. Much of the contemporary music is subjective in nature.

III. Guidelines for religious music:

A. Theologically correct.

B. A balance between the objective and the subjective.

C. Adapted to the customs of the congregation.

D. Easy on the ears and the voice.

E. Music is to enhance the worship experience; it is not performance orientated. 


\section{CHAPTER 11}

\section{THE WORDS OF WORSHIP}

I. The Purpose of Preaching:

A. $\quad 2$ Timothy 4:2-5--Paul charged Timothy to Preach the Word.

B. Romans 10:14, 15--Preaching is God's primary method of proclaiming the Good News.

C. Matthew 4:17--Jesus preached a message of repentance, because the Kingdom of God was near.

D. Luke 24:32--The power of God's Word can make hearts "burn" like no other words can.

E. Acts 2:37--As Christ is lifted up listeners will be convicted of their need for repentance and cleansing.

II. Luther's Properties and Virtues of a good preacher:
A. Teach systematically.
B. Have a ready wit.
C. Be eloquent.
D. Have a good voice.
E. Have a good memory.
F. Know when to make an end.
G. Be sure of his doctrine. 
H. Venture and engage body and blood, wealth and honor in the Word.

I. Suffer self to be mocked and jeered of everyone.

III. The preaching experience is where:

A. A human instrument, the preacher, takes the divine Word, internalizes it, personalizes it, and shares its power and meaning with others. The Word is transmitted through human words.

B. The listeners hear the divine Words expressed in human thought and experiences.

C. The effect upon both the presenter and the listener is a deeper awareness of God's love through Jesus Christ and a desire for a deeper response demonstrated by loving and obedient service to Him.

IV. The usage of Scripture in worship:

A. The reading of Scripture should take a higher place in worship than it does in many congregations.

B. Scripture should be read on a systematic basis during the worship service. Passages could be chosen on the following:

1. Topical--According to the passage the minister is sharing with the congregation.

2. The church could use a lectionary, a book containing lists of Scripture to be read at worship services during the year.

C. The Scriptures should be treated respectfully during worship.

1. The reader should be well-prepared to share the passage with the congregation.

2. The reader should always treat the Bible in the dignified manner that it deserves.

V. Prayer and worship: 
A. Prayer is the breath of the soul.

B. Prayer is when the minister speaks to God on behalf of the people.

C. Types of prayer:

1. Invocation.

2. Offertory.

3. Pastoral Prayer:
a. Adoration.
b. Confession.
c. Petition.
d. Intercession.
e. Commitment.

D. Preparation for leading in prayer:

1. Pray first in private.

2. Consider the specific needs of the congregation.

3. Study Biblical prayers.

4. Study other prayers.

5. Outline and write out prayers.

6. Memorize portions of prayers.

7. Depend upon the Holy Spirit. 


\section{CHAPTER 12}

\section{THE FLOW OF WORSHIP}

\section{Longer Order of Worship}

Organ Prelude

Announcements

Choir and Ministers Enter

Doxology

Invocation

Scripture Reading

Hymn of Praise

Prayer

Anthem or Special Music

Offering

Hymn of Consecration

Sermon

Hymn

Benediction

Congregation Standing or Seated for a Few Moments of Silent Prayer

Organ Postlude

\section{Shorter Order of Worship}

Announcements

Hymn

Prayer

Offering

Hymn or Special Music

Sermon

Hymn

Benediction

Congregation Standing or Seated for Silent Prayer

Seventh-day Adventist Church Manual, $15^{\text {th }}$ Edition, 66. 


\title{
PROGRESSION OF MOODS FOR THE WORSHIP SERVICE
}

\author{
Methodist Church's Book of Worship for Church and Home
}

- Adoration

- Confession

- Affirmation

- Dedication

\section{Von Ogden Vogt--Modern Worship}

- Presentation: A vision of God as one offers himself for worship

- Penitence: A sense of humility in the divine presence which induces contrition, confession, and an appeal for pardon

- Exaltation: Which follows the consciousness of pardon expressed in praise

- Illumination: The soul receives light before setting forth upon the path of life anew

- Dedication or Consecration: The soul in truest consecration enlists for further service

\section{John Broadus}

- Recognition: Adoration or Vision--Turning thoughts toward God

Prelude; Call to Worship; Invocation

- Praise

- Confession

Hymns; Responsive Readings; Prayer

- Illumination

Prayer; Silent Prayer; Hymns

- Dedication

Scriptures; Sermon

Invitation; Benediction 


\section{VILLAGE CHURCH ORDER OF SERVICE}

Organ Prelude

Praise Time

Church Family Life

[Congregational Singing]

Welcome

[Announcements]

Hymn of Praise

Morning Prayer

Ministry Matters

Special Event

Offering

Offertory

Special Music

Scripture Reading

[Special Feature on Church Ministry]

[Baptism, Baby Dedication, etc.]

Hymn of Meditation

Sermon

Hymn of Dedication

Benediction

Organ Postlude

[Choir or Other Special] 


\section{CHAPTER 13}

\section{SEVENTH-DAY ADVENTIST WORSHIP}

I. Attention must be drawn to the Seventh-day Sabbath on which the congregation gathers for its worship celebration. The Sabbath may be publicized by the preached Word, but it should also be publicized in the other words that are spoken or sung in the order of service itself. The Sabbath reminds us of the past dimension of human existence, of our origin as sons and daughters of God. It is a symbol of our allegiance and dedication to God as our Creator and our Redeemer.

II. Attention must be drawn to the heavenly sanctuary and the ministry of Christ there, into which the worshiping congregation has entered by faith. Once again this should be publicized in the elements of the service. It makes us conscious of the present dimension of life, enabling us to see life here in the proper relationship to contemporary events in heaven.

III. Attention must be drawn to the second advent of Christ, which is the hope that the congregation takes with it into the world for the following six days. This too should be publicized in the order of service. It provides the future dimension of human existence.

IV. The Word of God must be preached. No Adventist worship service should take place without the public proclamation of the eternal Gospel, both law and grace. The Seventh-day Adventist Church has a mission of proclamation for which it dare not apologize. It is a message-oriented church, and therefore the communication of the message God has revealed for the end times must be a central feature.

V. The Eucharist, or holy communion, must be celebrated on a regular basis. In accordance with the Scriptures the gathered congregation must celebrate the sacramental word in communion by the eating of bread and the drinking of the unfermented juice of the grape. While the celebration of the communion is fixed by the Scripture, the details as to how it is to be done are not. For example, it is simply traditional for Adventists to bring the bread and the wine to the people in the distribution. An essential part of the service, however, is the washing of feet that is the major focus of John's account of the first communion service. It is in 
the foot washing that the priesthood of believers is able to function in a dramatic and symbolic way.

VI. Whether it takes place in the sanctuary or at a lake or river, baptism is also a major event in Adventist worship. As the symbolic act signifying burial and resurrection with Christ to a new life of faith and obedience, it can never be thought of as an incidental service. It should always take place in the presence of a congregation, or at least a portion of the congregation, as it is not a private affair. It signifies entrance into, and acceptance by, the family of God.

VII. Every worship service meets in the name of Jesus Christ, the Creator and Redeemer of the world, for, as He says, "Where two or three come together in my name, there I am with them" (Matthew 18:20, NIV).

--Adapted from C. Raymond Holmes, Sing a New Song!, 93, 94. 


\section{A GLOSSARY OF LITURGICAL TERMS}

Alleluia: (Hebrew, Hallelu-jah): An ascription to God from the ancient Hebrew liturgy.

Antiphon: A brief verse of a psalm or other text from Scripture which is sung or said.

Antiphonal: A method of singing between two parts of a choir, or between the choir and congregation.

Baptistry: That part of the church containing the tank for baptisms, and/or the tank itself.

Basilica: The early type of Christian church derived from the Roman hall used for legal or business purposes.' It is usually rectangular with columns extending the length of the nave with a narthex at the entrance end.

Benediction: A declaration, usually by the minister or presiding elder, that announces the grace and care of God for the believing congregation. Most frequently the Aaronic form is used from Numbers 6: "The Lord bless you and keep you, the Lord make His face to shine upon you, and be gracious to you, the Lord lift up His countenance upon you, and give you peace; In the name of the Father, and of the Son, and of the Holy Spirit." Other benedictions that are often used are 2 Cor 13:14; Heb 13:20-21; Jude 24-25.

Bidding Prayer. A form of prayer that consists of a series of petitions, each composed of a request to pray for something special, a moment of silence for individual prayers, and a verbal prayer by the minister that incorporates the prayers of the congregation.

Chorale: A form of melody for the support of hymns used in the worship service of the church. Developed most artistically by J. S. Bach (1685-1750) for the organ.

Closing Prayer. A prayer offered in lieu of a benediction by the minister or presiding elder. Usually containing words of thanks for blessings received in worship and petitions for grace to be the church in the world for the next six days.

Constants: Those parts of the order of service which do not vary in intent from week to week. 
Deacon: A member of the church ordained to various kinds of service in the church. During worship services deacons are in charge of receiving the offering and preparing for and assisting in the communion service.

Doxology: Means "blessing" and/or giving glory to God, such as: "Worthy is the lamb that was slain to receive power and riches and wisdom and might and honor and glory and blessing" ( $\operatorname{Rev} 5: 12$ ). Another form can be the final verse of a hymn in which praise to the three Persons of the Trinity is sung.

Elder: Ordained members of the local church who, together with the pastor, exercise spiritual leadership and oversight. Qualifications for the office of elder are high (see Exod 18:21; Acts 6:3; 1 Tim 3:7; 2 Tim 2:2; 1 Tim 3:1 13; 4:12-16; Titus 2:1-8).

Eucharist. A Greek term meaning "thanksgiving," which was the ancient name for the celebration of the holy communion. Holy communion is a significant act of celebration and thanksgiving by the church.

Eucharistic Prayer. The prayer, or prayers, offered by presiding elders prior to the distribution of the bread and wine in communion. It should be noted that it is the congregation that needs to be dedicated so that the body of Christ can be broken bread and poured-out wine for the sake of Christ in the world.

Exposition: A method of explaining passages of Scripture through sermonizing.

Introit: The liturgical hymn at the beginning of worship. It is the entrance hymn of the service and announces, not the entrance of the minister and elders onto the platform, but the entrance of the whole congregation into the presence of God.

Invocation: A calling upon God at the beginning of a service, usually in the form, "In the name of the Father, and of the Son, and of the Holy Spirit," or some similar form.

Litany: A form of intercessory prayer with a marked responsive character, sometimes incorporating the singing of a choir.

Liturgy: From a Greek word meaning a "public work." The whole system of the services, rites, and ceremonies of the church, whether formal or informal. Sometimes referred to as the order of service.

Narthex: That portion of the church building comprising the entrance area for the congregation. In the ancient basilica it was called the porch and was open to the outside. It has since become an enclosed area, part of the church building proper. 
Nave: That portion of the church building where the congregation sits during worship services.

Offertory: The action in the liturgy when the tithes and offerings are received from the congregation, usually accompanied by music by voice and/or instruments.

Occasional Service: A worship service of the congregation which does not occur on a regular basis, such as baptism, wedding, child dedication, and funeral.

Order of Service: Another term for liturgy, consisting of the ordered progression of worship activity to be engaged in by the congregation on any given occasion.

Opening Prayer: A prayer offered by the minister or elder in lieu of the invocation and inviting the presence of the Deity.

Ordinance: A term often used synonymously with "sacrament" to designate special celebrations such as the holy communion, foot washing, and baptism.

Penitential Psalms: Those psalms that express a penitential spirit, such as 6, 32, 38, 51, $102,130,143$. They are used when it is desirable to lead the congregation into a confession of sin.

Pericope: A Greek term meaning a lesson from Scripture that is appointed for reading in public worship, and/or the basis for the day's sermon.

Responsive Reading: A reading from the Psalms or other portions of Scripture, sometimes printed in a special section in the hymnal and usually read responsively.

Ritual: Another term used synonymously with "liturgy" and "order of service," referring to the action of a congregation in worship.

Rubrics: A liturgical term used in reference to directions established by the church, or a local congregation, for the conduct of the services of that church. The name comes from the red ink that was usually used to distinguish such rules from other texts. It is synonymous with the term "rules." (See White, Testimonies for the Church, Vol. 5, p. 491.)

Sabbath: The seventh day of the week, Saturday, which God has sanctified and set aside for rest from labor and for corporate worship. Not to be confused with Sunday, the first day of the week.

Sacrament: A rite or ordinance of the church in which the focus is upon the receiving of God's gifts of grace, rather than on the sacrificial or giving aspects of worship, such as 
holy communion and baptism. In this sense prayer and the Sabbath can be thought of as sacramental.

Sanctus: Means "holy;" a verbal expression declaring the holiness of God and the Son, such as, "Holy, holy, holy, is the Lord God, the Almighty, who was and who is and who is to come" $(\operatorname{Rev} 4: 8)$.

Sermon: The verbalizing of the Word of God, based on a biblical text or pericope.

Spirit of Prophecy: The term adopted by Seventh-day Adventists to refer to the counsel and the writings of Ellen G. White. (See Rev 19:10.)

Variants: Those parts of the order of service which vary in intent and/or content from week to week.

Vespers: A service for late afternoon or early evening. During the Reformation, vespers became the daily evening prayer service. Within the Seventh-day Adventist tradition it normally is held on Friday evening prior to sundown and/or on Saturday evening, and is used as a devotional and corporate means for opening and closing the Sabbath.

C. Raymond Holmes, Sing a New Song, 184-187. 


\section{BIBLIOGRAPHY}

Abernathy, William B. A New Look for Sunday Morning. Nashville: Abingdon Press, 1975 .

"Acts." SDA Bible Commentary. Ed. F. D. Nichol. Washington, DC: Review and Herald. Pub. Assn., 1953-57. 5:148, 149.

Ahlstrom, Sydney F. A Religious History of the American People. New Haven, CT: Yale University Press, 1972.

Allen, Ronald B., and Gordon L. Borrer. Worship: Rediscovering the Missing Jewel. Portland, OR: Multnomah Press, 1982.

Anderson, Paul. "Balancing Form and Freedom." Leadership 7 (Spring 1986): 24-33.

Andreason, M. L. Prayer. Mountain View, CA: Pacific Press Pub. Assn., 1957.

Blackwood, Andrew W. The Fine Art of Public Worship. New York: AbingdonCokesbury Press, 1939.

Bounds, E. M. Power Through Prayer. Springdale, PA: Whitaker House, 1982.

Broadus, John A. On the Preparation and Delivery of Sermons. San Francisco: Harper and Row, 1870.

Brown, Colin, ed. The New International Dictionary of New Testament Theology. 3 vols. Grand Rapids, MI: Zondervan Pub. House, 1967-1969.

Broyles, Anne. Meeting God Through Worship. Nashville: Abingdon Press, 1992.

Bruce, F. F. Commentary on the Book of Acts. Grand Rapids, MI: William B. Eerdmans Pub. Co., 1954.

Brunner, Peter. Worship in the Name of Jesus. St. Louis: Concordia Pub. House, 1968. 
Cabaniss, Allen. Pattern in Early Christian Worship. Macon, GA: Mercer University Press, 1989.

Christensen, James L. Don't Waste Your Time in Worship. Old Tappen, NJ: Fleming H. Revell Co., 1978.

Church Hymnal. Washington, DC: Review and Herald Pub. Assn., 1941.

Cox, James W. A Guide to Biblical Preaching. Nashville: Abingdon Press, 1976.

Crum, Milton. Manual on Preaching. Valley Forge, PA: Judson Press, 1977.

Cullman, Oscar. Early Christian Worship. Philadelphia: Westminster Press, 1953.

Davies, Horton. Christian Worship: Its History and Meaning. New York: Abingdon Press, 1957.

Davis, Henry Grady. Design for Preaching. Philadelphia: Fortress Press, 1958.

. Why We Worship. Philadelphia: Muhlenburg Press, 1961.

Dawn, Marva J. Reaching Out Without Dumbing Down: A Theology of Worship for the Turn-of-the-Century Culture. Grand Rapids, MI: William B. Eerdmans Pub. Co., 1995.

Delling, Gerhard. Worship in the New Testament. Philadelphia: Westminster Press, 1962.

Dodd, C. H. The Apostolic Preaching. Chicago: Willet, 1937.

Emurian, Ernest K. Famous Stories of Inspiring Hymns. Grand Rapids, MI: Baker Book House, 1956.

. Living Stories of Famous Hymns. Grand Rapids, MI: Baker Book House, 1955.

Erickson, Millard J., ed. The Living God: Readings in Christian Theology. Grand Rapids, MI: Baker Book House, 1973.

Evans, I. H. The Preacher and His Preaching. Washington, DC: Review and Herald Pub. Assn., 1938.

Fant, Clyde E. Preaching for Today. New York: Harper and Row, 1975.

"Genesis." Seventh-day Adventist Bible Commentary. Edited by F. D. Nichol. Washington, DC: Review and Herald Pub. Assn., 1953-57. 1:208. 
Hahn, Ferdinand. The Worship of the Early Church. Philadelphia: Fortress Press, 1973.

Hannum, Harold B. Let the People Sing. Washington, DC: Review and Herald Pub. Assn., 1981.

Music and Worship. Nashville: Southern Pub. Assn., 1969.

Hayford, Jack W. Worship His Majesty. Waco, TX: Word Books, 1987.

Hayford, Jack, John Killenger, and Howard Stevenson. Mastering Worship. Portland, OR: Multnomah Press, 1990.

Haynes, Carlyle B. The Divine Art of Preaching. Washington, DC: Review and Herald Pub. Assn., 1939.

Hess, Klaus. Latreuo. Dictionary of New Testament Theology. Edited by Colin Brown. Grand Rapids, MI: Zondervan Pub. House, 1971. 3:551-553.

Hoffer, Charles R. The Understanding of Music. Belmont, CA: Wordsworth Pub. Co., 1967.

Holmes, C. Raymond. "Authentic Adventist Worship." Ministry, October 1991, 13-16. It's a Two Way Street. Washington, DC: Review and Herald Pub. Assn., 1978. . The Last Word. Berrien Springs, MI: Andrews University Press, 1987. ."Searching for Genuine Adventist Worship," Adventists Affirm 5, no. 2 (Fall 1991): 29

. Sing a New Song. Berrien Springs, MI: Andrews University Press, 1984.

Hoon, Paul W. The Integrity of Worship. New York: Abingdon Press, 1971.

Janson, H. W., and Joseph Kerman. A History of Art and Music. New York: Harry N. Abrams, n.d.

Johnston, Robert M. "Congregational Worship in the New Testament and the Early Church." Unpublished manuscript. Andrews University, Berrien Springs, MI, n.d.

Jones, Cheslyn, Geoffrey Wainright, and Edward Yarnold, eds. The Study of Liturgy. New York: Oxford University Press, 1978.

Keil, C. F., and F. Delitzsch. Commentary on the Old Testament. 10 vols. Grand Rapids, MI: William B. Eerdmans Pub. Co, 1952. 
Ladd, George Elden. A Theology of the New Testament. Grand Rapids, MI: William B. Eerdmans Pub. Co., 1974.

LeMon, Cal. "Surviving Sunday Morning Innovations." Leadership 7 (Spring 1986): 8490.

Lewis, Ralph L., and Greg Lewis. Inductive Preaching. Westchester, IL: Crossway Books, 1983.

Lischer, Richard. A Theology of Preaching. Nashville: Abingdon Press, 1981.

Lloyd, Norman. The Golden Encyclopedia of Music. New York: Golden Press, 1968.

Martin, Linford Lee. The Challenge of the Empty Pew: A Pastor's Guide to Improved Church Attendance. Lincoln, NE: Church Resources Distribution Center, 1992.

Martin, Ralph P. Worship in the Early Church. Grand Rapids, MI: William B. Eerdmans Pub. Co., 1964.

Maxwell, C. Mervyn. Tell It to the World. Rev. ed. Boise, ID: Pacific Press Pub. Assn., 1977 ,

Maxwell, William D. An Outline of Christian Worship: Its Development and Forms. London: Oxford University Press, 1936.

Micks, Marianne H. The Future Present: The Phenomena of Christian Worship. New York: Seabury Press, 1970.

The Joy of Worship. Philadelphia: Westminster Press, 1982.

Morgan, G. Campbell. Preaching. Grand Rapids, MI: Baker Book House, 1974. The Ministry of the Word. New York: Fleming H. Revell Co., 1919.

Morris, Colin. The Word and the Words. New York: Abingdon Press, 1975.

Moule, C. D. F. Worship in the New Testament. Richmond, VA: John Knox Press, 1961.

Nix, James R. Early Advent Singing. Hagerstown, MD: Review and Herald Pub. Assn., 1994.

Palmer, Albert W. The Art of Conducting Public Worship. New York: Macmillan Co., 1946.

Paquier, Richard. Dynamics of Worship. Philadelphia: Fortress Press, 1967. 
Patterson, Ben. "Can Worship Leaders Worship?" Leadership 7 (Spring:1986), 34-38. . "Worship as Performance." Leadership 2 (Summer 1981): 49-52.

Pease, Norval F. And Worship Him. Nashville: Southern Pub. Assn., 1967.

"Psalms." Seventh-day Adventist Bible Commentary. Edited by F. D. Nichol. Washington, DC: Review and Herald Pub. Assn., 1953-57. 3:756.

Qualben, Lars P. A History of the Christian Church. New York: Thomas Nelson and Sons, 1933.

Randolph, David James. God's Party. New York: Abingdon Press, 1975.

Rayburn, Robert G. O Come, Let Us Worship. Grand Rapids, MI: Baker Book House, 1980.

Richards, H. M. S. Feed My Sheep. Washington, DC: Review and Herald Pub. Assn., 1958.

Robertson, James D. Minister's Worship Handbook. Grand Rapids, MI: Baker Book House, 1974.

Robinson, Haddon W. Biblical Preaching. Grand Rapids, MI: Baker Book House, 1980.

Rutz, James H. The Open Church. Auburn, ME: The Seedsowers, 1992.

Schaeffer, Francis A. How Should We Then Live? Old Tappen, NJ: Fleming H. Revell Co., 1976.

Schroder, Frederick W. Worship in the Reformed Tradition. Philadelphia: United Church Press, 1966.

Segler, Franklin M. Christian Worship: Its Theology and Practice. Rev. ed. Nashville: Broadman \& Holman Publishers, 1996.

Senn, Frank C. Christian Worship: Its Cultural Setting. Philadelphia: Fortress Press, 1983. . The Witness of the Worshiping Community: Liturgy and the Practice of Evangelism. New York: Paulist Press, 1993.

Seventh-day Adventists Believe .... Hagerstown, MD: Review and Herald Pub. Assn., 1988. 
Seventh-day Adventist Bible Dictionary. Edited by Siegfried H. Horn. Washington, DC: Review and Herald Pub. Assn., 1960. S.v. "Worship."

Seventh-day Adventist Church Manual. $15^{\text {th }}$ ed. Hagerstown, MD: Review and Herald Pub. Assn., 1995.

Seventh-day Adventist Hymnal. Washington, DC: Review and Herald Pub. Assn., 1985.

Sleeth, Ronald E. Persuasive Preaching. Berrien Springs, MI: Andrews University Press, 1956.

Sonne, I. "Synagogue." Interpreter's Dictionary of the Bible. Edited by G. A. Buttrick et al. Nashville: Abingdon Press, 1962. 4:477-491.

Stevenson, Robert M. Patterns of Protestant Church Music. Durham, NC: Duke University Press, 1953.

Stott, John R. W. Between Two Worlds. Grand Rapids, MI: William B. Eerdmans Pub. Co., 1982. Your Mind Matters. Downer's Grove, IL: InterVarsity Press, 1972.

Strong, Augustus Hopkins. Systematic Theology. 3 vols. Old Tappen, NJ: Fleming H. Revell Co., 1907.

Thompson, Alden. Inspiration. Hagerstown, MD: Review and Herald Pub. Assn., 1991.

Thompson, Brad, ed. Liturgies of the Western Church. Minneapolis: Augsburg Fortress, 1980 ,

Turner, R. Edward. Proclaiming the Word. Berrien Springs, MI: Andrews University Press, 1980.

Vitrano, Steven P. So You're Not a Preacher! Washington, DC: Review and Herald Pub. Assn., 1977.

Warren, Rick. The Purpose Driven Church. Grand Rapids, MI: Zondervan Pub. House, 1995.

Watson, David. I Believe in the Church. Grand Rapids, MI: William B. Eerdmans Pub. Co., 1978.

Webber, Robert E. Worship Is a Verb. Rev. ed. Nashville: Abbott Martyn, 1992. 
Webber, Robert E. Worship Old and New. Rev. ed. Grand Rapids, MI: Zondervan Pub. House, 1994.

Webster's Ninth New Collegiate Dictionary. 1984. S.v. "enmity."

Weinmann, Karl. History of Church Music. Westport, CT: Greenwood Press, 1910.

Westerhoff, John, and William Willimon. Liturgy and Learning Through the Life Cycle. New York: Seabury, 1980.

White, Ellen G. The Acts of the Apostles. Mountain View, CA: Pacific Press Pub. Assn., 1911.

. The Desire of Ages. Mountain View, CA: Pacific Press Pub. Assn., 1898.

. Evangelism. Washington, DC: Review and Herald Pub. Assn., 1946.

. The Great Controversy. Mountain View, CA: Pacific Press Pub. Assn., 1911.

. Patriarchs and Prophets. Mountain View, CA: Pacific Press Pub. Assn., 1958.

Steps to Christ. Mountain View, CA: Pacific Press Pub. Assn., 1956.

Testimonies for the Church. 9 vols. Mountain View, CA: Pacific Press Pub. Assn., 1948.

White, James F. A Brief History of Christian Worship. Nashville: Abingdon Press, 1993. 1977.

Christian Worship in North America. Collegeville, MN: The Liturgical Press, Christian Worship in Transition. Nashville: Abingdon Press, 1976.

. Introduction to Christian Worship. Rev. ed. Nashville: Abingdon Press, 1990. New Forms of Worship. Nashville: Abingdon Press, 1971.

White, James S. "Reflections by the Way." Review and Herald, Oct. 7, 1875, 4.

White, Lyla. "Worshipers Make the Worship Service Work." Leadership 2 (Summer 1981): 88-91.

Wiersbe, Warren W. Real Worship: It Will Transform Your Life. Nashville: Thomas Nelson Publishers, 1986. 


\section{VITA}

Neal Maynard Matson was born in Yakima, Washington, in 1950. He remained a resident of the Pacific Northwest, being raised on the family fruit ranch near Yakima. In 1972 he received his Bachelor of Arts degree from Walla Walla College. His major was in modern languages, having spent his junior year of college at Seminar Marienhöhe in Darmstadt, Germany. After graduation he spent two years at Walla Walla College doing post-graduate study in theology in preparation for the pastoral ministry. He entered ministry in the Oregon Conference in 1974 . He received his Master of Divinity degree from Andrew University in 1978. He has pastored churches in the Oregon and Upper Columbia Conference, and currently is Pastor of Evangelism at the Village Church in College Place, Washington. He is married to Dianne Bohlman Matson and has two daughters, Lisa Matson Blackwelder, and Debra. 